\title{
BH3-mimetics: recent developments in cancer therapy
}

\author{
Paul A. Townsend ${ }^{1,2,3^{*}}$, Maria V. Kozhevnikova ${ }^{1,2}$, Olivier N. F. Cexus ${ }^{1}$, Andrey A. Zamyatnin Jr ${ }^{1,2,4,5}$ and \\ Surinder M. Soond ${ }^{1,2^{*}}$ (D)
}

\begin{abstract}
The hopeful outcomes from 30 years of research in $\mathrm{BH} 3$-mimetics have indeed served a number of solid paradigms for targeting intermediates from the apoptosis pathway in a variety of diseased states. Not only have such rational approaches in drug design yielded several key therapeutics, such outputs have also offered insights into the integrated mechanistic aspects of basic and clinical research at the genetics level for the future. In no other area of medical research have the effects of such work been felt, than in cancer research, through targeting the BAX-BCl-2 protein-protein interactions. With these promising outputs in mind, several mimetics, and their potential therapeutic applications, have also been developed for several other pathological conditions, such as cardiovascular disease and tissue fibrosis, thus highlighting the universal importance of the intrinsic arm of the apoptosis pathway and its input to general tissue homeostasis. Considering such recent developments, and in a field that has generated so much scientific interest, we take stock of how the broadening area of BH3-mimetics has developed and diversified, with a focus on their uses in single and combined cancer treatment regimens and recently explored therapeutic delivery methods that may aid the development of future therapeutics of this nature.
\end{abstract}

Keywords: Apoptosis, BH-3 mimetics, PUMA-mimetics, Smac-mimetics, BCl-xL-mimetics, Noxa-mimetics, Mcl1mimetics, Nanoparticles

\section{Background}

Harnessing the potential of apoptosis, as a strategic approach for the eradication of cancer cells, has been an area of intense activity over the last 30 years, ranging from the implementation of death inducing ligands and therapeutics, to engineering synergistic chemical antagonists [1, 2]. What originally started as research aimed at unveiling the mechanistic input of extrinsic and intrinsic signaling pathways in cell demise, has indeed developed towards how such pathways can be therapeutically exploited as the findings have transitioned from a basic- to applied- research setting. Underpinning such developments have unambiguously relied on defining an

\footnotetext{
*Correspondence: p.townsend@surrey.ac.uk; s.soond@surrey.ac.uk

${ }^{1}$ University of Surrey, Guildford, UK

Full list of author information is available at the end of the article
}

ever-growing number of molecular signaling networks and their detailed regulatory crosstalk in defining potential axes of regulation that may be amenable for therapeutic intervention [3].

Herein, one critical regulatory event central to triggering apoptosis is the activation of Mitochondrial Outer Membrane Polarization (MOMP) and is the cornerstone of intrinsic pathway activation. How this is achieved at the molecular level, and what factors regulate the thresholds that exist in achieving MOMP, thereby predisposing cells to undergo apoptosis, has been the basis of many excellent studies that have either overlapped or converged on the importance of the Bcl-2 homology (BH) -domain containing proteins [4].

Briefly, the Bcl-2 proteins can be broadly categorized as acting in either a pro-apoptotic or anti-apoptotic manner. Whilst these groups act directly in driving or diminishing original author(s) and the source, provide a link to the Creative Commons licence, and indicate if changes were made. The images or other third party material in this article are included in the article's Creative Commons licence, unless indicated otherwise in a credit line to the material. If material is not included in the article's Creative Commons licence and your intended use is not permitted by statutory regulation or exceeds the permitted use, you will need to obtain permission directly from the copyright holder. To view a copy of this licence, visit http://creativecommons.org/licenses/by/4.0/. The Creative Commons Public Domain Dedication waiver (http://creativeco mmons.org/publicdomain/zero/1.0/) applies to the data made available in this article, unless otherwise stated in a credit line to the data. 
apoptosis, a third group of proteins, which are functionally and structurally unique, and when over-expressed can sensitize cells to biochemical cues that induce apoptosis, are the BH3-only proteins (or sensitizer proteins). From these three groups, the BAX (pro-apoptotic) and Bcl-2, Bcl-xL or Mcl1 (anti-apoptotic) proteins have gained the most attention over the recent decades, based on their deregulated expression, significance in the development of a number of cancers and their responsiveness to therapeutics [5]. From these, the importance of BAX protein deregulation in cancer development can stem from the loss-of-function genetic frame-shift mutations, which contribute to the prevalence of a number of solid tumors and leukemias [6-8]. Conversely, in the instance of the Bcl-2 and Bcl-xL anti-apoptotic proteins, their genetically deregulated-over-expression can give rise to similar malignancies, such as B-cell lymphoma, prostate cancer, non-small cell lung cancer, Acute lymphoblastic leukaemia and breast cancer [9-12].

As an alternative regulatory mechanism, protein subcellular localization and the coordinated manner in which $\mathrm{Bcl}-2$ protein family members can be regulated by factors from the nucleus, lysosome and mitochondria, has also taken on greater significance over the recent years [13]. Synergistically, the structural composition of the Bcl-2 proteins has unveiled how such proteins come to reside at specific subcellular compartments, and whether each member is regulated by other group members of this family through protein-protein interactions (Table 1) [14].

In large, the $\mathrm{Bcl}-2$ proteins are composed of conserved BH1-4 domains and in some instances a transmembrane domain (Fig. 1) [4]. Here, the key structural component of intrinsic importance, which is present in all of the pro-apoptotic Bcl-2 family protein members, is unquestionably the BH3 domain, which is a structure composed of $\sim 15$ amino acids from $\alpha$-helix 2 , and which interacts with the hydrophobic pocket structure formed by $\alpha$-helices 2-5 of the anti-apoptosis proteins, such as Bcl-2 protein (Fig. 1) [15].

Mechanistically, the interplay between all three groups of proteins, based on their relative abundance in the presence of biochemical activation cues, determine whether the two key intermediates BAX and BAK successfully mediate the formation of a Mitochondrial Pore Complex (MPC), denoted by enlarged mitochondrial cristae and the ultimate release of cytochrome $\mathrm{c}$ as a prerequisite to caspases $-3,-7$ and -9 activation and finally followed by DNA fragmentation $[16,17]$. Part of this mechanism incorporates the complex regulatory input from TP53 activation and the key mitochondrial proteins NOXA, PUMA and Smac/DIABLO $[18,19]$. As a relatively weak and indirect activator of apoptosis, BH3-only NOXA can bind (and inhibit) the anti-apoptotic regulators Mcl1 and $\mathrm{Bcl}-2 \mathrm{~A} 1$, thus preventing their suppression of BAX- and BAK- protein activation [20-22]. Alternatively, NOXA has also been reported to bind BAX and activate apoptosis in the absence of a BIM, BID and Bcl-xL expression-dependent manner, thereby regulating apoptosis directly [23, 24]. Similarly, BH3-only PUMA can induce apoptosis through the direct activation of BAX or BAK [25]. As a negative regulator of apoptosis, Mcl1 has been widely reported as being overexpressed in a number of cancers such as lung and breast [26, 27], and which can be destabilized by NOXA, through the ubiquitination pathway $[28,29]$. As an integral regulator of apoptosis, PUMA can also mediate activation of apoptosis through a direct association with Mcl1, that is reversible

Table 1 The Bcl-2 protein family members can be sub-grouped into pro-apoptotic (Pro-), anti-apoptotic (Anti-) and sensitizer (Sen-) members, which originate from distinct genetic loci and encode proteins of varying amino-acid (aa) length and molecular weight (in kilodaltons, $\mathrm{kDa}$ ). Each member can be localized in the cytoplasm (C), mitochondria (M), endoplasmic reticulum (ER) or the nucleus (N) and can be regulated through its interaction with other protein family members through protein-protein interactions

\begin{tabular}{|c|c|c|c|c|c|}
\hline Protein & Apoptosis & Gene & Size (kDa) & Location & Protein Partners \\
\hline BAX & Pro- & $19 q 13.33$ & 192aa (21.18) & $C, M, N, E R$ & BAK, BCl-2,BCl-xL,MCl1, BID, BIM, NOXA \\
\hline BAK & Pro- & $6 p 21.31$ & 211 aа $(23.40)$ & M & $\mathrm{BAX}, \mathrm{BCl}-2, \mathrm{BCl}-\mathrm{xL}, \mathrm{MCl} 1, \mathrm{BID}$ \\
\hline $\mathrm{Bcl}-2$ & Anti- & $18 q 21.33$ & 239aа (26.00) & $C, M, N, E R$ & BAX, BAK, BCl-xL, BID, BIM, BAD, PUMA, NOXA \\
\hline $\mathrm{Bcl}-\mathrm{xL}$ & Anti- & $20 q 11.21$ & 233aа (26.04) & $M, C$ & BAX, BAK, BCl-2, BID, BIM BAD, PUMA \\
\hline Mcl1 & Anti- & $1 \mathrm{q} 21.20$ & 350aa (37.33) & $C, M, N$ & BAX, BAK, BID, BIM, PUMA, NOXA \\
\hline BID & Pro-/Sen- & $22 q 11.21$ & 195aa (21.99) & $C, M$ & $\mathrm{BAX}, \mathrm{BAK}, \mathrm{BCl}-2, \mathrm{BCl}-\mathrm{xL}, \mathrm{Mcl} 1$ \\
\hline BIM & Pro-/Sen- & $2 q 13.00$ & 198aa (22.17) & $C, M$ & $\mathrm{BAX}, \mathrm{BCl}-2, \mathrm{BCl}-\mathrm{xL}, \mathrm{Mcl} 1$ \\
\hline BAD & Pro-/Sen- & $11 q 13.10$ & 168aa (18.39) & $C, M$ & $\mathrm{BCl}-2, \mathrm{BCl}-\mathrm{xL}$ \\
\hline PUMA & Pro-/Sen- & $19 q 13.32$ & 193aa (20.53) & $M$ & $\mathrm{BCl}-2, \mathrm{BCl}-\mathrm{xL}, \mathrm{MCl} 1$ \\
\hline NOXA & Pro-/Sen- & $9 q 34.30$ & 476aa (50.93) & $C, M, N$ & $\mathrm{BAX}, \mathrm{BCl}-2, \mathrm{MCl} 1$ \\
\hline SMAC & Pro-/Sen- & $12 q 24.31$ & 239aa (27.13) & $C, M$ & xIAP1 \\
\hline
\end{tabular}




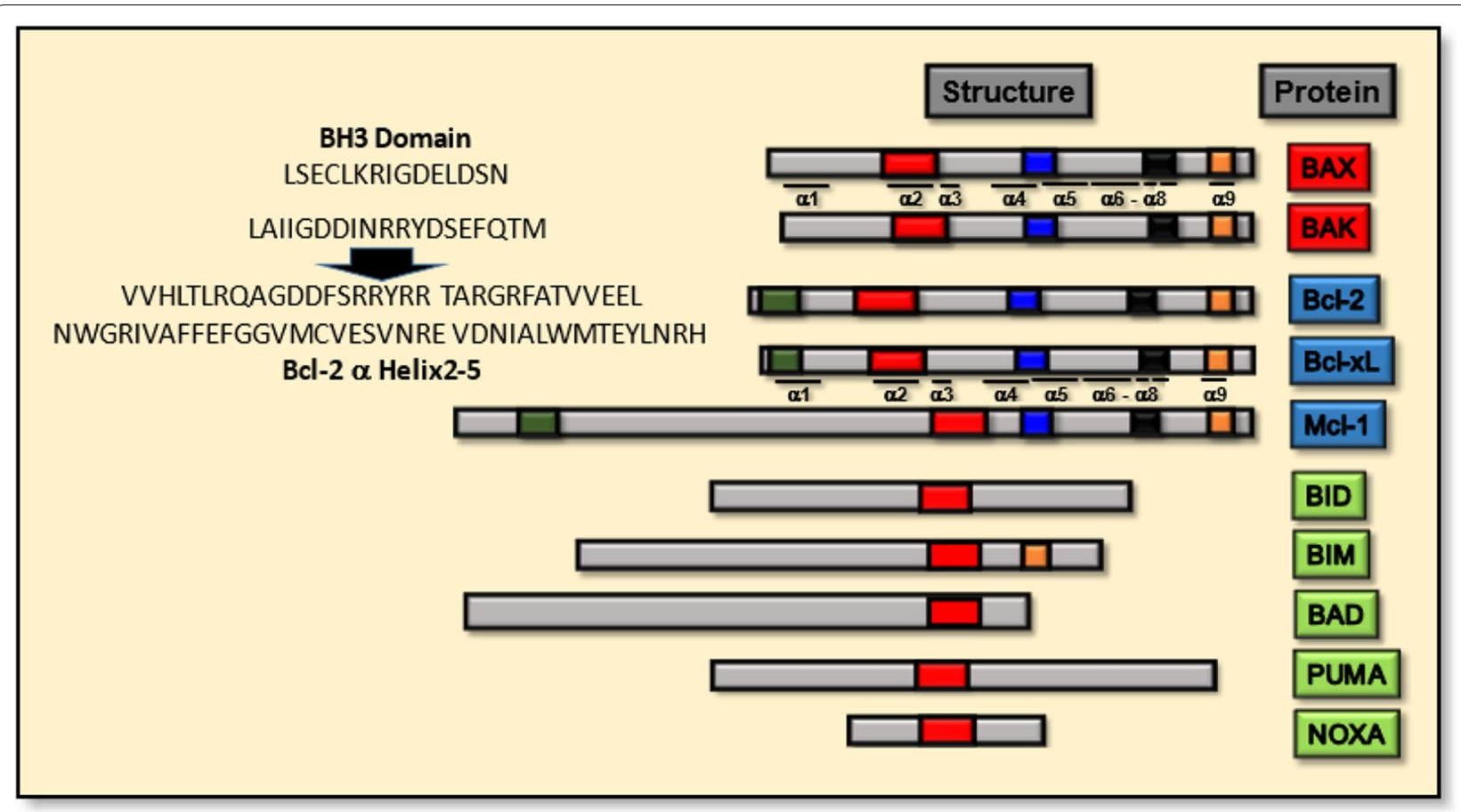

Fig. 1 The BH- and helical- domain composition of selected Bcl-2 family pro-apoptotic (red boxes), anti-apoptotic (blue boxes) and BH3-only (green boxes) members. The amino acid sequences of the human BH3-domains from BAX and BAK are highlighted (top left), below which are shown the amino acid sequences of the alpha helices $2-5$ from the human $\mathrm{BCl}-2$ protein. For each of the proteins, the transmembrane domain is highlighted in orange and $\mathrm{BH} 1-4$ domains are respectively highlighted in blue, black, red and green for the relevant proteins

upon NOXA expression (through it binding Mcl1), thus releasing PUMA by a 'catch and release' mechanism [30, 31]. Consequently, from a therapeutic standpoint, Mcl1 expression and regulation have taken on increasing levels of importance, particularly from the contribution they make in offering drug resistance to several cancer therapeutics [32-35]. Like NOXA [36] and PUMA [37, 38], Smac/DIABLO [39] is also resident on the cytoplasmic face of the MOM, and which uniquely allows it to fulfill its role as a positive activator of caspases, through it binding and inhibiting the Inhibitor of Apoptosis Proteins (IAPs), from the extrinsic and intrinsic arms of the apoptosis pathway [40].

Collectively, the functional significance of such a small handful of regulatory proteins on cell fate cannot be underplayed, as neither can their mechanistic regulation. While some facets of the latter may be steeped in controversy, many aspects of the BH3-domain containing proteins (and their regulation) have nevertheless been fully harnessed throughout the initial formulation of BH3-mimetics, the emerging Smac-mimetics or the Mcl-inhibitors, and their applications as potential cancer therapeutics, thereafter (Fig. 2).

The principles of BH3-mimetics are mechanistically founded on disrupting the interaction of the pro-apoptotic BH3 domain with the hydrophobic pocket of the anti-apoptotic Bcl-2 proteins (such as Bcl-2, Bcl-xL or Mcl1), thus permitting oligomerized $\mathrm{BAX}$ (or BAK) to form the MCP [1]. While this approach is largely dependent on labor-intensive rational therapeutic design strategies, the functional significance of such an approach is rewarded with yielding antagonists that have high efficacy, with demonstrated effectiveness at nano-Molar (nM) concentrations, and which have the potential to be used as either single- or combined- therapeutics [5]. Whilst the founding members of the BH3-mimetic drugs did exhibit multiple protein targets, the subsequent preclinical studies that have arisen from such findings have identified a number of additional protein targets. Consequently, when targeted collectively with single therapeutics using combined therapeutic regimens at the pre-clinical and clinical levels, such therapeutics are showing a very high level of effectiveness and generating a growing level of interest in how drugs of this nature can be developed further for greater efficacy.

Synonymously, as progress in therapeutic development has come into fruition, so have the delivery methods that can be utilized for efficient drug delivery to offer maximum effects. Of late, such approaches include the use of self-assembling nanofibers and 


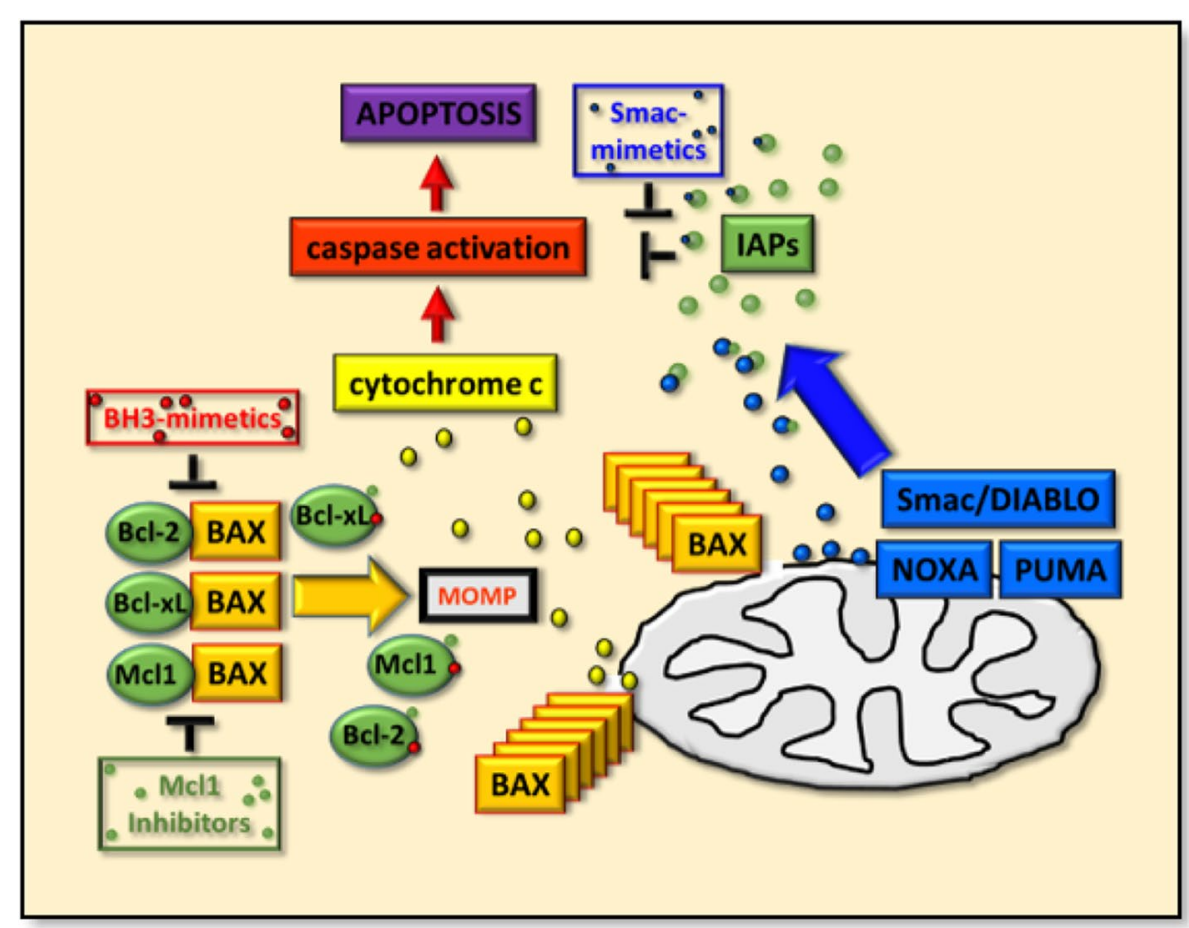

Fig. 2 The regulation of apoptosis by the BAX protein through mitochondrial outer membrane permeabilization (MOMP), and the modulation of this key steps by therapeutics. Key negative regulator BCl-2, BCl-xL and Mcl1 proteins (solid oval green boxes) for BAX (solid orange box) and their apoptosis inducing effects by cytochrome $\mathrm{c}$ release (solid yellow box and circles), caspase protein activation (solid red box) and apoptosis (solid purple box) are shown. The mimetics/inhibitors that can target anti-/pro-apoptotic protein interactions are highlighted as BH3-mimetics (outlined red box, red dots) and Mcl1 inhibitors (outlined green box, green dots), which either induce apoptosis of cells as mono-therapeutics or sensitize them to such effects during combined therapeutic targeting. The blue solid boxes (and small circles) highlight mitochondrial Smac/ DIABLO, NOXA and PUMA, which bind the Inhibitor of Apoptosis Proteins (small green circles, IAPs) and the interactions of which can be inhibited by Smac-mimetics (blue outlined box and blue dots)

micelles. The importance of such emerging approaches is highlighted by them offering greater scope in permitting the development and delivery of novel therapeutics that may otherwise be limited by their solubility and availability to cancer cells.

As seen in the context of most cancer-related diseases, the development of BH3-mimetics has been driven by them inducing cell death through apoptosis, a morphologically distinct form of death followed by phagocytosis [41]. Herein, we highlight the importance of this therapeutic paradigm, how it has evolved over time through it being applied in targeting additional key regulatory intermediates from the intrinsic apoptosis pathway. As this has given rise to a number of other potential therapeutics, we describe them in the context of how effective they are as single- or combined-therapeutics in preclinical and clinical models. In doing so, we also address the challenges that have arisen, and how some of them can be addressed through key emerging delivery and targeting approaches, so that novel therapeutics of this nature can be given greater effect for the future.

\section{Main text}

\section{Basic research and mimetics: a rational drug design} strategy

With the contextual origins of BH3-mimetics laying with certain intrinsic pathway intermediate proteins of apoptosis, several approaches have been adopted to develop such therapeutics through specific aspects of rational drug design. For such purposes, the $\mathrm{BAX} / \mathrm{Bcl}-2$ regulatory axis has primarily served as a strong foundation to build upon, with particular focus between the 15-amino acid BH3-domain spanning $\alpha$-helix 2 of BAX [15], and the hydrophobic pocket of Bcl-2 (spanning $\alpha$-helices 2-5, Fig. 1), for the development of small peptides- and small molecule- inhibitors (SMIs). In furthering such developments, the categorization of genuine mimetics through 'BH3 profiling', and whether the potency of candidate agents can induce apoptosis and reduce cell viability in the absence of BAK or BAK expression has also offered good leads in defining therapeutic -authenticity, -specificity and any off-target effects [42-44]. Based on such principles, what has arisen is the diversification of 
potential antagonists (in both manner and form) and their on-going development and applications in modulating the apoptosis pathway.

Classically, BH3-mimetics have incorporated engineered peptide inhibitors derived from the $\mathrm{BH} 3$ domain of the pro-apoptotic activators or sensitizer proteins and designed to bind the hydrophobic groove of their cognate anti-apoptotic proteins [45-47]. Such, unprecedented developments dispelled the belief that such protein-protein targets were 'undruggable' at that juncture. While additional criteria of importance included high-affinity binding to targets (within $\mathrm{nM}$ ranges) and a dependency on BAK or BAX induced apoptosis [48], some therapeutic peptides were observed to be toxic, unstable and where penetrability was relatively low [49]. However, some candidates emerged to have great potential in acting as apoptosis inducers or sensitizers, either as single agents or in a combined therapeutic approach. Born from such studies were the design and development of small molecule inhibitors, as shown for ABT-737 in Fig. 3 [50].

Through implementing a number of alternative approaches, either exclusively or in a combined manner, through utilizing natural library screening, peptide therapeutics and structure-based design, a new era in therapeutic targeting has arisen, with most of it focusing on the intrinsic arm of the apoptosis pathway for the treatment of hematological or solid cancers [51-57]. As highlighted in Table 2, this field has diversified from the original $\mathrm{BH} 3$-mimetics (designed to target the antiapoptosis regulators), to the development of Mcl1-based inhibitors (to help overcome Mcl1-derived resistance), and beyond towards the development of Smac-mimetics, which more specifically target the Inhibitors of Apoptosis Proteins (IAPs).
While some agents show off-target effects, such effects are being harnessed advantageously, through devising novel and combined treatment regimens, based on a common vision shared by the scientific communities from the academic and private sectors. Additionally, most classes of therapeutics exhibit a broad protein target range (with non-specific off targets), whilst some have greater specificity (with minimal off-target effects), as seen for Venetoclax and Gossypol (for BH3-mimetics), and numerous agents for Smac-mimetics and Mcl-inhibitors (Table 2).

Consequently, such efforts have given rise to several promising biological agents, reported to induce the death of several cancer cell types in pre-clinical models, and some of which are currently being driven through clinical trials as very promising anti-cancer therapeutics. In the following sub-sections, we aim to review key aspects of the research efforts published over the last 20 years. As an active area of research that has intensely diversified on a number of fruitful tangents, we aim to initially describe the founding members of the $\mathrm{BH} 3$-mimetics group and how the outputs from their evaluation have evolved to give rise to promising therapeutics. We will then turn our attention to how the principles of $\mathrm{BH} 3$-mimetics design and targeting have been applied to spawn a number of promising mimetics derived from the NOXA, PUMA and Smac proteins. Lastly in this subsection, we focus on the most encouraging BH3-mimetic (Venetoclax) and the emerging Mcl-1 inhibitors, which are reportingly showing notable pre-clinical outcomes.

\section{$\mathrm{BCl}-2$ protein targeting mimetics}

Cell fate is determined by the balance of Bcl-2 antiapoptotic protein expression in relation to pro-apoptotic
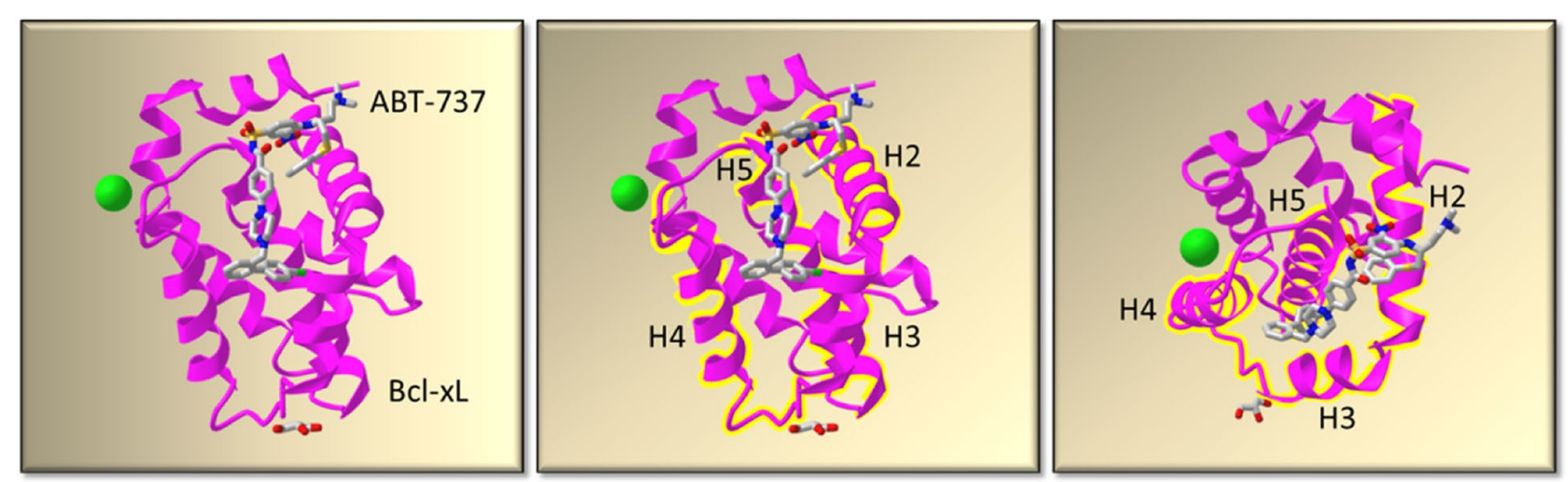

Fig. 3 Co-crystal structure of Bcl-xL and small-molecule inhibitor ABT-737. The interaction of alpha-helices (H) 1-9 from Bcl-xL (pink), in combination with ABT-737 (stick diagram) are highlighted in the presence of a chloride ion (green circle) and glycerol (unlabeled lower stick) in the left panel. $\mathrm{BCl}-\mathrm{xL}$ a-helices 2-5 ( $\mathrm{H} 2-\mathrm{H} 5)$ are highlighted in pink and yellow (middle panel) and in the right panel, are shown when viewed from above 
Table 2 Promising mimetics and inhibitor therapeutic agents for cancer

\begin{tabular}{|c|c|c|c|c|c|c|}
\hline Agent & Type & Origins & Target & Off-Target & Developer & Ref \\
\hline ABT-737 & $\mathrm{BH} 3-\mathrm{M}$ & $\begin{array}{l}\text { Structure-based design, } \\
\text { BAK peptide }\end{array}$ & $\mathrm{BCl}-2, \mathrm{BCl}-\mathrm{xL}$ & - & Abbott Labs. (IL, USA) & [58] \\
\hline Navitoclax & $\mathrm{BH} 3-\mathrm{M}$ & ABT-737 & $\mathrm{BCl}-2, \mathrm{BCl}-\mathrm{xL}, \mathrm{Mcl} 1$ & Mcl1 (weak) & Abbott Labs. (IL, USA) & {$[59]$} \\
\hline $\begin{array}{l}\text { Gossypol } \\
\text { (AT-101) }\end{array}$ & $\mathrm{BH} 3-\mathrm{M}$ & $\begin{array}{l}\text { Structure-based design, } \\
\text { BIM peptide }\end{array}$ & $\mathrm{BCl}-2, \mathrm{BCl}-\mathrm{xL}, \mathrm{Mcl} 1$ & - & University of Michigan (MI, US) & {$[60]$} \\
\hline Obatoclax & $\mathrm{BH} 3-\mathrm{M}$ & In silico docking studies & $\mathrm{BCl}-2, \mathrm{Mcl} 1$ & $\mathrm{BCl}-\mathrm{xL}$ & University of Montreal (CAN) & {$[61]$} \\
\hline Venetoclax & $\mathrm{BH} 3-\mathrm{M}$ & Navitoclax & $\mathrm{BCl}-2$ & $\mathrm{BCl}-\mathrm{xL}$ (weak) & AbbieVie (IL, USA) & {$[62]$} \\
\hline Compound 3 & Smac-M & $\begin{array}{l}\text { Smac (AVPI/AVPF } \\
\text { peptide sequence) }\end{array}$ & $x \mid A P, C I A P 1 / 2$ & NF-KB activation & University of Texas (TX, USA) & $\begin{array}{l}{[63]} \\
{[64]}\end{array}$ \\
\hline APG1387 & Smac-M & Smac (AVPI peptide sequence) & $x|A P, C| A P 1 / 2$ & - & University of Michigan (MI, USA) & {$[65]$} \\
\hline AT-406 & Smac-M & Structure-based design & $x|A P, C| A P 1 / 2$ & - & University of Michigan (MI, USA) & {$[66]$} \\
\hline Compound A & Smac-M & Small molecule screen & $x|A P, C| A P 1 / 2$ & - & University of Texas (TX, USA) & [63] \\
\hline LC161 & Smac-M & Structure-based design & $x|A P, C| A P 1 / 2$ & - & Dana-Farber CI (MA, US) & {$[67]$} \\
\hline SM-164 & Smac-M & Structure-based design & $x \mid A P$ & - & University of Michigan (MI, USA) & {$[68]$} \\
\hline Birinapant & Smac-M & Smac (AVPI peptide sequence) & CIAP1 & xIAP (weak) & Duke University (NC, USA) & [69] \\
\hline A1210477 & Mcl1-I & High throughput screen & Mcl1 & - & $\begin{array}{l}\text { AbbieVie (IL, USA) } \\
\text { Genetech (CA, US) }\end{array}$ & $\begin{array}{l}{[70]} \\
{[71]}\end{array}$ \\
\hline AMG-176 & Mcl1-I & $\begin{array}{l}\text { Structure-based design, } \\
\text { High throughput screen }\end{array}$ & Mcl1 & $\mathrm{BCl}-2, \mathrm{BCl}-\mathrm{xL}$ (minimal) & Amgen (CA, USA) & {$[72]$} \\
\hline AZD-5991 & Mcl1-I & Structure-based design & Mcl1 & - & AstraZeneca (MA, US) & {$[73]$} \\
\hline S63845 & Mcl1-I & In-silico modelling & Mcl1 & - & $\begin{array}{l}\text { Institut de Recherches Servier } \\
\text { Oncology (FRA) }\end{array}$ & {$[74]$} \\
\hline MIM1 & Mcl1-I & Small molecule screen & Mcl1 & - & Dana-Farber CI (MA, USA) & {$[75]$} \\
\hline VU661013 & Mcl1-I & Structure-based design & Mcl1 & BIM-Mcl1 destabilization & Vanderbilt University (TN, USA) & $\begin{array}{l}{[76]} \\
{[77]}\end{array}$ \\
\hline GDC-0941 & Mcl1-I & In-silico modelling & $\mathrm{Pl} 3 \mathrm{Ka} / \delta, \mathrm{Mcl} 1$ & - & Piramed Pharma (UK) & {$[78]$} \\
\hline
\end{tabular}

BH3-mimetics (-M), Smac-mimetics (-M) and Mcl1 inhibitors (-I) are highlighted along with the techniques utilized for their discovery or origins. For each drug, we show its cognate target and off-target proteins or effects, its developer and the publication describing its development (Ref)

BH3 proteins levels, highlighted by the discovery of Bcl-2 being the first anti-apoptotic overexpressed oncogene, as seen in follicular lymphoma [79-81]. Subsequently, 17-18 member proteins have been reported to share at least one of the four Bcl-2 homology domains (BH1-4), in a family of proteins that exhibit anti- or pro- apoptotic expression-dependent effects [82]. As a protein highly expressed in a number of B-cell lymphomas [83, 84], $\mathrm{Bcl}-2$ is expressed in Chronic lymphocytic leukaemia (CLL) [85], Mantle cell lymphoma (MCL) [85-87], Multiple myeloma (t11;14) $(\mathrm{MM})[88]$ or solid tumors [83], and (in a similar manner to Mcl1 expression) is critical for cell survival [89]. Here, high levels of pro-apoptotic protein expression had also been reported [90], thus potentially offering the induction of potent cell death by monotherapeutic BH3-mimetics acting through disrupting the BH3-domain-hydrophobic groove interaction. Mechanistically, this is permitted through the localization of functionally equivalent BAX or BAK proteins [91] to the outer membrane of the mitochondrion through their $\alpha$-helix 9 motifs [92-95], where they can homo-oligomerize and mediate the formation of the MPC, thereby inducing the release of cytochrome $\mathrm{c}$ and other apoptotic inducing or regulatory factors $[96,97]$.

\section{-ABT-737}

The BH3-mimetic ABT-737, was designed using an NMR structure-based approach, which targeted the BH3binding hydrophobic groove of Bcl-2, Bcl-xL (Fig. 3) and Bcl-w (with a Ki of $36 \mathrm{nM}$ ), whilst binding minimally to Mcl1 or A1 [50, 98, 99]. Its effectiveness was observed against cell lines and patient samples derived from lymphoma, leukemia and in senescence of solid tumors in single $[51,100]$ or combined therapy approaches [101103]. However, resistance against the death-inducing effects of ABT-737 was reported in pre-clinical models, mainly due to upregulated Mcl1 protein expression in certain cancer cell types, and the abrogation of which sensitized cells to death, as seen in normal mouse embryonic fibroblast [99, 104], prostate cancer [34] and breast cancer cells [35]. As a potential mechanism for ABT-737 resistance in pre-clinical models, the significance of such a mechanism in clinical studies remains to be explored in greater detail. 
Other aspects of drug resistance were also derived from the stress protein $\mathrm{Bcl}-2$-associated athanogene 3 (BAG3), which could stabilize Mcl1 expression, thus contributing to ABT-737 resistance in breast cancer and prostate cells [105]. Conversely, Mcl1 protein levels were observed to be destabilized when A549 and 95-D cells were treated with Nedaplatin, allowing ABT737 to induce death with greater efficacy [106], thus highlighting the effectiveness of Mcl1 co-inhibition in a viable combined therapeutic strategy, and which was confirmed through ARC-mediated transcriptional down-regulation of Mcl1 expression [107]. Similar ABT-737-enhancing effects have also been reported upon Mcl1 inhibition in retinoblastoma- [108], melanoma- [109], breast-, prostate-, colon- [110] and livercancer cells [111]. While such findings, suggestive of ABT-737 synergizing well with other therapeutics (Table 3 ) are very encouraging (as seen from its therapeutic activity against a diverse repertoire of cell types), poor bioavailability and low aqueous solubility of ABT737 did present themselves as major obstacles against its further use in the clinic.

Table 3 The single and combined synergizing effects of ABT-737 on cell line viability and/or apoptosis

\begin{tabular}{|c|c|c|c|c|c|}
\hline Cancer & Cell Type & Combined & Reduced Viability & Apoptosis & Ref \\
\hline AML & ex-vivo samples & 5-azacytidine & synergized & - & {$[112]$} \\
\hline Breast & MDA-MB-231R & irradiation & synergized & - & [113] \\
\hline Breast & T47D & cisplatin & synergized & synergized & {$[114]$} \\
\hline Breast & MCF-7, ZR-75-1, MDA-MB231 & irradiation & synergized & - & {$[35]$} \\
\hline Breast & MDA-MB-435S & $V X-680$ & synergized & - & [115] \\
\hline Breast (TN) & MDA-MB-231 & docetaxel & synergized & - & {$[116]$} \\
\hline CRC & C26, HCT116, LS174T & oxaliplatin & synergized & - & {$[117]$} \\
\hline CRC & HT-29, HCT116 & celecoxib & synergized & - & {$[118]$} \\
\hline Glioma & LN229, LN18 & bortezomib & synergized & - & [119] \\
\hline HNSCC & UM-22A, UM-22B, 1483 & cisplatin/etopiside & synergized & - & {$[120]$} \\
\hline Lung & A549 and $\mathrm{H} 460$ lines & perifosine & synergized & synergized & {$[121]$} \\
\hline Lung & A549 and 95-D & nedaplatin & synergized & - & {$[106]$} \\
\hline Leukaemia & HL-60, U-937, ML-1, MOLT-4 & -single- & reduced & - & [122] \\
\hline Leukaemia (T-cell) & MOLT-4 & resveratrol & synergized & - & [123] \\
\hline Leukaemia & $\mathrm{HL}-60$ & doxorubicin & synergized & - & [124] \\
\hline Liver & HuH-7, HepG2, BEL-7402, SMMC-7721 & norcantharidin & synergized & - & {$[111]$} \\
\hline Liver & HepG2 & curcumin & synergized & - & [125] \\
\hline Melanoma & A375, WM852C & bortezomib & synergized & synergized & [109] \\
\hline NSCLC & $\begin{array}{l}\text { A549, H460, H1299, H358, H2009, H1703, } \\
\text { H596 }\end{array}$ & cisplatin & - & synergized & [126] \\
\hline Oral & $\mathrm{MC}-3, \mathrm{HSC}-3$ & sorafenib & synergized & - & {$[127]$} \\
\hline Osteosarcoma & $\mathrm{U}-2 \mathrm{OS}$ & cisplatin & synergized & - & {$[128]$} \\
\hline Ovarian/Gastric & SKOV-3, OVCAR-8, SGC-7901 & epothilone B & synergized & - & [129] \\
\hline Ovarian & patient derived organoids & naftopidil & synergized & - & [130] \\
\hline Ovarian & Ovcar-3, Igrov-1 & pitavastatin & synergized & - & {$[131]$} \\
\hline Ovarian & $\begin{array}{l}\text { A2780, cisA2780, IGROV-1, OVCAR, SK-OV- } \\
03 \text {, primary and xenograft }\end{array}$ & carboplatin & synergized & synergized & {$[132,133]$} \\
\hline Prostate & DU 145, LNCaP and PC-3 & ARC & synergized & - & {$[107]$} \\
\hline Renal & PV10, KRC/Y,A498, ACHN & TRAIL & synergized & - & [134] \\
\hline Retinoblastoma & Y79, WERI-Rb & -single- & - & - & [108] \\
\hline Thyroid & FTC236, ML1, SW1736, HTh7 & doxorubicin/gemcitabine & synergized & - & [135] \\
\hline Uterine/Cervical & $\mathrm{SiHa}, \mathrm{CaSki}$ & irradiation & synergized & - & {$[136]$} \\
\hline Breast, Colon, Liver, Pancreatic & $\begin{array}{l}\text { SW480 and LIM1215, Huh-7 and HepG2, } \\
\text { HPAC, MDA-MB-231 }\end{array}$ & ARC & synergized & synergized & {$[137]$} \\
\hline Breast, Colon, Prostate & MDA-MB-231, HT-29, DU145 & methylseleninic acid & synergized & - & [110] \\
\hline
\end{tabular}

The cancer types are highlighted in bold (left column), the evaluation of single therapy alone is highlighted by'-single-', non-synergy is highlighted by'-'and the corresponding studies are referenced in the column on the right (Ref). Abbreviations: TN Triple Negative, CRC Colorectal cancer, HNSCC Head and Neck Squamous Cell Carcinoma, NSCLC Non-small cell lung cancer 


\section{-Navitoclax (ABT-263)}

In striving towards overcoming bioavailability and solubility issues for ABT-737, its redesign gave rise to orally administered Navitoclax (ABT-263) [59], which demonstrated a Ki for Bcl-2 of $<0.010 \mathrm{nM}$ and could bind albumin with greater affinity for potential additional delivery benefits in the clinic. While the latter was seen as an encouraging observation, such an interaction was unveiled to reduce the availability of Navitoclax for during the treatment of CLL patients [138]. Regardless of the delivery method of choice, Navitoclax is currently being evaluated and pursued as single- or combined- anti-cancer therapeutic [48], as seen from its ability to sensitize cervical cancer cell lines [139] for example, or synergize with a number of therapeutics for hematological malignancies [140] (Table 4). Despite consistent side effects for Navitoclax, which included thrombocytopenia, based on Bcl-xL expression-dependency for platelet survival, it was effective at killing Bcl-2-dependent CLL cancers, just as effectively as ABT-737 [138].

Despite such encouraging outcomes, resistance against Navitoclax was also encountered, due to the induction of Mcl1 [159] or Survivin expression [160], and the direct (or indirect) down-regulation of which, were seen as beneficial to Navitoclax efficacy [142, 143]. For example, inhibition of EGF-R mediated Mcl1 induction improved
Navitoclax effects in leukemia K562 cells [161], by destabilizing Mcl1 levels through the upregulation of NOXA expression [148, 154]. Conversely, not all instances of resistance were attributed to Mcl1 expression, as reported for cisplatin-treated non-small cell lung cancer cells (NSCLC), which induced cell death independently of Mcl1 expression levels [151].

\section{-Gossypol}

Other broad-range BH3-mimetics include Gossypol and its derivatives. Derived from cotton seed extracts and identified using NMR binding assays and Fluorescence Polarization displacement assays, racemic Gossypol directly interacted with Bcl-xL and could also counteract the anti-apoptotic effects of Bcl-2, with an $\mathrm{IC}_{50}$ of $13.2 \mu \mathrm{M}$ in MCF-7 cells, as a pan-Bcl-2 inhibitor [52]. Gossypol also inhibits growth and induces apoptosis in several other cell types, such as H1975, H441 and A549 lung cells as a mono-therapeutic in a dose-dependent manner, while also reducing H1975 xenograft growth in mice [162]. It can inhibit EGFR-L858R/T790M signaling, proliferation and migration of NSCLC cells [163], induce death of prostate cancer DU-145 and PC-3 cells [164, 165] and ovarian SKOV3 cancer cells [166]. Fortuitously, racemic Gossypol can also behave as a NOXAlike BH3-mimetic, by selectively promoting apoptosis

Table 4 The single- and combined- synergizing, or resistance-inducing effects of Navitoclax on cellular apoptosis

\begin{tabular}{lllr}
\hline Cancer & Cell Type & Combined & Apoptosis \\
\hline AML & Primary cells & dasatinib & - \\
AML/ALL & Jurkat, Molt-4 & wogonin & synergized \\
Cervical & SiHa, CaSki & A-1210477 & [142] \\
CRC & HCT116, DLD1, SW48, HT29, HCT-8 & apigenin & synergized \\
CRC, Liver & Huh7, HepG2, BEL7402, HCT116, DLD1, AGS & sorafenib & synergized \\
CRC/Melanoma & Colo-205 & AZD6244 resistance & synergized \\
Esophageal & SKGT-4, KATO-TN, YES-6 & fluorouracil & [144] \\
Esophageal & EC109, HKESC-2, CaES-17 & -single- & [145] \\
HNSCC & HN12 & fenretinide & synergized \\
Liver & Huh7 & TRAlL resistance & - \\
Lung & H1650 and H1975 & src-inhibitors & synergized \\
Non-small cell lung & LC2, PC10 & cisplatin & [147] \\
Small cell lung & H209 & vorinostat & synergized \\
Lymphoma & DoHH-2 and SuDHL-4 & rapamycin & [149] \\
Neuroblastoma & SH-SY5Y and CHLA-119 & norcantharidin & synergized \\
Prostate & LNCaP and PC3 & paclitaxel & [151] \\
Prostate & PC3, C4-2B, C4-2, DU145 & MLN2238 & [152] \\
Ovarian & Numerous & paclitaxel/gemcitabine & [153] \\
Liver, Prostate, Cervical, \\
CRC, NSCLC & Hep3B, PC3, HCT-116, SW480, and SW620, H1299, & metformin & synergized \\
\hline
\end{tabular}

The cancer types are highlighted in bold (left column), the evaluation of single therapy alone is highlighted by -single-, non-synergy is highlighted by'-'and the corresponding studies are referenced in the column on the right (Ref). Abbreviations: AML Acute Myelogenous Leukemia, ALL Acute Lymphoblastic Lymphoma, CRC Colorectal cancer, HNSCC Head and Neck Squamous Cell Carcinoma, NSCLC Non-small cell lung cancer 
of cancer cells from the bladder [167], breast [168, 169] and prostate [170], when administered as a mono-therapeutic. Mechanistically, Gossypol can reduce cellular viability upon p53 activation, as seen in LAPC4, PC-3, and DU-145 prostate cancer (PC) cells [171], through ER stress and autophagy in hepatocellular carcinoma (HCC) cells [172], and oxidative stress, as seen in ovarian and MM cells $[166,173]$. As a combined therapeutic, it has been reported to induce autophagy and apoptosis in a cell type-dependent manner [174] or exclusively autophagy in melanoma cells [175]. Alternatively, the R()-Gossypol enantiomer AT-101, has also been encouragingly reported to reduce invasiveness of rat MLL PC cells [176] and induce mitophagy in U87MG and U343 glioma cells [177]. Mechanistically, Gossypol and AT-101 may contribute to cell death by binding and inhibiting Mcl1, resulting in the sensitization of several cell lines to other therapeutics or through it stabilizing NOXA expression, as in gastric, breast and nasopharyngeal cell lines [178, 179]. Collectively, racemic Gossypol or its enantiomer are showing good potential as anti-cancer agents which induce cell death through a variety of mechanisms, and in a variety of cell line-based models. They can be effective as a single- or combined- therapeutics (Table 5), but the activity of which may be limited through the levels of toxicity that arise from administering increasing doses [183].

Based on toxicity effects, alternative Gossypol derivatives and analogues have been developed, based on the structural binding properties of the BIM protein BH3domain with the Bcl-2 protein, namely TW-37 (Compound 5), and which can also bind Bcl-xL and Mcl1 with respective Ki's of 1110 and $260 \mathrm{nM}$ [60]. As emerging alternatives to Gossypol, their further evaluation in model systems and potential use as single or combined therapeutics are awaited with great eagerness.

\section{-Obatoclax}

Another promising BH3-mimetic, specific for all $\mathrm{Bcl}-2$ proteins includes the rationally-designed and prodiginine-related Obatoclax, which binds the mitochondrially-associated Bcl-2 protein and all pro-survival Bcl-2 proteins with a Ki of $220 \mathrm{nM}[61,190]$, outlining its suitability for the treatment of hematological malignancies and solid tumors [191, 192]. Good evidence to support this has been derived from xenograft models, where its successful use as a single agent against thyroid cancer, small cell lung cancer and colorectal cancer development has been reported, and efficacy of which can be enhanced when used as a combined therapeutic in limited instances with cisplatin, MEK inhibition, doxorubicin [193, 194], bortezomib, carfilzomib or AZD2281, as highlighted in Table 6.

Moreover, Obatoclax has completed phase I trials for several cancers with encouraging efficacy, but with notable side effects [191, 192].

\section{NOXA-mimetics}

As to be expected NOXA expression plays a relatively restricted role in determining cell fate and tumor progression in the presence and absence of therapeutic treatments against LC [210-213], leukemias [214, 215], rhabdomyosarcoma [216, 217], PC [218], OC [219], colorectal cancer (CRC) [220, 221], melanoma [222] and

Table 5 The combined synergizing effects of Gossypol and its derivative (AT-101) against certain cancers and cell types

\begin{tabular}{|c|c|c|c|c|c|}
\hline Mimetic & Cancer & Cell Type & Combined & Apoptosis & Ref \\
\hline Gossypol & Glioblastoma & Diff13-20, TS13-20 & temozolomide resistance & - & [180] \\
\hline Gossypol & CML & K562 & imatinib & - & [181] \\
\hline Gossypol & Colon & HT-29 cells, HCT116, RKO & fluorouracil & - & [182] \\
\hline Gossypol & $\begin{array}{l}\text { Nasopharyngeal, Breast, } \\
\text { Gastric }\end{array}$ & MCF-7, YC116, CNE2 & gemcitabine & - & [183] \\
\hline Gossypol & Ovarian & OVCAR-3 and MDAH-2774 & zoledronic acid & - & [184] \\
\hline Gossypol & Thoracic & $\mathrm{H} 460, \mathrm{TE} 2, \mathrm{H} 211$ & TRAIL & - & [185] \\
\hline AT-101 & Bladder & UM-UC2, UM-UC9 & gemcitabine, carboplatin & synergized & [167] \\
\hline AT-101 & Breast & SKBR-3, MDA-MB-453 & trastuzumab & - & [186] \\
\hline AT-101 & Pancreatic & $\mathrm{B} \times \mathrm{PC}-3$ & genistein & - & [187] \\
\hline AT-101 & Prostate & PC-3 and xenograft & radiation & - & [188] \\
\hline AT-101 & Prostate & PC-3 xenograft & docetaxel & synergized & [170] \\
\hline AT-101 & Prostate & DU145, PC-3 & sorafenib & - & [174] \\
\hline AT-101 & Prostate & VCaP & bicalutamide & - & [189] \\
\hline
\end{tabular}

The therapeutic type is highlighted in bold (left column), non-synergy is highlighted by'-'and the corresponding studies are referenced in the right column (Ref). Abbreviations: CML Chronic Myelogenous Leukemia 
Table 6 The combined synergizing effects of Obatoclax on cellular apoptosis

\begin{tabular}{|c|c|c|c|c|}
\hline Cancer & Cell Type & Combined & Apoptosis & Ref \\
\hline AML & U937, HL-60, MV4-11 & sorafenib & - & [195] \\
\hline Bladder & HT1197 & paclitaxel & - & [196] \\
\hline Bladder & T24, TCCSuP, 5637 & cisplatin & - & {$[197]$} \\
\hline Cholangiocarcinoma & $\mathrm{KMCH}, \mathrm{KMBC}, \mathrm{TFK}$ & TRAIL & - & [198] \\
\hline Colon & HCT116, HCT-8, & fluorouracil & - & [199] \\
\hline Esophageal & CaES-17 & MG132 & - & {$[200]$} \\
\hline Glioblastoma & Patient samples & SAHA, LBH589 & - & {$[201]$} \\
\hline Small cell lung & H82, H526, DMS79, H196, H1963, H69 & bortezomib and carfilzomib & synergized & [202] \\
\hline Non-small cell Lung & LoVo, RKO, HCT116 & oxaliplatin resistance & - & [203] \\
\hline Neuroblastoma & SK-N-DZ, IGR-NB8 & $\begin{array}{l}\text { hydroxychloroquine/cisplatin/ } \\
\text { doxorubicin }\end{array}$ & - & {$[204]$} \\
\hline Pancreas & $\mathrm{BxPC}-3$ & gemcitabine & - & {$[205]$} \\
\hline Pancreas & PANC-1 and BxPC-3 & TRAIL & - & {$[206]$} \\
\hline Pancreas & BXPC-3, HPAC & chloroquine & - & {$[207]$} \\
\hline Pancreas & $\begin{array}{l}\text { BXPC-3, HPAC, MIAPaCa-2, PANC-1, AsPC-1, } \\
\text { CFPAC-1 }\end{array}$ & AZD2281 & synergized & [208] \\
\hline Thyroid & KTC-1, BCPAP & LY3009120/vemurafenib resistance & - & {$[209]$} \\
\hline
\end{tabular}

The cancer types are highlighted in bold (left column), non-synergy is highlighted by'-'and the corresponding studies are referenced in the column on the right (Ref). Abbreviations: AML Acute Myelogenous Leukemia

MM [223]. As a protein up-regulated in CLL, NOXA can interact with Mcl1 and neutralize its anti-apoptotic activity [224], thus offering good justification for the development of NOXA-like BH3-mimetics, and particularly for CLL therapy [225]. Here, Mcl1-derived inhibitors had been reported to be sufficient to induce apoptosis through their specific targeting of NOXA. While encouraging, such an approach may come with limitations, seeing as anti-apoptotic proteins (such as NOXA) are embedded in the mitochondrial membrane and more susceptible to changes in their conformation, and which may consequently respond differently to the affinity of mimetics in comparison to BH3-mimetics which are otherwise directed at soluble targets [14].

\section{PUMA-mimetics}

The BH3-only protein PUMA, is frequently down-regulated in a number of tumors [26], and which may contribute to chemoresistance and tumor progression in conjunction with other protein factors, based on the phenotype of PUMA knockout-mice lacking spontaneous oncogenesis [226]. Nevertheless, PUMA-derived helices in the form of SAHBs [227], which have the capacity to bind BAX or Bcl-xL/Mcl1 as dual anti-apoptosis inhibitors that induce BAX activation, have shown some encouraging outputs in overcoming chemoresistance in neuroblastoma cells. As in the instance of BH3-mimetics, the starting point here has been the design of peptide inhibitors, which can potentially take up a helical conformation upon binding the hydrophobic groove of BAX,
Bcl-xL or Mcl1 [228, 229], or through them being generated as stapled peptides [228].

\section{SMAC-mimetics}

The human Inhibitor of Apoptosis (IAP) family of proteins are composed of eight members, each of which encode a Baculoviral IAP Repeat domain (BIR) and several of which are over-expressed in hematological malignancies and solid tumors [230-232]. While each member can regulate cell survival in response to a number of signaling cues, cIAPs and XIAPs have direct anti-apoptotic roles [233, 234] and offer chemoresistance when over-expressed in cancer cells [230]. Mechanistically, they can be targeted through homodimers of Smac binding the BIR domain and destabilizing the IAP protein through IAP auto-ubiquitination and degradation [235-238]. Consequently, cells can be sensitized to the apoptosis-inducing effects of TRAIL with PI3K or MAPK inhibition $[239,240]$ and etoposide or paclitaxel [241] in combined therapeutic approaches. As monotherapeutics, Smac-mimetics can act through preventing inhibitory IAP binding to caspases -3, -7, -9 [242-245] and thus potentiating the effects of any death-inducing signals [230]. Therefore the loss of Smac expression can negatively impact the full execution of apoptosis, as seen with some cancer patients encoding high levels of Smac expression, and which can be correlated with a better prognosis [230]. Consequently, targeting the Smac-IAP interaction has been explored as a therapeutic strategy through the use of SMIs, peptides [230], LAso 
Smac-mimetics or Smac anti-sense oligonucleotides, and all of which showed varying degrees of success. For example, Smac-mimetics induced the degradation of cIAPs $-1,-2$ and -3 via the proteasome, leading to NIK activation, NF- $\mathrm{kB}$ activation, and up regulation of TNF- $\alpha$ expression and subsequently cell death in an autocrineor paracrine- manner, in treated fibrosarcoma, colorectal and melanoma cell lines [235, 238]. Generally speaking, Smac-mimetics can be as little as 4 aa long and which can target BIR repeats -3 and -4 of the three cIAPs [246]. While they have shown good effects against specific solid tumors and leukemias as mono-therapeutics [247], they can also sensitize cells to death in combined therapeutic regimens, as seen with temozolomide [248], cytarabine [249], prednisolone [250] and even the pro-inflammatory cytokine TNF- $\alpha[251,252]$, in a variety of cell types (Table 7).
Smac-mimetics or IAP inhibitors have also shown effectiveness with death receptor agonists in a variety of cell types, as seen against TRAIL in -CLL [282], -ALL [283] and -cholangiocarcinoma cell types [284], or with radiation-induced death of glioblastoma cells [285]. Similarly, signal transduction inhibitors have been reported to improve efficacy of treatments when administered in combination with Smac-mimetics, as seen with 5-Aza against AML cells [286, 287], tyrosine kinase inhibitors against leukemia cells [67, 288], CD95 agonist antibodies against leukemia cells [289], or Smac-mimetics and TNF- $\alpha$ against alveolar epithelial cells [290]. Lastly, some Smac-mimetics exhibit synergistic effects with Birinapant-induced death of liver cancer cells [291], triple-negative BC cells (TNBC) [292], ovarian cancer (OC) cells [260] and primary AML cells in response to BV6 [262].

Table 7 The combined synergizing effects of Smac-mimetic (or IAP inhibitor) agents against selected cancers and cell types

\begin{tabular}{|c|c|c|c|c|}
\hline Agents & Cancer & Cell Type & Combined & Ref \\
\hline APG-1387 & Liver & HepG2 and HCCLM3 & TNF-a, TRAIL & [253] \\
\hline APG-1387 & Ovarian & SKOV3 & TNF-a & [254] \\
\hline AT-406 & Osteosarcoma & AT-406, Xenograft & doxorubicin & {$[255]$} \\
\hline AZ58 & Bladder & UMUC-6, UMUC-12, and UMUC-18 & gemcitabine, cisplatin & {$[256]$} \\
\hline Birinapant & AML & MLL-ENL AML & emricasan & {$[257]$} \\
\hline Birinapant & Breast & SUM190, SUM149 & TRAIL & {$[69]$} \\
\hline Birinapant & Head and Neck & UM-SCC-46 and -11 B xenograft & radiation & {$[258]$} \\
\hline Birinapant & Non-small cell Lung & LKB1- and KRAS-mutated & ralimetinib & [259] \\
\hline Birinapant & Ovarian & CAOV3, OVCAR4, SKOV3, OVCAR8, OV90, 1 A9 & docetaxel & {$[260]$} \\
\hline Birinapant & Ovarian & OCAR3, OVCAR8 & carboplatin/ paclitaxel & [261] \\
\hline BV6 & AML & $51 \%$ primary AML cells & cytarabine & [262] \\
\hline BV6 & Glioblastoma & - & temozolomide & {$[263]$} \\
\hline BV6 & CRC & SW480, HT-29, HCT-15 & radiation & [264] \\
\hline BV6 & Glioblastoma & $\mathrm{A} 172, \mathrm{~T} 98 \mathrm{G}$ & temozolomide & {$[265]$} \\
\hline BV6 & Multiple & HT1080, HeLa, Jurkat, L363, MMI, OPM2, RPMI, HT29 & TNF-a, TRAIL & {$[266]$} \\
\hline BV6 & Renal & CaKi1, KTCTL26, 7860, KTCTL30, KTCTL2 & interferon- $a$ & {$[267]$} \\
\hline JP-1201 & CRC & HT-29 & radiation & [268] \\
\hline$J P-1201$ & Pancreas & Xenograft MIA PaCa-2 & gemcitabine & [269] \\
\hline LCL161 & B-Cell Lymphoma & Xenograft Raji/4RH & rituximab, gemcitabine, vinorelbine & {$[270]$} \\
\hline LCL161 & Breast & MCF7-TamC3 & tamoxifen & {$[271]$} \\
\hline LCL 161 & HNSCC & human cell culture, xenograft & radiation & {$[272]$} \\
\hline LCL161 & HNSCC & PCl-1, PCl-9, PCl-13, PCl-52, PCl-68 & FAS-L & [273] \\
\hline SM-164 & Breast & (SK-BR3) and (MDA-MB-468 & radiation & {$[274]$} \\
\hline SM-164 & Breast, Prostate, Colon & Cell lines & TRAIL & [275] \\
\hline SM-164 & Pancreatic & Panc-1, AsPC-1, BxPC-3 & gemcitabine & {$[276]$} \\
\hline compound A & Bladder & UC-9. UC-14, RT4 v1, RT4 v6 & TRAIL & {$[277]$} \\
\hline compound 3 & Pancreas/CRC & Panc- 1 and HCT116 & doxorubicin & [278] \\
\hline Debio 1143 & Lung & LLC-OVA & radiotherapy & [279] \\
\hline SH122 & Prostate & DU145, CL1 & TRAIL & [280] \\
\hline SW IV-134 & Pancreatic & PANC-1, CFPAC-1, BxPC-3, AsPC-1, MIA PaCa-2 & gemcitabine & {$[281]$} \\
\hline
\end{tabular}

The therapeutics types (Agents) are highlighted in bold (left column) and the corresponding studies are referenced in the column on the right (Ref). Abbreviations: AML Acute Myelogenous Lymphoma, CRC Colorectal cancer, HNSCC Head and Neck Squamous Cell Carcinoma 


\section{-Venetoclax (ABT-199)}

Venetoclax was developed through rational design approaches as a high-affinity antagonist for Bcl-2 (with a $\mathrm{Ki}<0.010 \mathrm{nM}$ ) and a 4000 fold lower affinity binding for $\mathrm{Bcl}-\mathrm{xL}$, to help overcome thrombocytopenia side effects derived from off-target $\mathrm{Bcl}-\mathrm{xL}$ inhibition, and a common feature associated with ABT-737 and Navitoclax treatments [62]. While Venetoclax could induce therapeutic resistance by up-regulating Bcl-xL and Mcl1 expression in some instances [293], it has shown encouraging results as a single agent for treating acute lymphocytic leukemia (ALL) [294], head and neck squamous cell carcinoma (HNSCC) [295] and neuroblastoma [296, 297] in preclinical models. Through structure-based design, other ABT-737-derived SMIs targeting Bcl-2 and Bcl-xL, have also arisen in the form of BM-957 and BM-1197, which showed improved solubility, pharmokinetic properties and tumor regression capabilities [298, 299], as single therapeutics against AML [300]. More specifically, such agents spared platelets [62] and to avoid therapeutic resistance, Gemcitabine was reported to effectively decrease Mcl1 expression, while enhanced Bcl-2 expression (in pancreatic cancer cells), could be efficiently targeted by Venetoclax through it beneficially enhancing expression of BIM [301]. Similarly, Venetoclax has shown encouraging results for synergizing with a growing array of therapeutics in pre-clinical models for several cancer cell types, as a well-tolerated combined therapeutic (Table 8).

\section{Mcl1-inhibitors}

As the first homologue of $\mathrm{Bcl}-2$ found to be overexpressed in a number of hematological malignancies such as MM [316], and which conferred anti-apoptotic effects under normal conditions [317-320], Mcl1 expression was also reported to contribute to chemoresistance, thus highlighting its suitability to be targeted in combined therapeutic approaches. Normally, Mcl1 is localized to the MOM [321], ER, nucleus [322, 323], and mitochondrial matrix [321] in conjunction with its spliced variants Mcl-1S [324-326] and Mcl-1ES [327]. As a protein that is essential for survival of a number of normal cell types [328] it has been reported to be over-expressed in a number of other cancers, such as B- and T- non-Hodgkin's lymphoma [329], and solid tumors, such as hepatocellular carcinoma (HCC) [330], esophageal squamous cell carcinoma (SCC) [331] and breast cancer (BC) [332].

Based on these properties of Mcl1 expression, Mcl1inhibitors have been eagerly pursued, giving rise to the discovery of Prodigiosin for example, which is a natural compound that targets the hydrophobic groove of Mcl1 with good specificity [333]. Based on the normal role of Mcl1 for hematopoietic stem cell survival [334] and oxidative phosphorylation [321], the development of most

Table 8 The combined synergizing effects of Venetoclax on cellular apoptosis

\begin{tabular}{|c|c|c|c|c|}
\hline Cancer & Cell Type & Combined & Apoptosis & Ref \\
\hline ALL & LOUCY cell line & doxorubicin, I-asparaginase, and dexamethasone & - & [302] \\
\hline AML & Primary cells and U937 & daunorubicin or cytarabine & - & [303] \\
\hline AML & KOPT-K1 & S63845 & synergized & [304] \\
\hline AML & MV4-11 and MOLM-13, KG-1a, U937, and THP-1 & triptolide & synergized & [305] \\
\hline AML & Jurkat and Molt4 & gemcitabine & synergized & [306] \\
\hline AML & Molm14 and OCI-AML3 & VS-4718 & - & [307] \\
\hline AML/MDS/CMML & Ex-vivo samples & 5-azacytidine & - & [112] \\
\hline Breast & 23T Xenografts and MCF7 & tamoxifen, AZD8055 & - & [308] \\
\hline CML & KCL22 & imatinib & sensitized & [309] \\
\hline CRC & Xenograft and RKO cell line & LZT-106 & synergized & [310] \\
\hline Diffuse $B C L$ and $F L$ & Cell lines and TMD8 xenograft model & ibrutinib & synergized & [311] \\
\hline Leukemia, Lymphoma & $\begin{array}{l}\text { SU-DHL-4, OCI-Ly1 199R, SC-1199R and BCl and FL } \\
\text { primary samples }\end{array}$ & A-1592668 and analogue A-1467729 & synergized & [312] \\
\hline Nasopharyngeal & CNE-2, 5-8F & S63845 & synergized & [293] \\
\hline MM & OPM2, H929 & THZ1 & synergized & [313] \\
\hline MM & U266, KMS11, OPM2, RPMI8226 and KMS28-PE & flavopiridol & synergized & [314] \\
\hline Pancreatic & MIA Paca-2 xenograft & gemcitabine & - & {$[301]$} \\
\hline Soft Tissue Sarcoma & $\begin{array}{l}\text { Rhabdomyosarcoma, SW982 (synovial sarcoma) cells } \\
\text { or primary cells }\end{array}$ & bortezomib & synergized & [315] \\
\hline
\end{tabular}

The cancer types are highlighted in bold (left column), non-synergy is highlighted by'-'and the corresponding studies are referenced in the column on the right (Ref). Abbreviations: AML Acute Myelogenous Leukemia, ALL Acute Lymphoblastic Lymphoma, MDS Myelodysplastic syndrome, CMML Chronic myelomonocytic leukemia, $B C L$ B-cell lymphoma, FL Follicular Lymphoma, MM Multiple myeloma 
Mcl1 antagonists has been seen to offer potential limitations when used as a mono-therapeutic.

Alternative Mcl1-specific mimetics or inhibitors are also showing their usefulness as mono- or combinedtherapeutics, as seen with S63845-mediated apoptosis of MM and NSCLC, gastric cancer (GC), PC, [74] and T-cell acute lymphoblastic leukaemia (T-ALL) cells [304] or ABT-199 and S63845 co-treatments in cervical cancer cells [335]. Other, promising Mcl1-specific candidates as combined therapeutics include, A-1210477 (Ki, $0.45 \mathrm{nM})$ [70], AZD5991 (Ki, 0.13 nM) [73] and AMG-176 (Ki, $0.13 \mathrm{nM})$ [72], AM8621 (Ki, $0.06 \mathrm{nM})$
[72], S64315 (Ki, $0.048 \mathrm{nM}$ ) [336] and VU661013 (Ki, 97 pM) [76], as outlined in Table 9.

From this group, AZD5991 showed promising effects [363, 364], either as a monotherapy or as a combined agent [73], to treat a number of hematologic and solid tumor cell lines. It also showed combined effectiveness against biomarker-specific and Venetoclax-resistant AML cells, highlighting its usefulness for cell line- or biomarker- specific cancers [365]. Of similar interest is AZD0466, which can also be administered using nanoparticle technology as novel delivery method [366].

Table 9 The combined synergizing effects of Mcl1-inhibitors against selected cancer and cell types

\begin{tabular}{|c|c|c|c|c|}
\hline Agents & Cancer & Cell Type & Combined & Ref \\
\hline A1210477 & AML & THP-1 U937 & venetoclax & {$[337]$} \\
\hline A1210477 & Breast & MDA-MB-231 cells & TRAIL & [338] \\
\hline A1210477 & Cervical & SiHa and CaSki & navitoclax & [139] \\
\hline A1210477 & CML & $\mathrm{K} 562, \mathrm{~K} 562 / \mathrm{R}$ & EE-84 & [339] \\
\hline A1210477 & CRC & RKO, HT29, A375 & cobimetinib & [340] \\
\hline A1210477 & DLBCL & U-2946 & navitoclax & [341] \\
\hline A1210477 & PC, GC, NSCLC, MM & BXPC-3, EJ-1, H23, and OPM-2 & navitoclax & {$[70]$} \\
\hline A1210477 & HNSCC & PCI15B, Detroit 562, MDA686LN, and HN30 & navitoclax & [342] \\
\hline A1210477 & $\mathrm{nHL}$ & SU-DHL-4, WSU-NHL, WSU-DLCL2, KARPAS-422 & venetoclax & [343] \\
\hline AMG-176 & CLL & Patient samples (5) & venetoclax & [344] \\
\hline AZD-5991 & AML & OCl-AML3 and MCL-1-OE Molm13 and MV4-11 & venetoclax & [345] \\
\hline AZD5991 & $\mathrm{MM}$ & $\mathrm{NCl}-\mathrm{H} 929$ & bortezomib, venetoclax & {$[73]$} \\
\hline GDC-0941 & Breast & MDA-MB-231, SKBR3 & ABT-737 & [346] \\
\hline Mim1 & Glioblastoma & U87mg & temozolomide & [347] \\
\hline Mim1 & Melanoma & C32 melanoma cells & dacarbazine & [348] \\
\hline Mim1 & $\mathrm{MM}$ & Colo829 & dacarbazine & [349] \\
\hline S63845 & AML & OCI-AML3, MOLM-13, OCI-AML2 & trametinib/HDM201 & [350] \\
\hline S63845 & $\mathrm{AML}$ & Primary samples & venetoclax & [351] \\
\hline S63845 & AML & MOML-13, SKM-1, & trametinib & [352] \\
\hline S63845 & AML & Cell lines and primary cells & venetoclax & [353] \\
\hline S63845 & Breast & SK-BR-3 & docetaxel, trastuzumab, lapatinib & [354] \\
\hline S63845 & CRC & HCT116 & regorafenib & [355] \\
\hline S63845 & Mantle cell lymphoma & Patient-derived xenografts & venetoclax & [356] \\
\hline S63845 & Melanoma & Patient samples & navitoclax & [357] \\
\hline S63845 & Melanoma & MeWo & TRAIL resistance & [358] \\
\hline S63845 & Myeloma & U266 xenograft & venetoclax & [359] \\
\hline S63845 & MM & MOL-P8, OPM-2, NCl-H929 & venetoclax, bortezomib & {$[360]$} \\
\hline S63845 & MM & RPMI-8226 xenograft & venetoclax & {$[361]$} \\
\hline S63845 & Nasopharyngeal carcinoma & CNE-2, 5-8F & venetoclax & [293] \\
\hline S63845 & T-ALL & Zebrafish T-ALL cells & venetoclax & {$[304]$} \\
\hline VU661013 & AML & MV-4-11, AML-001/2, patient xenografts & venetoclax & {$[76]$} \\
\hline VU661013 & Breast & HCC1428, MCF7, T47D & navitoclax & {$[362]$} \\
\hline
\end{tabular}

The therapeutic types (Agents) are highlighted in bold (left column) and their corresponding studies referenced in the column on the right (Ref). Abbreviations: CML Chronic Myelogenous Leukemia, CRC Colorectal cancer, DLBCL Diffuse large B-Cell Lymphoma, PC Prostate Cancer, GC Gastric Cancer, NSCLC Non-small cell lung cancer, MM Multiple myeloma, HNSCC Head and Neck Squamous Cell Carcinoma, $n H L$ Non-Hodgkin's Lymphoma, CLL Chronic lymphocytic leukemia, $A M L$ Acute Myelogenous Lymphoma, T-ALL T-cell acute lymphoblastic leukemia 
Alternatively, S63845 [74] is also showing good promise, although its optimal use is not fully

defined [367], but nevertheless, can be used as a monotherapy against T-ALL [304] using MOLT-3, RPMI-8402 or neuroblastoma patient cells [297] and can be delivered using nanoparticles to improve remission and therapeutic indices [368].

As drug resistance can be mediated by Mcl1 up-regulation in a number of cancer types [369], which can be sensitized to death upon Mcl1 down-regulation (as in the instance of some ABT-737 co-treatments) [99], Mcl1 inhibitors are therefore viewed as having better potential for combined chemotherapeutic treatments. Alternative approaches that induce Mcl1 proteasomal degradation (by GDC-094 treatments, for example), have also been effective in overcoming resistance, thus allowing ABT737 to have greater effects against BC cells [346] and lung cancer (LC) cells [106]. Similar effects have also been reported for Mcl1 inhibition and TRAIL co-stimulation of BC cells [338]. Conversely, stabilization of Mcl1 protein by BAG3 and survival of $\mathrm{BC}$ and $\mathrm{PC}$ cells under ABT-737 stimulatory conditions has also been reported [105], highlighting a central but indirect and positive regulatory mechanism for the Mcl1 protein as a therapeutic resistance factor. In a similar manner, the interaction of Mcl1 with other protein regulators cannot go ignored and may help in overcoming ABT-737 resistance, as seen from the NOXA protein interacting with Mcl1 $[211,370]$. Here, enhancing NOXA levels, suppressed the anti-apoptotic actions of Mcl1 and override resistance to ABT-737, with Vorinostat [152], Vinblastine [371], Bortezomib [109], Dinaciclib [372] co-treatments in SCLC, CLL and melanoma cells.

Transcriptional repression of Mcl1 expression has also been reported as an effective approach to overcoming drug resistance as reported in the instance of HCC sensitization to ABT-737 and Norcantharidin cotreatments [111]. Alternatively, inhibition of Mcl1 can also be induced through mitochondrial stress or under Obatoclax stimulatory conditions, which can initiate autophagy-dependent necroptosis as an alternative to cell death by apoptosis [373].

As mentioned, of emerging interest are studies being performed in the presence of specific genetic biomarkers [351]. For example, AML primary samples with an IDH2-140 mutation were more sensitive to Venetoclax as a single agent, whereas samples with a FLT3-ITD mutation were more resistant, which is an effect that could be reversed with $\mathrm{S} 63845$ co-treatments [351]. Similarly, AMG-176 [72] has also been shown to be effective as a monotherapy directed against Mcl1 in CLL lymphocyte patient samples [344] and in combination with Venetoclax [344]. Lastly, stapled peptides can also activate and promote BAX/BAK/BIM proteins [374], which also validates findings from previously published structural studies [375, 376]. For example $\operatorname{Bim}_{\mathrm{S}} 2 \mathrm{~A}$, a hydrocarbon stapled BIM BH3-peptide can override Mcl1 mediated drug resistance in cell lines [377] only when Bcl-xL is absent or neutralized [378]. Additionally, Mcl1-specific MIM1 was identified in a stapled peptide-based screen [75], which showed good efficacy as a monotherapy against colo-829 melanoma cells, and which synergized the death inducing effects of ABT-737 or Decarbazine $[349,379]$. When taken with reports that the Mcl1 hydrophobic groove is more rigid than the hydrophobic groove of Bcl-xL [14], targeting Mcl1 may be permitted with greater specificity and affinity and which may even offer some very promising outcomes with minimal non-specific side effects towards Bcl-xL. Consequently, induced Mcl1 expression can potently enhance drug resistance in cancer cells treated with BH3-mimetics and Mcl1 inhibitors are showing their true potential in over-coming this when utilized in combined- therapeutic treatments, in pre-clinical studies.

To summarize, a growing number of BH3-mimetics have been designed and show good efficacy for inducing cell death at $\mathrm{nM}$ quantities. Here, compounds such as ABT-737, Obatoclax and Gossypol, have even been reported to show broader specificity by displacing antiapoptotic proteins Bcl-2, Bcl-xL and Mcl1, thus enhancing their effectiveness at inducing or sensitizing cells to apoptosis in a number of hematological cancers and solid tumors [51, 61, 100, 190, 380-382]. However, such studies have also indirectly unveiled the importance of Bcl-xL in platelet homeostasis, thus inspiring alternative targeting strategies, and which arrived at the further development of Navitoclax- and Venetoclax- derivatives, which eliminate $\mathrm{Bcl}-\mathrm{xL}$ protein levels through protein degradation [383, 384]. Limitations to one side, such stoic examples offer great promise as therapeutics, the development of which have also encouraged avenues of research to overcome important considerations, such as off-target effects, bioavailability, and solubility.

In view of the surge in efforts at developing promising mimetics at the preclinical level, one central question that has been raised originates from how well basic-research efforts have developed in the direction of translational medicine. Although the Venetoclax and Mcl1-inhibitor paradigms lay strong foundations for other mimetics to developmentally follow suit by (at the pre-clinical and clinical level), a significant number of the resulting therapeutics still remain to be evaluated in the clinic. Therefore, in the following sections we highlight what progress has been made over the last $5-10$ years in bringing the most promising aspects of specific therapeutic strategies towards fruition, as seen from published clinical trials. 


\section{BH3-mimetics and Bcl-2 protein inhibition: a clinical perspective $-A B T-737$}

Although ABT-737 showed promising therapeutic properties in pre-clinical cell line-, primary cell- and animalmodels against cancers over-expressing Bcl-2 or Bcl-xL [51], to date only two clinical trials for ABT-737 have been publicized (www.clinicaltrials.gov). These addressed the effects of platinum combined with ABT-737 against ovarian cancer (NCT01440504) and the use of ABT-737 ex-vivo on apoptosis of platelets in idiopathic thrombocytopenic purpura patients co-treated with Eltrombopag and Romiplostim (NCT00902018, [385]). While the findings from the former study remain to be published, in the latter study (NCT00902018), $8 \mathrm{~h}$ and $3 \mathrm{~h}$ treatments of ABT-737 sensitized patient platelets to apoptosis, and Eltrombopag pre-treatment for 1 week gave rise to therapeutic resistance towards ABT-737, possibly due to a recorded increase in the ratio of $\mathrm{Bcl}-\mathrm{xL}$ :BAX proteins or enhanced Akt signaling and Mcl1 expression in patient samples. As the prototypical BH3-mimetic [51], ABT-737 did encouragingly enter clinical trial phases I/II, but poor solubility and oral bioavailability $[59,386]$ did offer limitations in its dose adjustments during combined or single treatment approaches [387].

\section{-Navitoclax (ABT-263)}

As the orally available analogue of ABT-737, promising findings from phase I/II clinical trials with Navitoclax have been recorded for its safe tolerance [388] against various types of cancer [389-391]. To date, 34 clinical trial studies have been registered (www.cliniclatrials.gov), of which 17 have been completed and 12 published in depth (Table 10).

As a single agent, it has been tested with CLL (NCT01557777), platinum resistant ovarian cancer
(NCT02591095) and in combination with other drugs, against hematological and solid cancers [192] such as Rifampicin (NCT01121133, [398]), and Ketoconazole (NCT01021358). Results for some of these trials are eagerly awaited. Among the hematological neoplasms, Navitoclax was evaluated in combination with Rituximab in phases I/II clinical trial studies, conducted in patients with relapsed or refractory CD20+ lymphoid malignancies and patients with B-cell CLL with no prior treatment (NCT01087151), respectively. Here, combinations of Navitoclax and Rituximab were tolerated and showed significant synergistic effects in both settings $[399,400]$. Additionally, Navitoclax showed encouraging disease stabilization properties as a single therapeutic or in combination with Gemcitabine in NSCLC and solid tumor patients, although side effects remained as on-going concerns. In this context, and more recently among hematological cancer patients, Venetoclax was evaluated in combination with Navitoclax (NCT03181126) to determine safety and pharmokinetic properties in a phase I trial for relapsed or refractory ALL or LL patients and which offered more encouraging outcomes, highlighting promising potential for $\mathrm{BH} 3$ mimetics to be used in combination with each other in addition with pre-existing therapeutics.

\section{-Gossypol}

AT-101, the orally available enantiomer of racemic Gossypol, showed acceptable anti-cancer properties in a range of models (Table 11), and which led to it being evaluated further in clinical trials.

To date, 29 clinical trial studies have been registered (www.clinicaltrials.gov), 17 completed and 5 of which have been published in detail (Table 11). As a monotherapeutic, it has been tested in several phase II trials addressing its efficacy in NSCLC (NCT00773955),

Table 10 Selected phase I clinical trials conducted with Navitoclax as a single or combined therapeutic in untreated and pre-treated patients with Docetaxel (DOC), Erlotinib (ERLO), Gemcitabine (GEM), Carboplatin (CARB), Paclitaxel (PAC), Etopiside (ETOP), Cisplatin (CISP) against Advanced Solid Tumors (AST), non-small cell lung cancer (NSCLC), Prostate Cancer (PC), Squamous cell carcinoma (SCC) and lymphoid malignancies (LM) for Maximum Tolerated Doses (MTD) outcomes

\begin{tabular}{llllllll}
\hline Navitoclax & Combined & Patients & Disease & Outcomes & ORR & Stabilized & Ref \\
\hline NCT00888108 & DOC & 39/41 Pre-Treated & AST & MTD & $4 / 35$ PR & - & [392] \\
NCT01009073 & ERLO & - & NSCLC, PC, SCC & MTD & $0 \%$ ORR & $27 \%$ & {$[393]$} \\
NCT00887757 & GEM & Pre-Treated & $\underline{\text { ST }}$ & MTD & $0 \%$ ORR & $54 \%$ & {$[394]$} \\
NCT00891605 & CARB/PAC & - & $\underline{\text { ST }}$ & TERMINATED & $5.3 \%$ PR & $36.80 \%$ & {$[395]$} \\
NCT00878449 & ETOP/CISP & Untreated (14 days) & $\underline{\text { SCLC }}$ & MTD & - & - & {$[396]$} \\
NCT00445198 & -single- & Pre-Treated & NSCLC, ST & 0\% & $1 / 47$ PR & $22.8 \%(13 \mathrm{~m})$ & {$[390]$} \\
NCT00406809 & -single- & - & LM & MTD & $10 / 46$ PR & - & {$[389,397]$}
\end{tabular}

The clinical trials reference numbers highlighted in bold (left column), the evaluation of a single therapy alone is highlighted by -single-. Objective Response Rates (ORR) and Partial Responses (PR) are expressed as responding patient numbers/numbers assessed, or as percentages (\%). Disease stabilization (Stabilized) effects (as percentage responders) are highlighted in months $(\mathrm{m})$. The corresponding references for the studies are highlighted in the column on the right (Ref) 
Table 11 Selected phase I-II clinical trials conducted with AT-101 as a single (-single-) or combined therapeutic on untreated/pretreated patients with Carboplatin (CARB), Paclitaxel (PAC), Cisplatin (CIS), Etoposide (ETOP), Luteinizing Hormone Receptor Hormone (LHRH) agonist, Bicalutamide (BIC) against Advanced Solid Tumors (AST), Giant Cell Glioblastoma (GCG), Adrenocortical (ADC), Solid Tumors (ST), Small Cell lung Cancer (SCLC) and Metastatic Prostate Cancer (MPC) are highlighted for Maximum Tolerated Doses (MTD). Side effects are abbreviated as ADP (Abdominal Pain), Neut (Neutropenia), Throm (Thrombocytopenia), Gastrointestinal symptoms (GI), Fatigue (FAT), Anemia (Anem) and Nausea (Nau). Objective Response Rates (ORR), Complete Responses (CR), Partial Responses (PR), Prostate-Specific Antigen levels (PSA) and percentage patients (\%) from the whole group experiencing disease stabilization effects are also highlighted (Stab.). The clinical trials reference numbers are highlighted in bold (left column), and the corresponding references highlighted in the column on the right (Ref). Unavailable data is highlighted by '-'

\begin{tabular}{|c|c|c|c|c|c|c|c|c|c|}
\hline AT-101 & Phase & Patients & Patients & Combined & Disease & Adverse Effects & ORR & Stab. & Ref \\
\hline NCT00891072 & I & 24 & Pre-treated & CARB/PAC & AST & ADP/Neut/Throm & 4.16\% CR; $16.66 \%$ PR & $33 \%$ & [401] \\
\hline NCT00540722 & $\|$ & 56 & Untreated (3 wks) & -single- & GCG & Gl/FAT & - & - & - \\
\hline NCT00848016 & $\|$ & 29 & - & -single- & ADC & Anem/Naus/FAT & - & - & - \\
\hline NCT00544596 & । & 27 & Untreated (4 wks) & CIS/ETOP & $\mathrm{ST} / \mathrm{SCLC}$ & - & - & - & - \\
\hline NCT00773955 & $\|$ & 14 & Pre-treated & -single- & SCLC & Anem/Gl & $0 \%$ CR; 0\% PR & - & - \\
\hline NCT00666666 & $\|$ & 55 & Untreated (4 wks) & $\mathrm{LHRH} / \mathrm{BIC}$ & MPC & Anem/Gl/AT & 18-60\% Decreased PSA & - & - \\
\hline
\end{tabular}

adrenocortical cancer (NCT00848016) and giant cell glioblastoma (NCT00540722) with significant adverse gastrointestinal effects (such as diarrhoea and nausea) or thrombocytopenia and neutropenia, with little significant benefits. Nevertheless, testing has advanced to determine efficacy in relation to genetic biomarker expression, such as the Bcl-2 family of BH3-proteins and the results for which are eagerly awaited (NCT00540722). AT-101 has also been tested in combined therapeutic approaches in trials for solid tumors and hematological cancers such as SCLC (NCT00397293, NCT00544596), NSCLC (NCT00544960), CLL (NCT00286780), relapsed or refractory SCLC (NCT00397293) and with androgen ablation therapy in PC (NCT00666666). While some of the studies are yet to report their findings, AT-101 with androgen ablation did encouragingly reduce circulating levels of Prostate-Specific Antigen (PSA) in PC patients (NCT00666666). Based on AT-101 binding Mcl1, further work in this area may address how this agent synergizes with other well-established (or promising) BH3-mimetics, or in overcoming enhanced Mcl1-expression mediated Venetoclax resistance.

\section{-Obatoclax}

As an antagonist that binds the BH3-domain of apoptotic proteins, Obatoclax has been reported to induce cell death, cell arrest and autophagy in leukemia and lymphoma cell lines [190, 402-407]. To date, 20 clinical trials for Obatoclax have been registered (www.clinicaltrials. gov), of which 12 have been completed, and 8 of which have been described in detail (Table 12).

Obatoclax has been tested in a number of phase I/ II trials against SCLC (NCT00682981, NCT00521144), NSCLC (NCT00405951), Hodgkin's Lymphoma
(NCT00359892), MCL (NCT00407303), CLL (NCT00600964), and AML (NCT00684918), with marginally-encouraging outcomes as a single agent or in a limited number of combined studies with common side effects. This may be attributed to it beneficially targeting $\mathrm{Bcl}-\mathrm{xL}$ (in addition to $\mathrm{Bcl}-2$ and Mcl1) to differing degrees (at a fixed dose), albeit with limited clinical benefits (such as disease stabilization) as a dual-acting drug. Alternatively, in utilizing a combined therapeutic approach, mono-therapeutics (exclusively specific for Bcl-2, Bcl-xL or Mcl1), are being seen to have the advantage of being optimized in doses, to target each of these components more accurately based on the degree of resistance encountered, and may (in some respects) be a more fruitful approach [191, 192, 410, 416, 417]. Based on the benefits arising from Obatoclax stabilizing the progression of certain cancers as a mono-therapeutic, there does therefore exist some potential in how it may be optimized further for this purpose, and possibly thereafter in combined therapeutic regimens.

\section{SMAC-mimetics}

As an important emerging therapeutic group with great potential based on pre-clinical studies, 10 clinical studies for the Smac-mimetic LCL-161 have been registered to date (www.clinicaltrials.gov), of which 6 have been completed and 3 of which have been described in detail (Table 13).

Additionally, phase I studies of TL32711, LCL-161 and HGS1029 Smac-mimetics have been conducted (orally and intravenously), in patients with solid tumors and lymphoma, revealing mixed outcomes ranging from being well-tolerated to inducing cytokine release syndrome. As expected, the latter can be explained through clinical 
Table 12 Selected phase I-II clinical trials conducted with Obatoclax as a single (-single-) or combined therapeutic in untreated/ pre-treated or non-refractory(-)/refractory (Refrac) patients with Carboplatin (CARB), Etoposide (ETOP) or Topotecan (TOPOT) against extensive-stage small cell lung cancer (es-SCLC), Myelodysplastic Syndrome (MDS), Hodgkin's Lymphoma (HL), Myelofibrosis (MFS), advanced Chronic Lymphocytic Leukemia (a-CLL), and Hematologic Malignancies (HM). Adverse effects are abbreviated as Neut (Neutropenia), Anem (Anemia), Euph (Euphoria), Dizz (Dizziness), Naus (Nausea), Atax (Ataxia) and Throm (Thrombocytopenia). Disease stabilization effects on patient numbers (expressed as a percentage (\%) of the whole group or as positive responders/group size) are highlighted in weeks (>wks). Unavailable data for disease stabilization effects is highlighted by '- - . The clinical trials reference numbers highlighted in bold (left column) and their corresponding references highlighted in the columns on the right (Ref)

\begin{tabular}{|c|c|c|c|c|c|c|c|c|}
\hline Obatoclax & Phase & Patients & Refrac & Combined & Disease & Adverse Effects & Stabilization & Ref \\
\hline NCT00684918 & $|/| \mid$ & Untreated & - & -single- & AML & Neut & $4 / 19$ for 11 cycles & [408] \\
\hline NCT00682981 & $\|$ & Untreated & - & CARB/ETOP & es-SCLC & Neut/Anem & - & [409] \\
\hline NCT00413114 & $\|$ & Untreated & - & -single- & MDS & Euph/Naus & $50 \%$ (> 12 wks $)$ & [410] \\
\hline NCT00359892 & $\|$ & - & Yes & -single- & $\mathrm{HL}$ & Euph/Dizz & $38 \%$ (> 8 wks) & [411] \\
\hline NCT00521144 & $\|$ & Pre-treated & Yes & TOPOT & SCLC & Throm/Neut/Anem/Atax & 56\% (Phase II) & [412] \\
\hline NCT00360035 & $\|$ & Pre-treated & - & -single- & MFS & Atax/Anem/Throm & - & [413] \\
\hline NCT00600964 & $|/| \mid$ & Pre-treated & Yes $(22 / 26)$ & -single- & $\mathrm{a}-\mathrm{CLL}$ & $\begin{array}{l}\text { Atax/Euph/Anem/ } \\
\text { Throm }\end{array}$ & - & [414] \\
\hline NCT00438178 & । & N/A & Yes & -single- & $\mathrm{HM}$ & Neut/Anem/Throm & - & [415] \\
\hline
\end{tabular}

Table 13 Selected phase I-II clinical trials conducted with LC-161 as a single (-single-) or combined therapeutic in pre-treated or refractory (Refrac) patients with Paclitaxel (PAC), against Advanced Solid Tumor (AST) diseases (Dis.) and Outcomes for Maximum Tolerated Doses (MTD) are highlighted. Adverse effects (Adv. Effects) are highlighted as Neut (Neutropenia), Gastrointestinal symptoms $(\mathrm{Gl})$, Diarrhoea (Diar), Nausea (Nau), Vomiting (Vom) and Anemia (Anem). Objective Response Rates (ORR), Partial Responses (PR), Progressive Disease (PD) and disease stabilization effects (Stabil.) are highlighted as percentage (\%) positive-responders. The clinical trials reference numbers highlighted in bold (left column) and their corresponding references highlighted in the columns on the right (URL/Ref). Biomarker assessments (Bio.M) are highlighted and unavailable data is highlighted by'-'

\begin{tabular}{|c|c|c|c|c|c|c|c|c|c|c|c|}
\hline LCL-161 & Phase & Patient & Refrac & Combined & Dis. & Outcomes & Adv. Effects & ORR & Stabil. & Bio.M & URL/Ref \\
\hline NCT01240655 & $\mathrm{lb}$ & Pre-treated & Yes & PAC & AST & MTD & Neut/Gl & $27.6 \%$ PR; $25 \%$ PD & $36.8 \%$ & - & www.novctrd.com \\
\hline NCT01968915 & $|/| \mid$ & - & - & $\begin{array}{l}\text {-single-/ } \\
\text { PAC }\end{array}$ & AST & - & Neut/Diar & DISC. & - & - & www.novctrd.com \\
\hline NCT01098838 & $|/| \mid$ & Pre-treated & - & -single- & AST & MTD & $\begin{array}{l}\text { Naus/Nom/ } \\
\text { Anem }\end{array}$ & $0 \%$ ORR & $19 \%$ & CIAP & [418] \\
\hline
\end{tabular}

biomarker studies showing the degradation of cIAP and up-regulation of NF-kB activation and pro-inflammatory cytokine expression [418-421]. Further optimization of such approaches may help overcome such side effects. Nevertheless, LCL-161 does exhibit disease stabilization (Table 13), in relation to other initial phase I trials evaluating alternative Smac-mimetics, that show encouraging evidence of significant anti-tumor activity, as seen with GDC-0917 as a monotherapy for patients with OC or MALT-lymphoma, HGS1029 against colon cancer and Debio1143 against melanoma metastases [418]. From the perspective of a combined therapeutic, the effects of Smac-mimetics can be enhanced further upon the costimulation of cells with death inducing ligands such as TNF- $\alpha$ and TRAIL, and is also an area being developed through inducing their expression with oncolytic viruses and immunomodulatory adjuvants [422].

\section{Venetoclax (ABT-199)}

As the most promising therapeutic from the BH3-mimetics group in targeting the Bcl-2-BAX or -BAK axis of apoptosis regulation, to date 331 clinical trials have been registered testing Venetoclax, and of which 27 have been completed (www.clinicaltrials.gov). As seen in Tables 12, 14 studies have been published in detail, where Venetoclax was seen to exhibit a relatively good safety profile, leading to its evaluation in trials with combined agents and in patients with specific genetic biomarker aberrations.

As seen, Venetoclax is showing itself to be a very promising therapeutic, against $\mathrm{Bcl}$-2-dependent cancer cells such as CLL, acute leukemias, breast cancer, mycdriven lymphomas [293-295], and through successful phase I-III trials for acute myeloid leukemia (AML), CLL, MM and non-Hodgkin's lymphoma (NHL) [296], it 
Table 14 Selected phase I-III clinical trials conducted with Venetoclax (V) as a single (-single-) or combined therapeutic in untreated/ pre-treated or non-refractory(-)/refractory patients (Refrac) with Mivebresib (Miv), Rituximab and Cyclophosphamide, Doxorubicin, Vincristine, and Prednisone (R-CHOP), Bendamustine (BEND) Rituximab (RIT) Obinutuzumab (OBIN), Cytarabine (CYT), Ibrutinib (IBU) Rituximab (RIT), Bortezomib (BORT) and Dexamethasone (DEX) against Acute Myelogenous Leukemia (AML), Large B-cell Lymphoma (L-BCL), Follicular non-Hodgkin's Lymphoma (FnHL), Chronic Lymphocytic Leukemia (CLL), Non-Hodgkin's Lymphoma (NHL), Multiple Myeloma (MM). Objective Response Rates (ORR), Complete Responses (CR) and Partial Responses (PR), expressed as percentage responders (\%) are highlighted for disease progression (R/R) patients against R/R with 1/L (1 year treatment) patients. The clinical trials reference numbers highlighted in bold (left column) and the corresponding references highlighted in the column on the right (Ref). Studies where patients were profiled (and their numbers) are highlighted in the Biomarkers column as percentages (\%) and '-'indicates no profiling

\begin{tabular}{|c|c|c|c|c|c|c|c|c|}
\hline Venetoclax & Phase & Combined & Patients & Refrac & Disease & ORR, CR, PR & Biomarkers & Ref \\
\hline NCT02391480 & $|/| \mid$ & Miv & Pre-treated & Yes & AML & $6.66 \% \mathrm{CR} ; 6.66 \% \mathrm{PR}$ & $\begin{array}{l}\text { HEXIM1, DCXR, ITD/ } \\
\text { TKD, PTPN11 }\end{array}$ & {$[423,424]$} \\
\hline NCT02055820 & $\|$ & $\mathrm{R}-\mathrm{CHOP}$ & Pre-treated & - & L-BCL & - & $\mathrm{BCl}-2, \mathrm{MYC}$ & [425] [426] \\
\hline NCT02187861 & $\|$ & $\begin{array}{l}\text { BEND(B)/ } \\
\text { RIT (R) }\end{array}$ & Untreated (28d) & Yes & $\mathrm{FnHL}$ & $\begin{array}{l}75 \% V+B R ; 69 \% B R \\
\text { (untreated) } \\
4 \% V+R \text { (non- } \\
\text { Refrac) + } 19 \% V+R \\
\text { (Refrac) }\end{array}$ & $\begin{array}{l}\mathrm{BCl}-2 / \\
\mathrm{Mcl} 1\end{array}$ & [427] \\
\hline NCT02265731 & $\|$ & RIT (R) & Pre-treated & Yes & CLL & $\begin{array}{l}100 \%(\mathrm{~V}, \mathrm{ORR}) ; 66.7 \% \\
(\mathrm{~V}+\mathrm{R}, \mathrm{ORR}) \\
16.7 \%(\mathrm{~V}, \mathrm{CR})+50 \% \\
(\mathrm{~V}+\mathrm{R}, \mathrm{CR})\end{array}$ & - & {$[428]$} \\
\hline NCT01685892 & $\mathrm{Ib}$ & OBIN & Untreated & Yes & CLL & $\begin{array}{l}95 \%(\mathrm{R} / \mathrm{R}, \mathrm{ORR}) ; 100 \% \\
(1 / \mathrm{L}, \mathrm{ORR}) \\
37 \%,(\mathrm{R} / \mathrm{R}, \mathrm{CR})+78 \% \\
(1 / \mathrm{L}, \mathrm{CR})\end{array}$ & $\begin{array}{l}\text { IGHV, P53, B2 MG, } \\
\text { CD38 }\end{array}$ & [429] \\
\hline NCT02287233 & $|\mathrm{b} /| \mid$ & CYT & Untreated & - & AML & $62 \% C R$ & - & [430] \\
\hline NCT02756897 & $\|$ & IBRUTINIB & Untreated & - & CLL & $88 \% C R$ & - & [431] \\
\hline NCT01594229 & $\mathrm{lb}$ & BEND/RIT & - & Yes & $\mathrm{NHL}$ & $\begin{array}{l}65 \% \text { ORR (30\%, CR; } \\
35 \%, \text { PR) }\end{array}$ & $\mathrm{BCl}-2$ & [432] \\
\hline NCT03755947 & III & RIT & Pre-treated & Yes & $\begin{array}{l}17 p-/ T P 53-/ / G H V- \\
C L L\end{array}$ & $\begin{array}{l}92.3 \% \text { ORR; }(17.48 \% \text {, } \\
\text { CR) }\end{array}$ & - & [433-439] \\
\hline NCT01794507 & $\mathrm{Ib}$ & BORT/DEX & Pre-treated & Yes & MM & $67 \%$ ORR & Bcl-2 Bcl-xL, Mcl1, & {$[440]$} \\
\hline NCT01889186 & $\|$ & -single- & - & Yes & del17p-CLL & $70 \%$ ORR & 17P del (50.3\%) & {$[441-443]$} \\
\hline NCT01994837 & $\|$ & -single- & Pre-treated & - & AML & $19 \%$ ORR (6\% CR) & $\begin{array}{l}\text { BCl-2, BCl-XL, BH3 } \\
\text { Profiling, Mcl1 }\end{array}$ & {$[444]$} \\
\hline NCT01328626 & । & -single- & - & Yes & CLL & $79 \%$ ORR (20\% CR) & 17Pdel & {$[435,443]$} \\
\hline
\end{tabular}

was ultimately awarded US Food and Drug Administration (US FDA) and European Medicines Agency (EMA) approval for treating CLL patients harboring the $17 \mathrm{p}$ or p53 mutations [445].

As a mono-therapeutic, Venetoclax has also been reported to be effective against other lymphomas with high Bcl-2 expression levels, as in MCL, myeloma, refractory AML [444], follicular lymphoma and some diffuse large B-cell lymphomas [446], whereby the dose administered could be correlated with expression levels of Mcl1 and Bcl-xL [447]. Over the last 3 years a number of follow-up trials have been published, aimed at defining its use against drug resistance, with some very encouraging outcomes based on its combined use with other therapeutics such as DNA damaging agents, antiCD20 antibodies (such as Rituximab), hyper-methylating agents, kinase inhibitors, Mdm2 inhibitors, proteasome inhibitors, and in conjunction with inhibitors targeting the anti-apoptotic proteins Bcl-xL and Mcl1 [448]. At a time when there are a plethora of on-going clinical trials involving Venetoclax (www.clinicaltrials.gov), its combined use with Rituximab is showing some very promising outcomes with complete remissions recorded for $51 \%$ of relapsed CLL patients [449], and it is also leading the way for use with patients encoding specific genetic biomarker aberrations (NCT02391480, NCT02055820, NCT02187861, NCT01685892, NCT01594229, NCT01794507, NCT01994837, NCT01328626), and where serious side effects (such as neutropenia and thrombocytopenia) are being managed with the growth factor prophylaxes (NCT02265731, NCT02055820, NCT01889186). Collectively, such findings encouragingly highlight the potential of Venetoclax as a developing model for the treatment of hematological cancers, 
and thus paving the way for its further testing on solid tumors.

\section{Mcl1-inhibitors}

Although genetically elevated Mcl1 levels have been reported in many tumor types [26], it has been implicated in therapeutic resistance of breast and lung cancers [450, 451], with some studies showing that Mcl1 expression can mediate resistance to Navitoclax or Venetoclax [70, 99, 452], Gemcitabine, Vincristine and Taxols [453-455]. To date 36 clinical trials have been registered utilizing Mcl1 inhibitors (www.clinicaltrials.gov.uk), amongst which 10 have been completed, 2 withdrawn, 4 terminated and 8 are still recruiting. Of the completed trials related to targeting the Mcl1 protein (Table 15), S64315 has been tested as a single agent against MM and DLBCL (NCT02992483) in untreated relapsed/refractory patients to establish maximum tolerated doses and the results for which are to be published.

Similarly, trials for S64315 efficacy have also been conducted in AML and MDS patients, and which showed no significant benefits outside of side effects such as nausea and familial neutropenia (NCT02979366). Consequently, concerns regarding the safety of Mcl1 inhibition as a single agent, have arisen and are founded on the dependency of Mcl1 expression for the normal survival and growth of cells, as seen for mouse cardiomyocytes [456], hepatocytes [457] and neurons [458]. In support of this viewpoint, $\mathrm{Mcl1}^{+/-}$mice should mimic a phenotype consistent with $50 \%$ inhibition of Mcl1, but they appear normal and healthy, thus supporting the belief that Mcl1 may also function independently of BH3-domain protein binding and regulation during cellular death [321, 459]. Another challenge for the development of specific Mcl1 inhibitors has emerged from the rigidity of the Mcl1 protein hydrophobic pocket and competitiveness for this posed by alternative high-affinity endogenous protein binding partners [460]. Nevertheless, several highly potent (sub-nanomolar) and selective inhibitors have emerged very recently, and one of which (UMI-77) shows excellent potential against pancreatic cell lines in vitro and in xenograft pre-clinical models [461]. Similarly, pre-clinical findings for the inhibitor S63845 have been very impressive [74], against several cancer types including melanoma, leukemia, lymphoma, and other solid cancers either as a single or combined agent, and further work here will indeed help in extending these findings towards clinical studies.

In summary, while serious side effects and solubility issues had been reported for the founding therapeutic member ABT-737, as seen from the findings presented in Tables 10,11,12,13,14,15, derivatives of this appear to be showing incredible promise in treating hematological and solid cancers. With concerted efforts being made in the clinic to address side effects, the members that are showing steady progress from phases I to III, include Venetoclax and Obatoclax, with progress from studies evaluating Mcl1- and Smac- mimetics (or inhibitors) maintaining steady momentum. When coupled with evaluating patients for genetic biomarker mutation profiling, a very clear and interesting picture is coming into focus with regards to how some of these mimetics may have greater efficacy and potential in a personalized medicine context, and as encouragingly seen from clinical trials highlighted in Table 14.

\begin{abstract}
Mimetics: current considerations for solubility and delivery In light of the above developing areas for therapeutic mimetics, key areas for therapeutic delivery have also been given greater consideration, particularly in response to solubility and delivery limitations arising from the ABT-737 paradigm. Classically, while therapeutic affinity for the target protein is of paramount importance when designing an intervention strategy, additional factors affecting therapeutic availability, longevity, toxicity, and penetrability are also being given greater collective importance. In the next section, we selectively outline and evaluate the recent progress that has been reported in the areas of SMI and peptide therapeutics delivery, with a view to highlighting their usefulness for mimetic bioavailability and solubility, which (from the ABT-737 paradigm) were serious considerations that hindered the immediate evaluation of such a promising therapeutic.
\end{abstract}

Table 15 Selected phase I clinical trials conducted with MIK655 or S64315 as a single (S) therapeutic, on untreated, and refractory (Refrac) diseases, such as Multiple Myeloma (MM), Diffuse Large Cell B-Lymphoma (DLBCL), Acute Myeloid Leukemia (AML) and Myelodysplastic Syndrome (AST) patients, for Maximum Tolerated Dose (MTD) are highlighted. Adverse effects (Adv. Effects) are highlighted as Nausea (Nau), Familial Neutropenia (F-Neut) and Diarrhoea (Diar). The clinical trials reference numbers are highlighted in bold (left column) and the Objective Response Rates (ORR) expressed as the percentage of patients who responded positively (\%). Unavailable data is highlighted by'-'

\begin{tabular}{lllllllll}
\hline MIK655/S64315 & Phase & Single & Patients & Refrac & Disease & Outcomes & Adv. Effects & ORR \\
\hline NCT02992483 & I & S & Untreated & Yes & MM, DLBCL & MTD & - & Unpublished \\
NCT02979366 & I & S & Untreated (14days) & Yes & AML, MDS & MTD & Nau/F-Neut/Diar & O\% ORR \\
\hline
\end{tabular}


As many SMIs are hydrophobic, which may present solubility and bioavailability challenges, the recently demonstrated successes of cell-penetrating peptide (CPP) nanoparticles [462] or nanofibers [463, 464] are emerging as synergistic alternatives for therapeutic solubilization and the delivery of therapeutic cargo. Briefly, the combined use of monomeric CPP amphiphilic peptides with cholesterol can self-assemble, forming a shell-structured nanoparticle, that contains a hydrophobic cholesterol core and a hydrophilic cationic exterior, which can enhance solubility, loading, delivery, and uptake of potential therapeutics [462]. Similarly, the potential of supramolecular nanofiber technology in this context is evidenced through them being able to enhance the incorporation of Paclitaxel from 6.8 to 41\% [465], from a self-assembling amphiphilic peptide monomer [466]. Moreover, such applications can be extended to incorporate anti-inflammatories [467], multi-drug combinations [468] and imaging agents [469, 470], which collectively highlight the potential of such approaches.

While, CPPs can enhance cargo delivery of drugs using nanostructures [462, 471, 472], reduced specificity, resulting toxicity and reduced half-life can present challenges, as with most delivery systems of this nature [473, 474]. In the context of delivering BH3-mimetics, one good example which demonstrates how some of these issues of specificity and delivery can be overcome, was published by Schnorenberg et al. (2019), who utilized a BIM BH3-mimetic peptide amphiphile nanostructure to facilitate uptake for triggering the death of Hela and MEF cells [475]. Interestingly, a cathepsin B cleavage signal was also incorporated between the mimetic and hydrophobic tail to permit release of the mimetic at the site of enhanced ECM turnover, or within cells following endosomal and lysosomal uptake [475].

Importantly, the use of supra-molecular peptide delivery systems is being seen to offer certain advantages over classical delivery systems, such as high-concentration delivery of peptides, stabilization of peptide secondary structure, protection from proteolysis within the circulatory system, increased half-life, delivery of multiple therapeutics and enhanced uptake to the endosomal and lysosomal compartments [476, 477]. While carrier peptides or CPPs can be utilized to help aide solubility and penetrability, an alternative targeting approach worth highlighting is the use of Elastin-like polypeptides (ELPs), which can form aggregates when heated externally and which can selectively accumulate in tumors [478-480]. Such an approach exploits the increased permeability of tumor vasculature during regional hyperthermia, during which a greater accumulation of macromolecular drug carriers loaded with single or combined therapeutics is permitted [481-483]. This permits enhanced cytotoxicity
[484], which can be optimised further through CPP tagging for delivery to cells in vitro or in vivo [485-488]. While some peptides may require certain conformations to achieve full inhibitory activity or cellular penetrability, $\mathrm{pH}$ dependent membrane insertion (pHLIPS) may offer additional potential benefits, from the perspective of correcting structurally disorganized peptide therapeutics to adopt a favorable $\alpha$-helical structure during their delivery and thereafter [489-491].

Lastly, the use of phospholipids [492] for self-assembling micelles and the delivery of safe and non-immunogenic, hydrophobic drugs such as cyclosporine A [493], Paclitaxel [494] and peptides [495], can minimize the degradation or aggregation of cargo [496-499]. Encouragingly, such approaches can enhance therapeutic efficacy through reduced extravasation from the circulation, while simultaneously reducing adverse off-target effects $[495,500]$. However, such an approach does come with limitations that cannot go ignored, due to potentially diminished availability of the helical peptide therapeutic moiety, through masking and immunogenic effects from PEG, or limitations in peptide cargo lengths of 17-36 aa $[501,502]$. Nevertheless, as a way of highlighting the potential of this approach, Gossypol loaded micelles combined with A549 cells and radiation therapy in a xenograft mouse model [503], showed $7 x$ greater efficacy against tumors than Gossypol alone [504]. Moreover, biomimetic poly(lactic-coglycolic acid) (PLGA) combined with red blood-cell membrane ( $\mathrm{RBCm})$ as nanoparticles loaded with Obatoclax mesylate for the treatment of non-small-cell lung cancer, also showed significant success in prolonging drug circulation in the presence of a reduced immune response against the particles [505].

\section{Conclusions}

In summary, while ABT-737 was discovered as an authentic BH3-mimetic, derivatives such as Navitoclax and Venetoclax hold great potential in treating hematological cancers and even solid tumors when administered with classical and conventional anti-cancer drugs, and the evidence for which is firmly grounded on basic research efforts at the pre-clinical level. In this context, Smac-mimetics have also emerged as being promising candidates for treating a range of cancer types, as seen from their combined compatibility with a broader range of anti-cancer drugs in pre-clinical models. However, the most promising potential therapeutics in pre-clinical models appear to be the Mcl1 inhibitors, particularly when administered in combination with Venetoclax, Navitoclax, death inducing ligands and conventional anti-cancer drugs.

Through extending such findings by way of clinical trials, the therapeutic efficacy of the most promising 
anti-cancer drugs are coming into fruition, either as single or as combined agents. While resistance has always served to hinder the development of many therapeutics for cancer, the off-target effects of such agents are becoming increasingly clear, and in some instances are also being harnessed through the development of dual-activity inhibitors, or as agents that can be synergistically utilized to overcome any resistance effects. From the above findings, the best example of this is highlighted by the effectiveness of Mcl1 inhibitors, when combined with the drugs Navitoclax or Venetoclax as co-therapeutics, and the findings from which are also being effectively aligned with specific genetic biomarkers of interest. Lastly, of emerging interest, in this context, are the BH3-mimetics Obatoclax and Gossypol, and Smac-mimetics, the clinical importance of which are eager awaited.

As the focus of this article has revolved around the regulation of the intrinsic arm of apoptosis, the effects of the above mimetics and inhibitors towards other cell deathinducing off-target effects, cannot be ignored. Such an assertion arises from what contribution these therapeutics may offer in minimizing the protective effects of prosurvival proteins, associated with the ER stress-response [403, 506], autophagy [507, 508], necroptosis [406] or cell cycle deregulation [509, 510]. When considered alongside how technologies have developed to improve solubility and the delivery of therapeutics, and thereby improving their efficacy, the initial limitations surrounding candidates (such as ABT-737), based on lack of solubility and availability, can be addressed with greater optimism. Such developments indeed offer greater certainty in pursuing mimetics as therapeutics and which follow a strongly-validated paradigm. From an equally important perspective, the presence of clinical side effects, such as thrombocytopenia have always appeared as a major source of concern. As mentioned, such effects can be minimized through molecular approaches, as in the instance of re-engineering Navitoclax to DT2216, and which acts through degrading Bcl-xL [383], thus reducing its off-target effects. Moreover, complimentary approaches through the use of prophylaxes are also being implemented, as effective management strategies within the clinic.

When considered together, the previous 20-30 years of mimetics research have indeed come a long way, whilst occupying a vast area of development in cancer treatment, and which lay very strong technological foundations for the future development of novel single-, combined- or dual- action therapeutics, with personalized medicine being well positioned at the forefront of such endeavors.

\section{Abbreviations}

ALL: Acute lymphoblastic leukaemia; AML: Acute myelogenous leukemia; BAX: BCl-2-associated protein X; BAK: BCl-2 antagonist/killer; BC: Breast Cancer; BOK: $\mathrm{BCl}-2$ ovarian killer; $\mathrm{BCl}-2$ : $\mathrm{B}$ cell lymphoma-2; $\mathrm{BCl}-\mathrm{xL}$ : $\mathrm{B}$ cell lymphoma extra-large; $\mathrm{BH}$ domain: $\mathrm{BCl}-2$ homology domain; $\mathrm{Bid}$ : $\mathrm{BCl}-2$ interacting domain death agonist; Bim: $\mathrm{BCl}-2$ interacting mediator of cell death; BIR: Baculovirus IAP Repeat; CAD: Caspase-activated DNAase; CLL: Chronic lymphocytic leukaemia; CPP: Cell penetrating peptide; DLBCL: Diffuse large B-cell lymphoma; ER: Endoplasmic reticulum; HNSCC: Head and neck squamous cell carcinoma; Mcl1: Myeloid cell leukemia-1 protein; EGF-R: Epidermal growth factor-receptor; GC: Gastric Cancer; CIAP: Cellular inhibitor of apoptosis; MCL: Mantle cell lymphoma; MPC: Mitochondrial pore complex; MOMP: Mitochondrial outer membrane permeabilization; NF-kB: Nuclear factor kappa B; NHL: Non-Hodgkin's lymphoma; NSCLC: Non-small cell lung cancer; MM: Multiple myeloma; PARP: Poly ADP-ribose polymerase; PC: Prostate Cancer; PROTAC: Proteolysis targeting chimera; pHLIPS: pH-Low Insertion Peptide; Puma: p53-upregulated modulator of apoptosis; SAHBs: Stabilized alpha-helix of BCL-2; SCLC: Small cell carcinoma; Smac/DIABLO: Second mitochondria-derived activator of caspases; SMI: Small molecule inhibitor; T-ALL: T-cell acute lymphoblastic leukaemia; TNF-a: Tumor necrosis factor-alpha; TRAIL: Tumor necrosis factor-related apoptosis-inducing ligand.

\section{Authors' contributions}

Conception, research theme and efforts, writing, graphics, and text layout were formulated by SMS and PAT. Editing and discussions (ONFC, MVK and AAZ). The author(s) read and approved the final manuscript.

\section{Funding}

This work was funded by the 'University of Surrey and University of Surrey Health Partners'.

\section{Availability of data and materials}

All data and materials cited herein are available upon request.

\section{Declarations}

Ethics approval and consent to participate

Not applicable.

Consent for publication

All Authors consent to the submission and publication of this manuscript.

Competing interests

The authors highlight no competing interests.

\section{Author details}

${ }^{1}$ University of Surrey, Guildford, UK. ${ }^{2}$ Sechenov First Moscow State Medical University, Moscow, Russian Federation. ${ }^{3}$ University of Manchester, Manchester, UK. ${ }^{4}$ Lomonosov Moscow State University, Moscow, Russian Federation.

${ }^{5}$ Sirius University of Science and Technology, Sochi, Russian Federation.

Received: 8 September 2021 Accepted: 26 October 2021

Published online: 09 November 2021

\footnotetext{
References

1. Delbridge $A R$, Strasser $A$. The BCL-2 protein family, BH3-mimetics and cancer therapy. Cell Death Differ. 2015;22(7):1071-80.

2. Adams JM, Cory S. The BCL-2 arbiters of apoptosis and their growing role as cancer targets. Cell Death Differ. 2018;25(1):27-36.

3. Ashkenazi A, Fairbrother WJ, Leverson JD, Souers AJ. From basic apoptosis discoveries to advanced selective BCL-2 family inhibitors. Nat Rev Drug Discov. 2017;16(4):273-84.

4. Soond SM, Kozhevnikova MV, Savvateeva LV, Townsend PA, Zamyatnin AA Jr. Intrinsically connected: therapeutically targeting the cathepsin proteases and the Bcl-2 family of protein substrates as co-regulators of apoptosis. Int J Mol Sci. 2021;22(9):4669.
} 
5. Merino D, Kelly GL, Lessene G, Wei AH, Roberts AW, Strasser A. BH3mimetic drugs: blazing the Trail for new Cancer medicines. Cancer Cell. 2018;34(6):879-91 .

6. Rampino N, Yamamoto H, lonov Y, Li Y, Sawai H, Reed JC, et al. Somatic frameshift mutations in the BAX gene in colon cancers of the microsatellite mutator phenotype. Science. 1997;275(5302):967-9.

7. Zhang M, Zheng J, Nussinov R, Ma B. Oncogenic mutations differentially affect Bax monomer, dimer, and oligomeric pore formation in the membrane. Sci Rep. 2016:6:33340.

8. Shibata MA, Liu ML, Knudson MC, Shibata E, Yoshidome K, Bandey T, et al. Haploid loss of bax leads to accelerated mammary tumor development in C3(1)/SV40-TAg transgenic mice: reduction in protective apoptotic response at the preneoplastic stage. EMBO J. 1999;18(10):2692-701.

9. Kaiser U, Schilli M, Haag U, Neumann K, Kreipe H, Kogan E, et al. Expression of bcl-2--protein in small cell lung cancer. Lung Cancer. 1996;15(1):31-40.

10. Delbridge AR, Grabow S, Strasser A, Vaux DL. Thirty years of BCL-2: translating cell death discoveries into novel cancer therapies. Nat Rev Cancer. 2016;16(2):99-109.

11. Schott AF, Apel IJ, Nunez G, Clarke MF. BCI-XL protects cancer cells from p53-mediated apoptosis. Oncogene. 1995;11(7):1389-94.

12. Findley HW, Gu L, Yeager AM, Zhou M. Expression and regulation of $\mathrm{BCl}$ $2, \mathrm{BCl}-\mathrm{xl}$, and Bax correlate with $\mathrm{p} 53$ status and sensitivity to apoptosis in childhood acute lymphoblastic leukemia. Blood. 1997;89(8):2986-93.

13. Campbell KJ, SWG T. Targeting BCL-2 regulated apoptosis in cancer. Open Biol. 2018;8(5):180002.

14. Shamas-Din A, Brahmbhatt $H$, Leber $B$, Andrews DW. BH3-only proteins: orchestrators of apoptosis. Biochim Biophys Acta. 2011;1813(4):508-20.

15. Lomonosova $\mathrm{E}$, Chinnadurai G. BH3-only proteins in apoptosis and beyond: an overview. Oncogene. 2008;27(Suppl 1):S2-19.

16. Flores-Romero H, Ros U, Garcia-Saez AJ. Pore formation in regulated cell death. EMBO J. 2020;39(23):e105753.

17. Li P, Nijhawan D, Budihardjo I, Srinivasula SM, Ahmad M, Alnemri ES, et al. Cytochrome $c$ and dATP-dependent formation of Apaf-1/ caspase- 9 complex initiates an apoptotic protease cascade. Cell. 1997;91(4):479-89.

18. Schuler M, Green DR. Mechanisms of p53-dependent apoptosis. Biochem Soc Trans. 2001;29(Pt 6):684-8.

19. Ren D, Tu HC, Kim H, Wang GX, Bean GR, Takeuchi O, et al. BID, BIM, and PUMA are essential for activation of the BAX-and BAK-dependent cell death program. Science. 2010:330(6009):1390-3.

20. Villunger A, Labi V, Bouillet P, Adams J, Strasser A. Can the analysis of $\mathrm{BH} 3$-only protein knockout mice clarify the issue of 'direct versus indirect'activation of Bax and Bak? Cell Death Differ. 2011;18(10):1545-6.

21. Cheng EH, Wei MC, Weiler S, Flavell RA, Mak TW, Lindsten T, et al. BCL-2, $B C L-X(L)$ sequester $B H 3$ domain-only molecules preventing $B A X$ - and BAK-mediated mitochondrial apoptosis. Mol Cell. 2001;8(3):705-11.

22. Willis SN, Fletcher Jl, Kaufmann T, van Delft MF, Chen L, Czabotar PE, et al. Apoptosis initiated when $\mathrm{BH} 3$ ligands engage multiple $\mathrm{BCl}-2$ homologs, not Bax or Bak. Science. 2007;315(5813):856-9.

23. Chen HC, Kanai M, Inoue-Yamauchi A, Tu HC, Huang Y, Ren D, et al. An interconnected hierarchical model of cell death regulation by the $\mathrm{BCL}-2$ family. Nat Cell Biol. 2015;17(10):1270-81.

24. Du H, Wolf J, Schafer B, Moldoveanu T, Chipuk JE, Kuwana T. BH3 domains other than Bim and bid can directly activate Bax/Bak. J Biol Chem. 2011;286(1):491-501.

25. Gallenne T, Gautier F, Oliver L, Hervouet E, Noel B, Hickman JA, et al. Bax activation by the $\mathrm{BH}$-only protein Puma promotes cell dependence on antiapoptotic BCl-2 family members. J Cell Biol. 2009;185(2):279-90.

26. Beroukhim R, Mermel CH, Porter D, Wei G, Raychaudhuri S, Donovan J, et al. The landscape of somatic copy-number alteration across human cancers. Nature. 2010;463(7283):899-905.

27. Warr MR, Shore GC. Unique biology of Mcl-1: therapeutic opportunities in cancer. Curr Mol Med. 2008;8(2):138-47.

28. Willis SN, Chen L, Dewson G, Wei A, Naik E, Fletcher Jl, et al. Proapoptotic Bak is sequestered by $\mathrm{MCl}-1$ and $\mathrm{BCl}-\mathrm{xL}$, but not $\mathrm{BCl}-2$, until displaced by BH3-only proteins. Genes Dev. 2005;19(11):1294-305.

29. Zhong Q, Gao W, Du F, Wang X. Mule/ARF-BP1, a BH3-only E3 ubiquitin ligase, catalyzes the polyubiquitination of $\mathrm{MCl}-1$ and regulates apoptosis. Cell. 2005;121(7):1085-95.
30. Nakajima W, Tanaka N. Synergistic induction of apoptosis by p53-inducible Bcl-2 family proteins Noxa and Puma. J Nippon Med Sch. 2007:74(2):148-57.

31. Nakajima W, Tanaka N. Noxa induces apoptosis in oncogene-expressing cells through catch-and-release mechanism operating between Puma and Mcl-1. Biochem Biophys Res Commun. 2011;413(4):643-8.

32. Varadarajan $S$, Vogler $M$, Butterworth $M$, Dinsdale $D$, Walensky LD, Cohen GM. Evaluation and critical assessment of putative MCL-1 inhibitors. Cell Death Differ. 2013;20(11):1475-84.

33. Hussain SR, Cheney CM, Johnson AJ, Lin TS, Grever MR, Caligiuri MA, et al. MCl-1 is a relevant therapeutic target in acute and chronic lymphoid malignancies: down-regulation enhances rituximab-mediated apoptosis and complement-dependent cytotoxicity. Clin Cancer Res. 2007;13(7):2144-50

34. Masilamani AP, Dettmer-Monaco V, Monaco G, Cathomen T, Kuckuck I, Schultze-Seemann S, et al. An Anti-PSMA Immunotoxin Reduces Mcl-1 and $\mathrm{BC} 12 \mathrm{~A} 1$ and specifically induces in combination with the bad-like BH3 Mimetic ABT-737 apoptosis in prostate cancer cells. Cancers (Basel). 2020;12(6):1648.

35. Wu H, Schiff DS, Lin Y, Neboori HJ, Goyal S, Feng Z, et al. lonizing radiation sensitizes breast cancer cells to BCl-2 inhibitor, ABT-737, through regulating Mcl-1. Radiat Res. 2014;182(6):618-25.

36. Oda E, Ohki R, Murasawa H, Nemoto J, Shibue T, Yamashita T, et al. Noxa, a BH3-only member of the $\mathrm{BCl}-2$ family and candidate mediator of $\mathrm{p} 53$ induced apoptosis. Science. 2000;288(5468):1053-8.

37. Nakano K, Vousden KH. PUMA, a novel proapoptotic gene, is induced by p53. Mol Cell. 2001;7(3):683-94.

38. Yu J, Zhang L, Hwang PM, Kinzler KW, Vogelstein B. PUMA induces the rapid apoptosis of colorectal cancer cells. Mol Cell. 2001;7(3):673-82.

39. Du C, Fang M, Li Y, Li L, Wang X. Smac, a mitochondrial protein that promotes cytochrome c-dependent caspase activation by eliminating IAP inhibition. Cell. 2000;102(1):33-42.

40. Philchenkov A, Miura K. The IAP protein family, SMAC mimetics and Cancer treatment. Crit Rev Oncog. 2016;21(3-4):185-202.

41. Kerr JF, Wyllie AH, Currie AR. Apoptosis: a basic biological phenomenon with wide-ranging implications in tissue kinetics. Br J Cancer. 1972;26(4):239-57.

42. Fraser C, Ryan J, Sarosiek K. BH3 profiling: a functional assay to measure apoptotic priming and dependencies. Methods Mol Biol. 1877;2019:61-76.

43. Villalobos-Ortiz M, Ryan J, Mashaka TN, Opferman JT, Letai A. BH3 profiling discriminates on-target small molecule $\mathrm{BH} 3$ mimetics from putative mimetics. Cell Death Differ. 2020;27(3):999-1007.

44. Bhola PD, Ahmed E, Guerriero JL, Sicinska E, Su E, Lavrova E, et al. Highthroughput dynamic $\mathrm{BH} 3$ profiling may quickly and accurately predict effective therapies in solid tumors. Sci Signal. 2020;13(636):eaay1451.

45. Cosulich SC, Worrall V, Hedge PJ, Green S, Clarke PR. Regulation of apoptosis by BH3 domains in a cell-free system. Curr Biol. 1997;7(12):913-20.

46. Holinger EP, Chittenden T, Lutz RJ. Bak BH3 peptides antagonize BCl-xL function and induce apoptosis through cytochrome c-independent activation of caspases. J Biol Chem. 1999;274(19):13298-304.

47. Chin JW, Schepartz A. Design and evolution of a miniature BCl-2 binding protein. Angew Chem Int Ed Engl. 2001:40(20):3806-9.

48. Billard C. BH3 mimetics: status of the field and new developments. Mol Cancer Ther. 2013;12(9):1691-700.

49. Baell JB, Huang DC. Prospects for targeting the BCl-2 family of proteins to develop novel cytotoxic drugs. Biochem Pharmacol. 2002;64(5-6):851-63.

50. Lee EF, Czabotar PE, Smith BJ, Deshayes K, Zobel K, Colman PM, et al. Crystal structure of ABT-737 complexed with BCl-xL: implications for selectivity of antagonists of the BCl-2 family. Cell Death Differ. 2007;14(9):1711-3.

51. OltersdorfT, Elmore SW, Shoemaker AR, Armstrong RC, Augeri DJ, Belli $\mathrm{BA}$, et al. An inhibitor of $\mathrm{BCl}-2$ family proteins induces regression of solid tumours. Nature. 2005;435(7042):677-81.

52. Kitada S, Leone M, Sareth S, Zhai D, Reed JC, Pellecchia M. Discovery, characterization, and structure-activity relationships studies of proapoptotic polyphenols targeting B-cell lymphocyte/leukemia-2 proteins. $J$ Med Chem. 2003;46(20):4259-64.

53. Wang JL, Liu D, Zhang ZJ, Shan S, Han X, Srinivasula SM, et al, Structure-based discovery of an organic compound that binds BCl-2 
protein and induces apoptosis of tumor cells. Proc Natl Acad Sci U S A. 2000;97(13):7124-9.

54. Degterev A, Lugovskoy A, Cardone M, Mulley B, Wagner G, Mitchison T, et al. Identification of small-molecule inhibitors of interaction between the BH3 domain and BCl-xL. Nat Cell Biol. 2001;3(2):173-82.

55. Tzung SP, Kim KM, Basanez G, Giedt CD, Simon J, Zimmerberg J, et al. Antimycin a mimics a cell-death-inducing BCl-2 homology domain 3. Nat Cell Biol. 2001;3(2):183-91.

56. Enyedy IJ, Ling Y, Nacro K, Tomita Y, Wu X, Cao Y, et al. Discovery of small-molecule inhibitors of $\mathrm{BCl}-2$ through structure-based computer screening. J Med Chem. 2001;44(25):4313-24.

57. Kutzki O, Park HS, Ernst JT, Orner BP, Yin H, Hamilton AD. Development of a potent $\mathrm{BCl}-\mathrm{x}(\mathrm{L})$ antagonist based on alpha-helix mimicry. J Am Chem Soc. 2002;124(40):11838-9.

58. Park CM, Oie T, Petros AM, Zhang H, Nimmer PM, Henry RF, et al. Design, synthesis, and computational studies of inhibitors of BCl-XL. J Am Chem Soc. 2006;128(50):16206-12.

59. Tse C, Shoemaker AR, Adickes J, Anderson MG, Chen J, Jin S, et al. ABT263: a potent and orally bioavailable BCl-2 family inhibitor. Cancer Res. 2008;68(9):3421-8.

60. Wang G, Nikolovska-Coleska Z, Yang CY, Wang R, Tang G, Guo J, et al. Structure-based design of potent small-molecule inhibitors of antiapoptotic BCl-2 proteins. J Med Chem. 2006;49(21):6139-42.

61. Nguyen M, Marcellus RC, Roulston A, Watson M, Serfass L, Murthy Madiraju SR, et al. Small molecule obatoclax (GX15-070) antagonizes MCL-1 and overcomes MCL-1-mediated resistance to apoptosis. Proc Natl Acad Sci U S A. 2007:104(49):19512-7.

62. Souers AJ, Leverson JD, Boghaert ER, Ackler SL, Catron ND, Chen J, et al. ABT-199, a potent and selective BCL-2 inhibitor, achieves antitumor activity while sparing platelets. Nat Med. 2013;19(2):202-8.

63. Li L, Thomas RM, Suzuki H, De Brabander JK, Wang X, Harran PG. A smal molecule Smac mimic potentiates TRAIL- and TNFalpha-mediated cell death. Science. 2004;305(5689):1471-4

64. Bai L, Chen W, Chen W, Wang X, Tang H, Lin Y. IKKbeta-mediated nuclear factor-kappaB activation attenuates smac mimetic-induced apoptosis in cancer cells. Mol Cancer Ther. 2009;8(6):1636-45.

65. Lu J, Bai L, Sun H, Nikolovska-Coleska Z, McEachern D, Qiu S, et al. SM-164: a novel, bivalent Smac mimetic that induces apoptosis and tumor regression by concurrent removal of the blockade of CIAP-1/2 and XIAP. Cancer Res. 2008;68(22):9384-93.

66. Cai Q, Sun H, Peng Y, Lu J, Nikolovska-Coleska Z, McEachern D, et al. A potent and orally active antagonist (SM-406/AT-406) of multiple inhibitor of apoptosis proteins (IAPs) in clinical development for cancer treatment. J Med Chem. 2011;54(8):2714-26.

67. Weisberg E, Ray A, Barrett R, Nelson E, Christie AL, Porter D, et al. Smac mimetics: implications for enhancement of targeted therapies in leukemia. Leukemia. 2010;24(12):2100-9.

68. Sun H, Nikolovska-Coleska Z, Lu J, Meagher JL, Yang CY, Qiu S, et al. Design, synthesis, and characterization of a potent, nonpeptide, cellpermeable, bivalent Smac mimetic that concurrently targets both the BIR2 and BIR3 domains in XIAP. J Am Chem Soc. 2007;129(49):15279-94.

69. Allensworth JL, Sauer SJ, Lyerly HK, Morse MA, Devi GR. Smac mimetic Birinapant induces apoptosis and enhances TRAIL potency in inflammatory breast cancer cells in an IAP-dependent and TNF-alpha-independent mechanism. Breast Cancer Res Treat. 2013;137(2):359-71.

70. Leverson JD, Zhang H, Chen J, Tahir SK, Phillips DC, Xue J, et al. Potent and selective small-molecule MCL-1 inhibitors demonstrate on-target cancer cell killing activity as single agents and in combination with ABT-263 (navitoclax). Cell Death Dis. 2015;6:e1590.

71. Bruncko M, Wang L, Sheppard GS, Phillips DC, Tahir SK, Xue J, et al. Structure-guided design of a series of MCL-1 inhibitors with high affinity and selectivity. J Med Chem. 2015;58(5):2180-94.

72. Caenepeel S, Brown SP, Belmontes B, Moody G, Keegan KS, Chui D, et al. AMG 176, a selective MCL1 inhibitor, is effective in hematologic Cancer models alone and in combination with established therapies. Cancer Discov. 2018:8(12):1582-97.

73. Tron AE, Belmonte MA, Adam A, Aquila BM, Boise LH, Chiarparin E, et al. Discovery of Mcl-1-specific inhibitor AZD5991 and preclinical activity in multiple myeloma and acute myeloid leukemia. Nat Commun. 2018;9(1):5341.
74. Kotschy A, Szlavik Z, Murray J, Davidson J, Maragno AL, Le ToumelinBraizat $\mathrm{G}$, et al. The MCL1 inhibitor 563845 is tolerable and effective in diverse cancer models. Nature. 2016:538(7626):477-82.

75. Stewart ML, Fire E, Keating AE, Walensky LD. The MCL-1 BH3 helix is an exclusive MCL-1 inhibitor and apoptosis sensitizer. Nat Chem Biol. 2010;6(8):595-601.

76. Ramsey HE, Fischer MA, Lee T, Gorska AE, Arrate MP, Fuller L, et al. A novel MCL1 inhibitor combined with Venetoclax rescues Venetoclax-resistant acute myelogenous leukemia. Cancer Discov. 2018;8(12):1566-81.

77. Lee T, Bian Z, Zhao B, Hogdal LJ, Sensintaffar JL, Goodwin CM, et al. Discovery and biological characterization of potent myeloid cell leukemia-1 inhibitors. FEBS Lett. 2017;591(1):240-51.

78. Folkes AJ, Ahmadi K, Alderton WK, Alix S, Baker SJ, Box G, et al. The identification of 2-(1H-indazol-4-yl)-6-(4-methanesulfonyl-piperazin1-ylmethyl)-4-morpholin-4-yl-t hieno[3,2-d]pyrimidine (GDC-0941) as a potent, selective, orally bioavailable inhibitor of class I PI3 kinase for the treatment of cancer. J Med Chem. 2008;51(18):5522-32.

79. Cleary ML, Smith SD, Sklar J. Cloning and structural analysis of cDNAs for bcl-2 and a hybrid bcl-2/immunoglobulin transcript resulting from the $t(14 ; 18)$ translocation. Cell. 1986;47(1):19-28.

80. Tsujimoto Y, Cossman J, Jaffe E, Croce CM. Involvement of the bcl-2 gene in human follicular lymphoma. Science. 1985;228(4706):1440-3.

81. Vaux DL, Cory S, Adams JM. BCl-2 gene promotes haemopoietic cell survival and cooperates with c-myc to immortalize pre-B cells. Nature. 1988;335(6189):440-2.

82. Cory S, Huang DC, Adams JM. The BCl-2 family: roles in cell survival and oncogenesis. Oncogene. 2003;22(53):8590-607.

83. Correia C, Lee SH, Meng XW, Vincelette ND, Knorr KL, Ding H, et al. Emerging understanding of $\mathrm{BCl}-2$ biology: implications for neoplastic progression and treatment. Biochim Biophys Acta. 2015;1853(7):1658-71.

84. Yip KW, Reed JC. BCl-2 family proteins and cancer. Oncogene. 2008;27(50):6398-406.

85. Tessoulin B, Papin A, Gomez-Bougie P, Bellanger C, Amiot M, PellatDeceunynck C, et al. BCL2-family dysregulation in B-cell malignancies: from gene expression regulation to a targeted therapy biomarker. Front Oncol. 2018;8:645.

86. Tracey L, Perez-Rosado A, Artiga MJ, Camacho Fl, Rodriguez A, Martinez $\mathrm{N}$, et al. Expression of the NF-kappaB targets BCL2 and BIRC5/Survivin characterizes small B-cell and aggressive B-cell lymphomas, respectively. J Pathol. 2005;206(2):123-34.

87. Li Y, Bouchlaka MN, Wolff J, Grindle KM, Lu L, Qian S, et al. FBXO10 deficiency and BTK activation upregulate BCL2 expression in mantle cell lymphoma. Oncogene. 2016;35(48):6223-34.

88. Moreaux J, Klein B, Bataille R, Descamps G, Maiga S, Hose D, et al. A high-risk signature for patients with multiple myeloma established from the molecular classification of human myeloma cell lines. Haematologica. 2011;96(4):574-82.

89. Gong JN, Khong T, Segal D, Yao Y, Riffkin CD, Garnier JM, et al. Hierarchy for targeting prosurvival BCL2 family proteins in multiple myeloma: pivotal role of MCL1. Blood. 2016;128(14):1834-44.

90. Del Gaizo MV, Letai A. BH3 profiling--measuring integrated function of the mitochondrial apoptotic pathway to predict cell fate decisions. Cancer Lett. 2013;332(2):202-5.

91. Wei MC, Zong WX, Cheng EH, Lindsten T, Panoutsakopoulou V, Ross AJ, et al. Proapoptotic BAX and BAK: a requisite gateway to mitochondrial dysfunction and death. Science. 2001;292(5517):727-30.

92. Nechushtan A, Smith CL, Hsu YT, Youle RJ. Conformation of the Bax C-terminus regulates subcellular location and cell death. EMBO J. 1999;18(9):2330-41.

93. Wolter KG, Hsu YT, Smith CL, Nechushtan A, Xi XG, Youle RJ. Movement of Bax from the cytosol to mitochondria during apoptosis. J Cell Biol. 1997:139(5):1281-92.

94. Moldoveanu T, Liu Q, Tocilj A, Watson M, Shore G, Gehring K. The X-ray structure of a BAK homodimer reveals an inhibitory zinc binding site. Mol Cell. 2006;24(5):677-88.

95. Youle RJ, Strasser A. The BCL-2 protein family: opposing activities that mediate cell death. Nat Rev Mol Cell Biol. 2008;9(1):47-59.

96. Dewson G, Kratina T, Sim HW, Puthalakath H, Adams JM, Colman PM, et al. To trigger apoptosis, Bak exposes its BH3 domain 
and homodimerizes via BH3:groove interactions. Mol Cell. 2008;30(3):369-80.

97. George NM, Evans JJ, Luo X. A three-helix homo-oligomerization domain containing $\mathrm{BH} 3$ and $\mathrm{BH} 1$ is responsible for the apoptotic activity of Bax. Genes Dev. 2007;21(15):1937-48.

98. Labi V, Grespi F, Baumgartner F, Villunger A. Targeting the Bcl-2-regulated apoptosis pathway by BH3 mimetics: a breakthrough in anticancer therapy? Cell Death Differ. 2008;15(6):977-87.

99. van Delft MF, Wei AH, Mason KD, Vandenberg CJ, Chen L, Czabotar PE, et al. The BH3 mimetic ABT-737 targets selective $\mathrm{BCl}-2$ proteins and efficiently induces apoptosis via Bak/Bax if Mcl-1 is neutralized. Cancer Cell. 2006;10(5):389-99.

100. Konopleva M, Contractor R, Tsao T, Samudio I, Ruvolo PP, Kitada S, et al. Mechanisms of apoptosis sensitivity and resistance to the $\mathrm{BH} 3$ mimetic ABT-737 in acute myeloid leukemia. Cancer Cell. 2006;10(5):375-88.

101. High LM, Szymanska B, Wilczynska-Kalak U, Barber N, O'Brien R, Khaw $S L$, et al. The BCl-2 homology domain 3 mimetic ABT-737 targets the apoptotic machinery in acute lymphoblastic leukemia resulting in synergistic in vitro and in vivo interactions with established drugs. Mol Pharmacol. 2010;77(3):483-94.

102. Oakes SR, Vaillant F, Lim E, Lee L, Breslin K, Feleppa F, et al. Sensitization of $\mathrm{BCL}$-2-expressing breast tumors to chemotherapy by the $\mathrm{BH} 3$ mimetic ABT-737. Proc Natl Acad Sci U S A. 2012;109(8):2766-71.

103. Song $J H$, Kandasamy $K$, Zemskova M, Lin YW, Kraft AS. The BH3 mimetic ABT-737 induces cancer cell senescence. Cancer Res. 2011;71(2):506-15.

104. Chen S, Dai Y, Harada H, Dent P, Grant S. MCl-1 down-regulation potentiates ABT-737 lethality by cooperatively inducing Bak activation and Bax translocation. Cancer Res. 2007;67(2):782-91.

105. Boiani M, Daniel C, Liu X, Hogarty MD, Marnett LJ. The stress protein BAG3 stabilizes Mcl-1 protein and promotes survival of cancer cells and resistance to antagonist ABT-737. J Biol Chem. 2013:288(10):6980-90.

106. Zhang C, Li YL, Weng X, Li LY, Zhou MX, Zhang DY, et al. Nedaplatin enhanced apoptotic effects of ABT-737 in human cancer cells via Mcl-1 inhibition. Oncol Lett. 2016;12(5):4195-202.

107. Pandit B, Gartel AL. New potential anti-cancer agents synergize with bortezomib and ABT-737 against prostate cancer. Prostate. 2010;70(8):825-33.

108. Allaman-Pillet N, Oberson A, Munier F, Schorderet DF. The BCl-2/BCl$\mathrm{XL}$ inhibitor ABT-737 promotes death of retinoblastoma cancer cells. Ophthalmic Genet. 2013;34(1-2):1-13.

109. Reuland SN, Goldstein NB, Partyka KA, Smith S, Luo Y, Fujita M, et al. ABT-737 synergizes with Bortezomib to kill melanoma cells. Biol Open. 2012;1(2):92-100

110. Yin S, Dong Y, Li J, Fan L, Wang L, Lu J, et al. Methylseleninic acid potentiates multiple types of cancer cells to ABT-737-induced apoptosis by targeting MCl-1 and bad. Apoptosis. 2012;17(4):388-99.

111. Zhang S, Li G, Ma X, Wang Y, Liu G, Feng L, et al. Norcantharidin enhances ABT-737-induced apoptosis in hepatocellular carcinoma cells by transcriptional repression of Mcl-1. Cell Signal. 2012;24(9):1803-9.

112. Bogenberger JM, Delman D, Hansen N, Valdez R, Fauble V, Mesa RA, et al. Ex vivo activity of BCL-2 family inhibitors ABT-199 and ABT-737 combined with 5-azacytidine in myeloid malignancies. Leuk Lymphoma. 2015;56(1):226-9.

113. Li JY, Li YY, Jin W, Yang Q, Shao ZM, Tian XS. ABT-737 reverses the acquired radioresistance of breast cancer cells by targeting $\mathrm{BCl}-2$ and Bcl-xL. J Exp Clin Cancer Res. 2012;31:102.

114. Chen ZJ, Zhang B, Pan SH, Zhao HM, Zhang Y. Feng WH et al: [BCl-2 inhibitor ABT-737 enhances the cisplatin-induced apoptosis in breast cancer T47D cells]. Zhonghua Zhong Liu Za Zhi. 2011;33(12):891-5.

115. Choi JE, Woo SM, Min KJ, Kang SH, Lee SJ, Kwon TK. Combined treatment with ABT-737 and VX-680 induces apoptosis in BCl-2- and c-FLIPoverexpressing breast carcinoma cells. Oncol Rep. 2015;33(3):1395-401.

116. Hwang E, Hwang SH, Kim J, Park JH, Oh S, Kim YA, et al. ABT-737 ameliorates docetaxel resistance in triple negative breast cancer cell line. Ann Surg Treat Res. 2018;95(5):240-8.

117. Raats DA, de Bruijn MT, Steller EJ, Emmink BL, Borel-Rinkes $I H$, Kranenburg O. Synergistic killing of colorectal cancer cells by oxaliplatin and ABT-737. Cell Oncol (Dordr). 2011;34(4):307-13.

118. Huang S, Sinicrope FA. Celecoxib-induced apoptosis is enhanced by ABT-737 and by inhibition of autophagy in human colorectal cancer cells. Autophagy. 2010;6(2):256-69.
119. Premkumar DR, Jane EP, DiDomenico JD, Vukmer NA, Agostino NR, Pollack IF. ABT-737 synergizes with bortezomib to induce apoptosis, mediated by bid cleavage, Bax activation, and mitochondrial dysfunction in an Akt-dependent context in malignant human glioma cell lines. J Pharmacol Exp Ther. 2012;341(3):859-72.

120. Li R, Zang Y, Li C, Patel NS, Grandis JR, Johnson DE. ABT-737 synergizes with chemotherapy to kill head and neck squamous cell carcinoma cells via a Noxa-mediated pathway. Mol Pharmacol. 2009;75(5):1231-9.

121. Shen J, Xu L, Zhao Q. Perifosine and ABT-737 synergistically inhibit lung cancer cells in vitro and in vivo. Biochem Biophys Res Commun. 2016;473(4):1170-6.

122. Opydo-Chanek M, Rak A, Cierniak A, Mazur L. Combination of ABT-737 and resveratrol enhances DNA damage and apoptosis in human T-cell acute lymphoblastic leukemia MOLT-4 cells. Toxicol in Vitro. 2017:42:38-46.

123. Opydo-Chanek M, Mazur L. Comparison of in vitro antileukemic activity of obatoclax and ABT-737. Tumour Biol. 2016;37(8):10839-49.

124. Ugarenko M, Nudelman A, Rephaeli A, Kimura K, Phillips DR, Cutts SM ABT-737 overcomes BCl-2 mediated resistance to doxorubicin-DNA adducts. Biochem Pharmacol. 2010;79(3):339-49.

125. Zheng R, You Z, Jia J, Lin S, Han S, Liu A, et al. Curcumin enhances the antitumor effect of ABT-737 via activation of the ROS-ASK1-JNK pathway in hepatocellular carcinoma cells. Mol Med Rep. 2016;13(2):1570-6.

126. Kim EY, Jung JY, Kim A, Chang YS, Kim SK. ABT-737 synergizes with cisplatin bypassing aberration of apoptotic pathway in non-small cell lung Cancer. Neoplasia. 2017;19(4):354-63.

127. Kim LH, Shin JA, Jang B, Yang $I H$, Won DH, Jeong JH, et al. Sorafenib potentiates ABT-737-induced apoptosis in human oral cancer cells. Arch Oral Biol. 2017;73:1-6.

128. Zhang F, Yu X, Liu X, Zhou T, Nie T, Cheng M, et al. ABT-737 potentiates cisplatin-induced apoptosis in human osteosarcoma cells via the mitochondrial apoptotic pathway. Oncol Rep. 2017;38(4):2301-8.

129. Li YL, Sun J, Hu X, Pan YN, Yan W, Li QY, et al. Epothilone B induces apoptosis and enhances apoptotic effects of ABT-737 on human cancer cells via PI3K/AKT/mTOR pathway. J Cancer Res Clin Oncol. 2016;142(11):2281-9.

130. Florent $R$, Weiswald LB, Lambert B, Brotin E, Abeilard E, Louis MH, et al. Bim, Puma and Noxa upregulation by Naftopidil sensitizes ovarian cancer to the BH3-mimetic ABT-737 and the MEK inhibitor Trametinib. Cell Death Dis. 2020;11(5):380.

131. De Wolf E, De Wolf C, Richardson A. ABT-737 and pictilisib synergistically enhance pitavastatin-induced apoptosis in ovarian cancer cells. Oncol Lett. 2018;15(2):1979-84.

132. Witham J, Valenti MR, De-Haven-Brandon AK, Vidot S, Eccles SA, Kaye $\mathrm{SB}$, et al. The BCl-2/BCl-XL family inhibitor ABT-737 sensitizes ovarian cancer cells to carboplatin. Clin Cancer Res. 2007;13(23):7191-8.

133. Jain HV, Meyer-Hermann M. The molecular basis of synergism between carboplatin and ABT-737 therapy targeting ovarian carcinomas. Cancer Res. 2011;71(3):705-15.

134. Song JH, Kandasamy K, Kraft AS. ABT-737 induces expression of the death receptor 5 and sensitizes human cancer cells to TRAlL-induced apoptosis. J Biol Chem. 2008;283(36):25003-13.

135. Broecker-Preuss M, Becher-Boveleth N, Muller S, Mann K. The BH3 mimetic drug ABT-737 induces apoptosis and acts synergistically with chemotherapeutic drugs in thyroid carcinoma cells. Cancer Cell Int. 2016;16:27.

136. Shen HP, Wu WJ, Ko JL, Wu TF, Yang SF, Wu CH, et al. Effects of ABT-737 combined with irradiation treatment on uterine cervical cancer cells. Oncol Lett. 2019;18(4):4328-36.

137. Bhat UG, Pandit B, Gartel AL. ARC synergizes with ABT-737 to induce apoptosis in human cancer cells. Mol Cancer Ther. 2010;9(6):1688-96.

138. Vogler M, Furdas SD, Jung M, Kuwana T, Dyer MJ, Cohen GM. Diminished sensitivity of chronic lymphocytic leukemia cells to ABT-737 and ABT-263 due to albumin binding in blood. Clin Cancer Res. 2010;16(16):4217-25.

139. Lian BSX, Yek AEH, Shuvas H, Abdul Rahman SF, Muniandy K, MohanaKumaran N. Synergistic anti-proliferative effects of combination of ABT-263 and MCL-1 selective inhibitor A-1210477 on cervical cancer cell lines. BMC Res Notes. 2018;11(1):197.

140. Ackler S, Mitten MJ, Foster K, Oleksijew A, Refici M, Tahir SK, et al. The $\mathrm{BCl}-2$ inhibitor ABT-263 enhances the response of multiple 
chemotherapeutic regimens in hematologic tumors in vivo. Cancer Chemother Pharmacol. 2010;66(5):869-80.

141. Kivioja JL, Thanasopoulou A, Kumar A, Kontro M, Yadav B, Majumder MM, et al. Dasatinib and navitoclax act synergistically to target NUP98-NSD1(+)/FLT3-ITD(+) acute myeloid leukemia. Leukemia. 2019;33(6):1360-72.

142. Polier G, Giaisi M, Kohler R, Muller WW, Lutz C, Buss EC, et al. Targeting CDK9 by wogonin and related natural flavones potentiates the anti-cancer efficacy of the Bcl-2 family inhibitor ABT-263. Int J Cancer. 2015;136(3):688-98

143. Shao H, Jing K, Mahmoud E, Huang H, Fang X, Yu C. Apigenin sensitizes colon cancer cells to antitumor activity of ABT-263. Mol Cancer Ther. 2013;12(12):2640-50.

144. Li J, Chen Y, Wan J, Liu X, Yu C, Li W. ABT-263 enhances sorafenibinduced apoptosis associated with Akt activity and the expression of Bax and p21 ((CIP1/WAF1)) in human cancer cells. Br J Pharmacol. 2014;171(13):3182-95

145. Sale MJ, Cook SJ. The BH3 mimetic ABT-263 synergizes with the MEK1/2 inhibitor selumetinib/AZD6244 to promote BIM-dependent tumour cell death and inhibit acquired resistance. Biochem J. 2013:450(2):285-94.

146. Chen Q, Song S, Wei S, Liu B, Honjo S, Scott A, et al. ABT-263 induces apoptosis and synergizes with chemotherapy by targeting stemness pathways in esophageal cancer. Oncotarget. 2015;6(28):25883-96.

147. Lin QH, Que FC, Gu CP, Zhong DS, Zhou D, Kong Y, et al. ABT263 induces G1/G0-phase arrest, apoptosis and autophagy in human esophageal cancer cells in vitro. Acta Pharmacol Sin. 2017:38(12):1632-41.

148. Britt EL, Raman S, Leek K, Sheehy CH, Kim SW, Harada H. Combination of fenretinide and ABT-263 induces apoptosis through NOXA for head and neck squamous cell carcinoma treatment. PLoS One. 2019;14(7):e0219398.

149. Wang G, Zhan Y, Wang H, Li W. ABT-263 sensitizes TRAlL-resistant hepatocarcinoma cells by downregulating the $\mathrm{Bcl}-2$ family of anti-apoptotic protein. Cancer Chemother Pharmacol. 2012;69(3):799-805.

150. Sakuma Y, Tsunezumi J, Nakamura Y, Yoshihara M, Matsukuma S, Koizume S, et al. ABT-263, a BCl-2 inhibitor, enhances the susceptibility of lung adenocarcinoma cells treated with Src inhibitors to anoikis. Oncol Rep. 2011:25(3):661-7.

151. Matsumoto M, Nakajima W, Seike M, Gemma A, Tanaka N. Cisplatininduced apoptosis in non-small-cell lung cancer cells is dependent on Bax- and Bak-induction pathway and synergistically activated by BH3mimetic ABT-263 in p53 wild-type and mutant cells. Biochem Biophys Res Commun. 2016;473(2):490-6.

152. Nakajima W, Sharma K, Hicks MA, Le N, Brown R, Krystal GW, et al. Combination with vorinostat overcomes ABT-263 (navitoclax) resistance of small cell lung cancer. Cancer Biol Ther. 2016;17(1):27-35.

153. Ackler S, Xiao Y, Mitten MJ, Foster K, Oleksijew A, Refici M, et al. ABT-263 and rapamycin act cooperatively to kill lymphoma cells in vitro and in vivo. Mol Cancer Ther. 2008:7(10):3265-74.

154. Wang X, Gu Z, Li G, Zhang S, Cao Z, Yang Z, et al. Norcantharidin enhances ABT-263-mediated anticancer activity in neuroblastoma cells by upregulation of Noxa. Oncol Rep. 2014;32(2):716-22.

155. Wang C, Huang SB, Yang MC, Lin YT, Chu IH, Shen YN, et al. Combining paclitaxel with ABT-263 has a synergistic effect on paclitaxel resistant prostate cancer cells. PLoS One. 2015;10(3):e0120913.

156. Wei X, Zhou P, Lin X, Lin Y, Wu S, Diao P, et al. MLN2238 synergizes BH3 mimetic ABT-263 in castration-resistant prostate cancer cells by induction of NOXA. Tumour Biol. 2014;35(10):10213-21.

157. Wong M, Tan N, Zha J, Peale FV, Yue P, Fairbrother WJ, et al. Navitoclax (ABT-263) reduces BCl-x(L)-mediated chemoresistance in ovarian cancer models. Mol Cancer Ther. 2012;11(4):1026-35.

158. Li X, Li B, Ni Z, Zhou P, Wang B, He J, et al. Metformin synergizes with $\mathrm{BCL}-\mathrm{XL} / \mathrm{BCL}-2$ inhibitor $\mathrm{ABT}-263$ to induce apoptosis specifically in p53-defective Cancer cells. Mol Cancer Ther. 2017;16(9):1806-18.

159. Wang B, Ni Z, Dai X, Qin L, Li X, Xu L, et al. The BCl-2/XL inhibitor ABT-263 increases the stability of Mcl-1 mRNA and protein in hepatocellular carcinoma cells. Mol Cancer. 2014;13:98.

160. Lee EY, Gong EY, Shin JS, Moon JH, Shim HJ, Kim SM, et al. Human breast cancer cells display different sensitivities to ABT-263 based on the level of survivin. Toxicol in Vitro. 2018;46:229-36.
161. Lee YC, Wang LJ, Huang CH, Chiou JT, Shi YJ, Chang LS. Inhibition of EGFR pathway promotes the cytotoxicity of ABT-263 in human leukemia K562 cells by blocking MCL1 upregulation. Biochem Pharmacol. 2020;178:114047.

162. Xu J, Zhu GY, Cao D, Pan H, Li YW. Gossypol overcomes EGFR-TKIs resistance in non-small cell lung cancer cells by targeting YAP/TAZ and EGFR(L858R/T790M). Biomed Pharmacother. 2019:115:108860.

163. Wang Y, Lai H, Fan X, Luo L, Duan F, Jiang Z, et al. Gossypol inhibits non-small cell lung Cancer cells proliferation by targeting EGFR(L858R/ T790M). Front Pharmacol. 2018;9:728.

164. Huang YW, Wang LS, Chang HL, Ye W, Dowd MK, Wan PJ, et al. Molecular mechanisms of (-)-gossypol-induced apoptosis in human prostate cancer cells. Anticancer Res. 2006;26(3A):1925-33.

165. Zhang M, Liu H, Tian Z, Griffith BN, Ji M, Li QQ. Gossypol induces apoptosis in human PC-3 prostate cancer cells by modulating caspasedependent and caspase-independent cell death pathways. Life Sci. 2007;80(8):767-74.

166. Wang J, Jin L, Li X, Deng H, Chen Y, Lian Q, et al. Gossypol induces apoptosis in ovarian cancer cells through oxidative stress. Mol BioSyst. 2013:9(6):1489-97.

167. Macoska JA, Adsule S, Tantivejkul K, Wang S, Pienta KJ, Lee CT. (-)gossypol promotes the apoptosis of bladder cancer cells in vitro. Pharmacol Res. 2008;58(5-6):323-31.

168. Gilbert NE, O'Reilly JE, Chang CJ, Lin YC, Brueggemeier RW. Antiproliferative activity of gossypol and gossypolone on human breast cancer cells. Life Sci. 1995;57(1):61-7.

169. Ye W, Chang HL, Wang LS, Huang YW, Shu S, Sugimoto Y, et al. Induction of apoptosis by (-)-gossypol-enriched cottonseed oil in human breast cancer cells. Int J Mol Med. 2010;26(1):113-9.

170. Meng Y, Tang W, Dai Y, Wu X, Liu M, Ji Q, et al. Natural BH3 mimetic (-)-gossypol chemosensitizes human prostate cancer via Bcl-xL inhibition accompanied by increase of Puma and Noxa. Mol Cancer Ther. 2008;7(7):2192-202.

171. Volate SR, Kawasaki BT, Hurt EM, Milner JA, Kim YS, White J, et al. Gossypol induces apoptosis by activating p53 in prostate cancer cells and prostate tumor-initiating cells. Mol Cancer Ther. 2010;9(2):461-70.

172. Zhang G, Wang Z, Chen W, Cao Y, Wu J, Qiang G, et al. Dual effects of gossypol on human hepatocellular carcinoma via endoplasmic reticulum stress and autophagy. Int J Biochem Cell Biol. 2019;113:48-57.

173. Xu R, Tian E, Tang H, Liu C, Wang Q. Proteomic analysis of gossypol induces necrosis in multiple myeloma cells. Biomed Res Int. 2014:2014:839232.

174. Lian J, Ni Z, Dai X, Su C, Smith AR, Xu L, et al. Sorafenib sensitizes (-)-gossypol-induced growth suppression in androgen-independent prostate cancer cells via Mcl-1 inhibition and Bak activation. Mol Cancer Ther. 2012:11(2):416-26.

175. Jang GH, Lee M. BH3-mimetic gossypol-induced autophagic cell death in mutant BRAF melanoma cells with high expression of p21Cip(1). Life Sci. 2014;102(1):41-8

176. Huang YW, Wang LS, Dowd MK, Wan PJ. Lin YC: (-)-gossypol reduces invasiveness in metastatic prostate cancer cells. Anticancer Res. 2009;29(6):2179-88

177. Meyer N, Zielke S, Michaelis JB, Linder B, Warnsmann V, Rakel S, et al. AT 101 induces early mitochondrial dysfunction and HMOX1 (heme oxygenase 1) to trigger mitophagic cell death in glioma cells. Autophagy. 2018;14(10):1693-709.

178. Etxebarria A, Landeta O, Antonsson B, Basanez G. Regulation of antiapoptotic MCL-1 function by gossypol: mechanistic insights from in vitro reconstituted systems. Biochem Pharmacol. 2008;76(11):1563-76.

179. Mallick DJ, Eastman A. AT101 [(-)-Gossypol] Selectively Inhibits MCL1 and Sensitizes Carcinoma to BH3 Mimetics by Inducing and Stabilizing NOXA. Cancers (Basel). 2020:12(8):2298.

180. Kim HY, Lee BI, Jeon JH, Kim DK, Kang SG, Shim JK, et al. Gossypol Suppresses Growth of Temozolomide-Resistant Glioblastoma Tumor Spheres. Biomolecules. 2019;9(10):595.

181. Meng Y, Li Y, Li J, Li H, Fu J. Liu Y et al: (-)gossypol and its combination with imatinib induce apoptosis in human chronic myeloid leukemic cells. Leuk Lymphoma. 2007:48(11):2204-12.

182. Yang D, Qu J, Qu X, Cao Y, Xu L, Hou K, et al. Gossypol sensitizes the antitumor activity of 5-FU through down-regulation of thymidylate 
synthase in human colon carcinoma cells. Cancer Chemother Pharmacol. 2015;76(3):575-86

183. Wong FY, Liem N, Xie C, Yan FL, Wong WC, Wang L, et al. Combination therapy with gossypol reveals synergism against gemcitabine resistance in cancer cells with high BCL-2 expression. PLoS One. 2012;7(12):e50786.

184. Atmaca H, Gorumlu G, Karaca B, Degirmenci M, Tunali D, Cirak Y, et al. Combined gossypol and zoledronic acid treatment results in synergistic induction of cell death and regulates angiogenic molecules in ovarian cancer cells. Eur Cytokine Netw. 2009;20(3):121-30.

185. Yeow WS, Baras A, Chua A, Nguyen DM, Sehgal SS, Schrump DS, et al. Gossypol, a phytochemical with BH3-mimetic property, sensitizes cultured thoracic cancer cells to Apo2 ligand/tumor necrosis factor-related apoptosis-inducing ligand. J Thorac Cardiovasc Surg. 2006;132(6):1356-62.

186. Bulut G, Atmaca H, Karaca B. Trastuzumab in combination with AT-101 induces cytotoxicity and apoptosis in Her2 positive breast cancer cells. Future Oncol. 2020;16(3):4485-95.

187. Mohammad RM, Wang S, Banerjee S, Wu X, Chen J, Sarkar FH. Nonpeptidic small-molecule inhibitor of $\mathrm{BCl}-2$ and $\mathrm{BCl}-\mathrm{XL}_{1}(-)$-gossypol, enhances biological effect of genistein against BXPC-3 human pancreatic cancer cell line. Pancreas. 2005;31(4):317-24.

188. Xu L, Yang D, Wang S, Tang W, Liu M. Davis M et al: (-)-gossypol enhances response to radiation therapy and results in tumor regression of human prostate cancer. Mol Cancer Ther. 2005;4(2):197-205.

189. McGregor N, Patel L, Craig M, Weidner S, Wang S, Pienta KJ. AT-101 (R-(-)-gossypol acetic acid) enhances the effectiveness of androgen deprivation therapy in the VCaP prostate cancer model. J Cell Biochem. 2010;110(5):1187-94.

190. Konopleva M, Watt J, Contractor R, Tsao T, Harris D, Estrov Z, et al. Mechanisms of antileukemic activity of the novel $\mathrm{BCl}-2$ homology domain-3 mimetic GX15-070 (obatoclax). Cancer Res. 2008;68(9):3413-20.

191. Goard CA, Schimmer AD. An evidence-based review of obatoclax mesylate in the treatment of hematological malignancies. Core Evid. 2013:8:15-26.

192. Vogler M. Targeting BCL2-proteins for the treatment of solid Tumours. Adv Med. 2014;2014:943648.

193. Li J, Viallet J, Haura EB. A small molecule pan-Bcl-2 family inhibitor, GX15-070, induces apoptosis and enhances cisplatin-induced apoptosis in non-small cell lung cancer cells. Cancer Chemother Pharmacol. 2008;61(3):525-34.

194. Champa D, Russo MA, Liao XH, Refetoff S, Ghossein RA, Di Cristofano A. Obatoclax overcomes resistance to cell death in aggressive thyroid carcinomas by countering $\mathrm{Bcl} 2 \mathrm{a} 1$ and $\mathrm{Mcl} 1$ overexpression. Endocr Relat Cancer. 2014;21(5):755-67.

195. Rahmani M, Aust MM, Attkisson E, Williams DC Jr, Ferreira-Gonzalez A, Grant S. Inhibition of Bcl-2 antiapoptotic members by obatoclax potently enhances sorafenib-induced apoptosis in human myeloid leukemia cells through a Bim-dependent process. Blood. 2012;119(25):6089-98

196. Jimenez-Guerrero R, Gasca J, Flores ML, Perez-Valderrama B, Tejera-Parrado C, Medina R, et al. Obatoclax and paclitaxel synergistically induce apoptosis and overcome paclitaxel resistance in urothelial cancer cells. Cancers (Basel). 2018;10(12):490.

197. Steele TM, Talbott GC, Sam A, Tepper CG, Ghosh PM, Vinall RL. Obatoclax, a BH3 Mimetic, Enhances Cisplatin-Induced Apoptosis and Decreases the Clonogenicity of Muscle Invasive Bladder Cancer Cells via Mechanisms That Involve the Inhibition of Pro-Survival Molecules as Well as Cell Cycle Regulators. Int J Mol Sci. 2019;20(6):1285-300.

198. Mott JL, Bronk SF, Mesa RA, Kaufmann SH, Gores GJ. BH3-only protein mimetic obatoclax sensitizes cholangiocarcinoma cells to Apo2L/TRAILinduced apoptosis. Mol Cancer Ther. 2008;7(8):2339-47.

199. Gariboldi MB, Taiana E, Bonzi MC, Craparotta I, Giovannardi S, Mancini $\mathrm{M}$, et al. The BH3-mimetic obatoclax reduces HIF-1alpha levels and HIF-1 transcriptional activity and sensitizes hypoxic colon adenocarcinoma cells to 5-fluorouracil. Cancer Lett. 2015;364(2):156-64.

200. Zhao XY, Lin QH, Que FC, Gu CP, Yu L. Liu SW: [synergistic anti-tumor effect of obatoclax and MG-132 in esophageal cancer cell line CaES-17]. Nan Fang Yi Ke Da Xue Xue Bao. 2016;36(4):506-13.

201. Berghauser Pont LM, Spoor JK, Venkatesan S, Swagemakers S, Kloezeman JJ, Dirven CM, et al. The BCl-2 inhibitor Obatoclax overcomes resistance to histone deacetylase inhibitors SAHA and LBH589 as radiosensitizers in patient-derived glioblastoma stem-like cells. Genes Cancer. 2014:5(11-12):445-59.

202. Yin YP, Shi WH, Deng K, Liu XL, Li H, Lv XT, et al. Combinations of proteasome inhibitors with obatoclax are effective for small cell lung cancer. Acta Pharmacol Sin. 2021;42(8):1298-310.

203. Crawford N, Chacko AD, Savage KI, McCoy F, Redmond K, Longley $\mathrm{DB}$, et al. Platinum resistant cancer cells conserve sensitivity to $\mathrm{BH} 3$ domains and obatoclax induced mitochondrial apoptosis. Apoptosis. 2011;16(3):311-20.

204. Cournoyer S, Addioui A, Belounis A, Beaunoyer M, Nyalendo C, Le Gall R, et al. GX15-070 (Obatoclax), a Bcl-2 family proteins inhibitor engenders apoptosis and pro-survival autophagy and increases Chemosensitivity in neuroblastoma. BMC Cancer. 2019:19(1):1018.

205. Hou XF, Li S, Wu C, Li K, Xu SN, Wang JF. Effects of obatoclax combined with gemcitabine on the biological activity of pancreatic cancer cells under hypoxic conditions. Mol Med Rep. 2018;18(1):495-501.

206. Huang S, Okumura K, Sinicrope FA. BH3 mimetic obatoclax enhances TRAIL-mediated apoptosis in human pancreatic cancer cells. Clin Cancer Res. 2009;15(1):150-9.

207. Wang G, Chen S, Edwards H, Cui X, Cui L, Ge Y. Combination of chloroquine and GX15-070 (obatoclax) results in synergistic cytotoxicity against pancreatic cancer cells. Oncol Rep. 2014;32(6):2789-94.

208. Chen S, Wang G, Niu X, Zhao J, Tan W, Wang H, et al. Combination of AZD2281 (Olaparib) and GX15-070 (Obatoclax) results in synergistic antitumor activities in preclinical models of pancreatic cancer. Cancer Lett. 2014;348(1-2):20-8.

209. Wei WJ, Sun ZK, Shen CT, Song HJ, Zhang XY, Qiu ZL, et al. Obatoclax and LY3009120 efficiently overcome Vemurafenib resistance in differentiated thyroid cancer. Theranostics. 2017;7(4):987-1001.

210. Hauck P, Chao BH, Litz J, Krystal GW. Alterations in the Noxa/Mcl-1 axis determine sensitivity of small cell lung cancer to the $\mathrm{BH} 3$ mimetic ABT737. Mol Cancer Ther. 2009;8(4):883-92.

211. Nakajima W, Hicks MA, Tanaka N, Krystal GW, Harada H. Noxa determines localization and stability of MCL-1 and consequently ABT-737 sensitivity in small cell lung cancer. Cell Death Dis. 2014;5:e1052.

212. Sakakibara-Konishi J, Oizumi S, Kikuchi J, Kikuchi E, Mizugaki H, Kinoshita I, et al. Expression of Bim, Noxa, and Puma in non-small cell lung cancer. BMC Cancer. 2012;12:286

213. Yan J, Zhong N, Liu G, Chen K, Liu X, Su L, et al. Usp9x- and Noxamediated Mcl-1 downregulation contributes to pemetrexed-induced apoptosis in human non-small-cell lung cancer cells. Cell Death Dis. 2014;5:e1316.

214. Smit LA, Hallaert DY, Spijker R, de Goeij B, Jaspers A, Kater AP, et al. Differential Noxa/Mcl-1 balance in peripheral versus lymph node chronic lymphocytic leukemia cells correlates with survival capacity. Blood. 2007:109(4):1660-8.

215. Zhang $L N, L i J Y, X u$ W. A review of the role of Puma, Noxa and Bim in the tumorigenesis, therapy and drug resistance of chronic lymphocytic leukemia. Cancer Gene Ther. 2013;20(1):1-7.

216. Marshall AD, Picchione F, Geltink RI, Grosveld GC. PAX3-FOXO1 induces up-regulation of Noxa sensitizing alveolar rhabdomyosarcoma cells to apoptosis. Neoplasia. 2013;15(7):738-48.

217. Ramirez-Peinado S, Alcazar-Limones F, Lagares-Tena L, El Mjiyad N, Caro-Maldonado A, Tirado OM, et al. 2-deoxyglucose induces Noxadependent apoptosis in alveolar rhabdomyosarcoma. Cancer Res. 2011;71(21):6796-806.

218. Diallo JS, Aldejmah A, Mouhim AF, Peant B, Fahmy MA, Koumakpayi IH, et al. NOXA and PUMA expression add to clinical markers in predicting biochemical recurrence of prostate cancer patients in a survival tree model. Clin Cancer Res. 2007;13(23):7044-52.

219. Lin C, Zhao XY, Li L, Liu HY, Cao K, Wan Y, et al. NOXA-induced alterations in the Bax/Smac axis enhance sensitivity of ovarian cancer cells to cisplatin. PLoS One. 2012;7(5):e36722.

220. Conti A, Majorini MT, Elliott R, Ashworth A, Lord CJ, Cancelliere C, et al. Oncogenic KRAS sensitizes premalignant, but not malignant cells, to Noxa-dependent apoptosis through the activation of the MEK/ERK pathway. Oncotarget. 2015;6(13):10994-1008.

221. Jansson AK, Emterling AM, Arbman G, Sun XF. Noxa in colorectal cancer: a study on DNA, mRNA and protein expression. Oncogene. 2003;22(30):4675-8 
222. Mukherjee N, Lu Y, Almeida A, Lambert K, Shiau CW, Su JC, et al. Use of a MCL-1 inhibitor alone to de-bulk melanoma and in combination to kill melanoma initiating cells. Oncotarget. 2017;8(29):46801-17.

223. Kelly KR, Espitia CM, Mahalingam D, Oyajobi BO, Coffey M, Giles FJ, et al. Reovirus therapy stimulates endoplasmic reticular stress, NOXA induction, and augments bortezomib-mediated apoptosis in multiple myeloma. Oncogene. 2012;31(25):3023-38.

224. Chen L, Willis SN, Wei A, Smith BJ, Fletcher Jl, Hinds MG, et al. Differential targeting of prosurvival $\mathrm{BCl}-2$ proteins by their $\mathrm{BH}$-only ligands allows complementary apoptotic function. Mol Cell. 2005;17(3):393-403.

225. Chen LS, Balakrishnan K, Gandhi V. Inflammation and survival pathways: chronic lymphocytic leukemia as a model system. Biochem Pharmacol. 2010;80(12):1936-45.

226. Erlacher M, Labi V, Manzl C, Bock G, Tzankov A, Hacker G, et al. Puma cooperates with Bim, the rate-limiting $\mathrm{BH}$-only protein in cell death during lymphocyte development, in apoptosis induction. J Exp Med. 2006;203(13):2939-51

227. Edwards AL, Gavathiotis E, LaBelle JL, Braun CR, Opoku-Nsiah KA, Bird $\mathrm{GH}$, et al. Multimodal interaction with $\mathrm{BCL}-2$ family proteins underlies the proapoptotic activity of PUMA BH3. Chem Biol. 2013;20(7):888-902.

228. Letai A, Bassik MC, Walensky LD, Sorcinelli MD, Weiler S, Korsmeyer SJ. Distinct BH3 domains either sensitize or activate mitochondrial apoptosis, serving as prototype cancer therapeutics. Cancer Cell. 2002;2(3):183-92.

229. Day CL, Smits C, Fan FC, Lee EF, Fairlie WD, Hinds MG. Structure of the $\mathrm{BH} 3$ domains from the $\mathrm{p} 53$-inducible $\mathrm{BH} 3$-only proteins Noxa and Puma in complex with Mcl-1. J Mol Biol. 2008;380(5):958-71.

230. Fulda S, Vucic D. Targeting IAP proteins for therapeutic intervention in cancer. Nat Rev Drug Discov. 2012;11(2):109-24.

231. Condon SM, Mitsuuchi Y, Deng Y, LaPorte MG, Rippin SR, Haimowitz $T$, et al. Birinapant, a smac-mimetic with improved tolerability for the treatment of solid tumors and hematological malignancies. J Med Chem. 2014;57(9):3666-77.

232. Zender L, Spector MS, Xue W, Flemming P, Cordon-Cardo C, Silke J, et al. Identification and validation of oncogenes in liver cancer using an integrative oncogenomic approach. Cell. 2006;125(7):1253-67.

233. de Almagro MC, Vucic D. The inhibitor of apoptosis (IAP) proteins are critical regulators of signaling pathways and targets for anti-cancer therapy. Exp Oncol. 2012;34(3):200-11.

234. Obexer P, Ausserlechner MJ. X-linked inhibitor of apoptosis protein - a critical death resistance regulator and therapeutic target for personalized cancer therapy. Front Oncol. 2014:4:197.

235. Varfolomeev E, Blankenship JW, Wayson SM, Fedorova AV, Kayagaki N, Garg P, et al. IAP antagonists induce autoubiquitination of C-IAPS, NF-kappaB activation, and TNFalpha-dependent apoptosis. Cell. 2007:131(4):669-81.

236. Bertrand MJ, Milutinovic S, Dickson KM, Ho WC, Boudreault A, Durkin J, et al. CIAP1 and CIAP2 facilitate cancer cell survival by functioning as E3 ligases that promote RIP1 ubiquitination. Mol Cell. 2008;30(6):689-700.

237. Mahoney DJ, Cheung HH, Mrad RL, Plenchette S, Simard C, Enwere E, et al. Both CIAP1 and CIAP2 regulate TNFalpha-mediated NF-kappaB activation. Proc Natl Acad Sci U S A. 2008;105(33):11778-83.

238. Vince JE, Wong WW, Khan N, Feltham R, Chau D, Ahmed AU, et al. IAP antagonists target CIAP1 to induce TNFalpha-dependent apoptosis. Cell. 2007;131(4):682-93.

239. Fulda S, Wick W, Weller M, Debatin KM. Smac agonists sensitize for Apo2L/TRAIL- or anticancer drug-induced apoptosis and induce regression of malignant glioma in vivo. Nat Med. 2002;8(8):808-15.

240. Carter BZ, Milella M, Tsao T, McQueen T, Schober WD, Hu W, et al. Regulation and targeting of antiapoptotic XIAP in acute myeloid leukemia. Leukemia. 2003;17(11):2081-9.

241. Arnt CR, Chiorean MV, Heldebrant MP, Gores GJ, Kaufmann SH. Synthetic Smac/DIABLO peptides enhance the effects of chemotherapeutic agents by binding XIAP and CIAP1 in situ. J Biol Chem. 2002;277(46):44236-43.

242. Silke J, Hawkins CJ, Ekert PG, Chew J, Day CL, Pakusch M, et al. The antiapoptotic activity of XIAP is retained upon mutation of both the caspase 3- and caspase 9-interacting sites. J Cell Biol. 2002;157(1):115-24.

243. Bratton SB, Walker G, Srinivasula SM, Sun XM, Butterworth M, Alnemri $E S$, et al. Recruitment, activation and retention of caspases- 9 and
-3 by Apaf-1 apoptosome and associated XIAP complexes. EMBO J. 2001;20(5):998-1009.

244. Wu G, Chai J, Suber TL, Wu JW, Du C, Wang X, et al. Structural basis of IAP recognition by Smac/DIABLO. Nature. 2000;408(6815):1008-12.

245. Ekert PG, Silke J, Hawkins CJ, Verhagen AM, Vaux DL. DIABLO promotes apoptosis by removing MIHA/XIAP from processed caspase 9. J Cell Biol. 2001;152(3):483-90.

246. Eckhardt I, Roesler S, Fulda S. Identification of DR5 as a critical, NFkappaB-regulated mediator of Smac-induced apoptosis. Cell Death Dis. 2013;4:e936.

247. Fulda S. Smac mimetics as IAP antagonists. Semin Cell Dev Biol. 2015:39:132-8

248. Wagner L, Marschall V, Karl S, Cristofanon S, Zobel K, Deshayes K, et al. Smac mimetic sensitizes glioblastoma cells to Temozolomide-induced apoptosis in a RIP1- and NF-kappaB-dependent manner. Oncogene. 2013;32(8):988-97.

249. Chromik J, Safferthal C, Serve H, Fulda S. Smac mimetic primes apoptosis-resistant acute myeloid leukaemia cells for cytarabine-induced cell death by triggering necroptosis. Cancer Lett. 2014;344(1):101-9.

250. Belz K, Schoeneberger H, Wehner S, Weigert A, Bonig H, Klingebiel T, et al. Smac mimetic and glucocorticoids synergize to induce apoptosis in childhood ALL by promoting ripoptosome assembly. Blood. 2014;124(2):240-50.

251. Probst BL, Liu L, Ramesh V, Li L, Sun H, Minna JD, et al. Smac mimetics increase cancer cell response to chemotherapeutics in a TNF-alphadependent manner. Cell Death Differ. 2010;17(10):1645-54.

252. Wang L, Du F, Wang X. TNF-alpha induces two distinct caspase-8 activation pathways. Cell. 2008;133(4):693-703.

253. Chen Z, Chen J, Liu H, Dong W, Huang X, Yang D, et al. The SMAC mimetic APG-1387 sensitizes immune-mediated cell apoptosis in hepatocellular carcinoma. Front Pharmacol. 2018;9:1298.

254. Li BX, Wang HB, Qiu MZ, Luo QY, Yi HJ, Yan XL, et al. Novel smac mimetic APG-1387 elicits ovarian cancer cell killing through TNF-alpha, Ripoptosome and autophagy mediated cell death pathway. J Exp Clin Cancer Res. 2018;37(1):53.

255. Kamata E, Kawamoto T, Ueha T, Hara H, Fukase N, Minoda M, et al. Synergistic effects of a Smac mimetic with doxorubicin against human osteosarcoma. Anticancer Res. 2017;37(11):6097-106.

256. Lee EK, Jinesh GG, Laing NM, Choi W, McConkey DJ, Kamat AM. A Smac mimetic augments the response of urothelial cancer cells to gemcitabine and cisplatin. Cancer Biol Ther. 2013;14(9):812-22.

257. Brumatti G, Ma C, Lalaoui N, Nguyen NY, Navarro M, Tanzer MC, et al. The caspase-8 inhibitor emricasan combines with the SMAC mimetic birinapant to induce necroptosis and treat acute myeloid leukemia. Sci Transl Med. 2016;8(339):339ra369

258. Eytan DF, Snow GE, Carlson S, Derakhshan A, Saleh A, Schiltz S, et al. SMAC mimetic Birinapant plus radiation eradicates human head and neck cancers with genomic amplifications of cell death genes FADD and BIRC2. Cancer Res. 2016;76(18):5442-54.

259. Colombo M, Marabese M, Vargiu G, Broggini M, Caiola E. Activity of Birinapant, a SMAC mimetic compound, Alone or in Combination in NSCLCs With Different Mutations. Front Oncol. 2020;10:532292.

260. Noonan AM, Cousins A, Anderson D, Zeligs KP, Bunch K, Hernandez $L$, et al. Matrix drug screen identifies synergistic drug combinations to augment smac mimetic activity in ovarian cancer. Cancers (Basel). 2020;12(12):3784

261. Hernandez LF, Dull AB, Korrapati S, Annunziata CM. Smac-mimetic enhances antitumor effect of standard chemotherapy in ovarian cancer models via caspase 8-independent mechanism. Cell Death Discov. 2021;7(1):134

262. Lueck SC, Russ AC, Botzenhardt U, Schlenk RF, Zobel K, Deshayes K, et al. Smac mimetic induces cell death in a large proportion of primary acute myeloid leukemia samples, which correlates with defined molecular markers. Oncotarget. 2016;7(31):49539-51.

263. Seyfrid M, Marschall V, Fulda S. Reactive oxygen species contribute toward Smac mimetic/temozolomide-induced cell death in glioblastoma cells. Anti-Cancer Drugs. 2016;27(10):953-9.

264. Hehlgans S, Oppermann J, Reichert S, Fulda S, Rodel C, Rodel F. The SMAC mimetic BV6 sensitizes colorectal cancer cells to ionizing radiation by interfering with DNA repair processes and enhancing apoptosis. Radiat Oncol. 2015;10:198. 
265. Marschall V, Fulda S. Smac mimetic-induced upregulation of interferon-beta sensitizes glioblastoma to temozolomide-induced cell death. Cell Death Dis. 2015;6:e1888.

266. El-Mesery M, Shaker ME, Elgaml A. The SMAC mimetic BV6 induces cell death and sensitizes different cell lines to TNF-alpha and TRAILinduced apoptosis. Exp Biol Med (Maywood). 2016;241(18):2015-22

267. Reiter M, Eckhardt I, Haferkamp A, Fulda S. Smac mimetic sensitizes renal cell carcinoma cells to interferon-alpha-induced apoptosis. Cancer Lett. 2016;375(1):1-8.

268. Huerta S, Gao X, Livingston EH, Kapur P, Sun H, Anthony T. In vitro and in vivo radiosensitization of colorectal cancer HT-29 cells by the smac mimetic JP-1201. Surgery. 2010;148(2):346-53.

269. Dineen SP, Roland CL, Greer R, Carbon JG, Toombs JE, Gupta P, et al. Smac mimetic increases chemotherapy response and improves survival in mice with pancreatic cancer. Cancer Res. 2010;70(7):2852-61.

270. Runckel K, Barth MJ, Mavis C, Gu JJ, Hernandez-Ilizaliturri FJ. The SMAC mimetic LCL-161 displays antitumor activity in preclinical models of rituximab-resistant B-cell lymphoma. Blood Adv. 2018;2(23):3516-25.

271. Chang YC, Kondapuram SK, Yang TH, Syed SB, Cheng SM, Lin TY, et al. The SMAC mimetic LCL161 is a direct ABCB1/MDR1-ATPase activity modulator and BIRC5/Survivin expression down-regulator in cancer cells. Toxicol Appl Pharmacol. 2020;401:115080.

272. Yang L, Kumar B, Shen C, Zhao S, Blakaj D, Li T, et al. LCL161, a SMAC-mimetic, preferentially Radiosensitizes human papillomavirusnegative head and neck squamous cell carcinoma. Mol Cancer Ther. 2019;18(6):1025-35

273. Brands RC, Herbst F, Hartmann S, Seher A, Linz C, Kubler AC, et al. Cytotoxic effects of SMAC-mimetic compound LCL161 in head and neck cancer cell lines. Clin Oral Investig. 2016;20(9):2325-32.

274. Yang D, Zhao Y, Li AY, Wang S, Wang G, Sun Y. Smac-mimetic compound SM-164 induces radiosensitization in breast cancer cells through activation of caspases and induction of apoptosis. Breast Cancer Res Treat. 2012;133(1):189-99.

275. Lu J, McEachern D, Sun H, Bai L, Peng Y, Qiu S, et al. Therapeutic potential and molecular mechanism of a novel, potent, nonpeptide, Smac mimetic SM-164 in combination with TRAIL for cancer treatment. Mol Cancer Ther. 2011;10(5):902-14.

276. Zhou B, Zhang J, Chen G, You L, Zhang TP, Zhao YP. Therapy of Smac mimetic SM-164 in combination with gemcitabine for pancreatic cancer. Cancer Lett. 2013;329(1):118-24.

277. Metwalli AR, Khanbolooki S, Jinesh G, Sundi D, Shah JB, Shrader M, et al. Smac mimetic reverses resistance to TRAIL and chemotherapy in human urothelial cancer cells. Cancer Biol Ther. 2010;10(9):885-92.

278. Yang C, Ran Q, Zhou Y, Liu S, Zhao C, Yu X, et al. Doxorubicin sensitizes cancer cells to Smac mimetic via synergistic activation of the CYLD/RIPK1/FADD/caspase-8-dependent apoptosis. Apoptosis. 2020;25(5-6):441-55.

279. Tao Z, McCall NS, Wiedemann N, Vuagniaux G, Yuan Z, Lu B. SMAC mimetic Debio 1143 and ablative radiation therapy synergize to enhance antitumor immunity against lung Cancer. Clin Cancer Res. 2019;25(3):1113-24.

280. Dai Y, Liu M, Tang W, Li Y, Lian J, Lawrence TS, et al. A Smac-mimetic sensitizes prostate cancer cells to TRAIL-induced apoptosis via modulating both IAPs and NF-kappaB. BMC Cancer. 2009;9:392.

281. Hashim YM, Vangveravong S, Sankpal NV, Binder PS, Liu J, Goedegebuure SP, et al. The targeted SMAC mimetic SW IV-134 is a strong enhancer of standard chemotherapy in pancreatic cancer. J Exp Clin Cancer Res. 2017;36(1):14

282. Loeder S, Zenz T, Schnaiter A, Mertens D, Winkler D, Dohner H, et al. A novel paradigm to trigger apoptosis in chronic lymphocytic leukemia. Cancer Res. 2009;69(23):8977-86.

283. Fakler M, Loeder S, Vogler M, Schneider K, Jeremias I, Debatin KM, et al. Small molecule XIAP inhibitors cooperate with TRAIL to induce apoptosis in childhood acute leukemia cells and overcome Bcl2-mediated resistance. Blood. 2009;113(8):1710-22.

284. Fingas CD, Blechacz BR, Smoot RL, Guicciardi ME, Mott J, Bronk SF, et al. A smac mimetic reduces TNF related apoptosis inducing ligand (TRAIL)-induced invasion and metastasis of cholangiocarcinoma cells. Hepatology. 2010;52(2):550-61.
285. Vellanki SH, Grabrucker A, Liebau S, Proepper C, Eramo A, Braun V, et al. Small-molecule XIAP inhibitors enhance gamma-irradiation-induced apoptosis in glioblastoma. Neoplasia. 2009;11(8):743-52.

286. Steinhart L, Belz K, Fulda S. Smac mimetic and demethylating agents synergistically trigger cell death in acute myeloid leukemia cells and overcome apoptosis resistance by inducing necroptosis. Cell Death Dis. 2013;4:e802.

287. Carter BZ, Mak PY, Mak DH, Shi Y, Qiu Y, Bogenberger JM, et al. Synergistic targeting of AML stem/progenitor cells with IAP antagonist birinapant and demethylating agents. J Natl Cancer Inst. 2014;106(2):djt440.

288. Weisberg E, Kung AL, Wright RD, Moreno D, Catley L, Ray A, et al. Potentiation of antileukemic therapies by Smac mimetic, LBW242: effects on mutant FLT3-expressing cells. Mol Cancer Ther. 2007;6(7):1951-61.

289. Foster FM, Owens TW, Tanianis-Hughes J, Clarke RB, Brennan K, Bundred $\mathrm{NJ}$, et al. Targeting inhibitor of apoptosis proteins in combination with ErbB antagonists in breast cancer. Breast Cancer Res. 2009;11(3):R41.

290. Hao Q, Tang H. Interferon-gamma and Smac mimetics synergize to induce apoptosis of lung cancer cells in a TNFalpha-independent manner. Cancer Cell Int. 2018;18:84.

291. Ding J, Qin D, Zhang Y, Li Q, Li Y, Li J. SMAC mimetic birinapant inhibits hepatocellular carcinoma growth by activating the CIAP1/TRAF3 signaling pathway. Mol Med Rep. 2020;21(3):1251-7.

292. Lalaoui N, Merino D, Giner G, Vaillant F, Chau D, Liu L, et al. Targeting triple-negative breast cancers with the Smac-mimetic birinapant. Cell Death Differ. 2020;27(10):2768-80.

293. Wang Y, Wang Y, Fan X, Song J, Wu H, Han J, et al. ABT-199-mediated inhibition of $\mathrm{BCl}-2$ as a potential therapeutic strategy for nasopharyngeal carcinoma. Biochem Biophys Res Commun. 2018;503(3):1214-20.

294. Diaz-Flores E, Comeaux EQ, Kim KL, Melnik E, Beckman K, Davis KL, et al. $\mathrm{BCl}-2$ is a therapeutic target for Hypodiploid B-lineage acute lymphoblastic leukemia. Cancer Res. 2019:79(9):2339-51.

295. Guy JB, Espenel S, Louati S, Gauthier A, Garcia MA, Vial N, et al. Combining radiation to $\mathrm{EGFR}$ and $\mathrm{BCl}-2$ blockade: a new approach to target cancer stem cells in head and neck squamous cell carcinoma. J Cancer Res Clin Oncol. 2021;147(7):1905-16.

296. Bate-Eya LT, den Hartog IJ, van der Ploeg I, Schild L, Koster J, Santo EE, et al. High efficacy of the BCL-2 inhibitor ABT199 (venetoclax) in $\mathrm{BCL}-2$ high-expressing neuroblastoma cell lines and xenografts and rational for combination with MCL-1 inhibition. Oncotarget. 2016;7(19):27946-58

297. Bierbrauer A, Jacob M, Vogler M, Fulda S. A direct comparison of selective $\mathrm{BH} 3-$ mimetics reveals $\mathrm{BCL}-\mathrm{XL}, \mathrm{BCL}-2$ and $\mathrm{MCL}-1$ as promising therapeutic targets in neuroblastoma. Br J Cancer. 2020;122(10):1544-51.

298. Chen J, Zhou H, Aguilar A, Liu L, Bai L, McEachern D, et al. Structurebased discovery of BM-957 as a potent small-molecule inhibitor of Bcl-2 and $\mathrm{BCl}-\mathrm{xL}$ capable of achieving complete tumor regression. J Med Chem. 2012;55(19):8502-14.

299. Bai L, Chen J, McEachern D, Liu L, Zhou H, Aguilar A, et al. BM-1197: a novel and specific BCl-2/BCl-xL inhibitor inducing complete and longlasting tumor regression in vivo. PLoS One. 2014;9(6):e99404.

300. Pan R, Hogdal LJ, Benito JM, Bucci D, Han L, Borthakur G, et al. Selective BCL-2 inhibition by ABT-199 causes on-target cell death in acute myeloid leukemia. Cancer Discov. 2014:4(3):362-75.

301. Zhou Y, Liu H, Xue R, Tang W, Zhang S. BH3 mimetic ABT-199 enhances the sensitivity of gemcitabine in pancreatic Cancer in vitro and in vivo. Dig Dis Sci. 2018;63(12):3367-75.

302. Peirs S, Matthijssens F, Goossens S, Van de Walle I, Ruggero K, de Bock CE, et al. ABT-199 mediated inhibition of BCL-2 as a novel therapeutic strategy in T-cell acute lymphoblastic leukemia. Blood. 2014;124(25):3738-47.

303. Niu X, Zhao J, Ma J, Xie C, Edwards H, Wang G, et al. Binding of released Bim to $\mathrm{Mcl}-1$ is a mechanism of intrinsic resistance to ABT-199 which can be overcome by combination with Daunorubicin or Cytarabine in AML cells. Clin Cancer Res. 2016;22(17):4440-51.

304. Li Z, He S, Look AT. The MCL1-specific inhibitor 563845 acts synergistically with venetoclax/ABT-199 to induce apoptosis in T-cell acute lymphoblastic leukemia cells. Leukemia. 2019;33(1):262-6.

305. Shi YF, Liu L, He LL, Ye J, Lin ZJ, Yuan DL, et al. Combining triptolide with ABT-199 is effective against acute myeloid leukemia through reciprocal regulation of $\mathrm{BCl}-2$ family proteins and activation of the intrinsic apoptotic pathway. Cell Death Dis. 2020;11(7):555. 
306. Xiufeng Z, Haijun Z, Silei B, Manman D, Yong Z, Lian Y, et al. Cooperation of ABT-199 and gemcitabine in impeding DNA damage repair and inducing cell apoptosis for synergistic therapy of T-cell acute lymphoblastic leukemia. Anti-Cancer Drugs. 2019;30(2):138-48.

307. Wang X, Mak PY, Mu H, Tao W, Rao A, Visweswaran R, et al. Combinatorial inhibition of focal adhesion kinase and BCL-2 enhances antileukemia activity of Venetoclax in acute myeloid leukemia. Mol Cancer Ther. 2020;19(8):1636-48.

308. Vaillant F, Merino D, Lee L, Breslin K, Pal B, Ritchie ME, et al. Targeting $\mathrm{BCL}-2$ with the $\mathrm{BH} 3$ mimetic $\mathrm{ABT}-199$ in estrogen receptor-positive breast cancer. Cancer Cell. 2013;24(1):120-9.

309. Ko TK, Chuah CT, Huang JW, Ng KP, Ong ST. The BCL2 inhibitor ABT199 significantly enhances imatinib-induced cell death in chronic myeloid leukemia progenitors. Oncotarget. 2014;5(19):9033-8.

310. Yu Z, Du J, Zhao Y, Gao Y, Li Y, Zhao K, et al. A novel kinase inhibitor, LZT-106, downregulates Mcl-1 and sensitizes colorectal cancer cells to BH3 mimetic ABT-199 by targeting CDK9 and GSK-3beta signaling. Cancer Lett. 2021:498:31-41.

311. Kuo HP, Ezell SA, Schweighofer KJ, Cheung LWK, Hsieh S, Apatira $M$, et al. Combination of Ibrutinib and ABT-199 in diffuse large B-cell lymphoma and follicular lymphoma. Mol Cancer Ther. 2017;16(7):1246-56.

312. Phillips DC, Jin S, Gregory GP, Zhang Q, Xue J, Zhao X, et al. A novel CDK9 inhibitor increases the efficacy of venetoclax (ABT199) in multiple models of hematologic malignancies. Leukemia. 2020;34(6):1646-57.

313. Zhang Y, Zhou L, Bandyopadhyay D, Sharma K, Allen AJ, Kmieciak M, et al. The covalent CDK7 inhibitor THZ1 potently induces apoptosis in multiple myeloma cells in vitro and in vivo. Clin Cancer Res. 2019;25(20):6195-205.

314. Zhou L, Zhang Y, Sampath D, Leverson J, Dai Y, Kmieciak M, et al. Flavopiridol enhances ABT-199 sensitivity in unfavourable-risk multiple myeloma cells in vitro and in vivo. Br J Cancer. 2018;118(3):388-97.

315. Muenchow A, Weller S, Hinterleitner C, Malenke E, Bugl S, Wirths $\mathrm{S}$, et al. The BCL-2 selective inhibitor ABT-199 sensitizes soft tissue sarcomas to proteasome inhibition by a concerted mechanism requiring BAX and NOXA. Cell Death Dis. 2020;11(8):701.

316. Zhang B, Gojo I, Fenton RG. Myeloid cell factor-1 is a critical survival factor for multiple myeloma. Blood. 2002;99(6):1885-93.

317. Kozopas KM, Yang T, Buchan HL, Zhou P, Craig RW. MCL1, a gene expressed in programmed myeloid cell differentiation, has sequence similarity to BCL2. Proc Natl Acad Sci U S A. 1993;90(8):3516-20.

318. Lomo J, Smeland EB, Krajewski S, Reed JC, Blomhoff HK. Expression of the $\mathrm{BCl}-2$ homologue $\mathrm{MCl}-1$ correlates with survival of peripheral blood B lymphocytes. Cancer Res. 1996;56(1):40-3.

319. Zhou P, Qian L, Bieszczad CK, Noelle R, Binder M, Levy NB, et al. MCl-1 in transgenic mice promotes survival in a spectrum of hematopoietic cell types and immortalization in the myeloid lineage. Blood. 1998;92(9):3226-39.

320. Opferman JT, Letai A, Beard C, Sorcinelli MD, Ong CC, Korsmeyer SJ. Development and maintenance of $B$ and $T$ lymphocytes requires antiapoptotic MCL-1. Nature. 2003;426(6967):671-6.

321. Perciavalle RM, Stewart DP, Koss B, Lynch J, Milasta S, Bathina M, et al. Anti-apoptotic MCL-1 localizes to the mitochondrial matrix and couples mitochondrial fusion to respiration. Nat Cell Biol. 2012;14(6):575-83.

322. Fujise K, Zhang D, Liu J, Yeh ET. Regulation of apoptosis and cell cycle progression by MCL1. Differential role of proliferating cell nuclear antigen. J Biol Chem. 2000;275(50):39458-65.

323. Jamil S, Mojtabavi S, Hojabrpour P, Cheah S, Duronio V. An essential role for MCL-1 in ATR-mediated CHK1 phosphorylation. Mol Biol Cell. 2008;19(8):3212-20.

324. Bingle CD, Craig RW, Swales BM, Singleton V, Zhou P, Whyte MK. Exon skipping in $\mathrm{Mcl}-1$ results in a bcl-2 homology domain 3 only gene product that promotes cell death. J Biol Chem. 2000;275(29):22136-46.

325. Bae J, Leo CP, Hsu SY, Hsueh AJ. MCL-1S, a splicing variant of the antiapoptotic $B C L-2$ family member $M C L-1$, encodes a proapoptotic protein possessing only the BH3 domain. J Biol Chem. 2000;275(33):25255-61.

326. Morciano G, Giorgi C, Balestra D, Marchi S, Perrone D, Pinotti M, et al. $\mathrm{MCl}-1$ involvement in mitochondrial dynamics is associated with apoptotic cell death. Mol Biol Cell. 2016;27(1):20-34.
327. Kim JH, Sim SH, Ha HJ, Ko JJ, Lee K, Bae J. MCL-1ES, a novel variant of $\mathrm{MCL}-1$, associates with MCL-1L and induces mitochondrial cell death. FEBS Lett. 2009;583(17):2758-64.

328. Uhlen M, Fagerberg L, Hallstrom BM, Lindskog C, Oksvold P, Mardinoglu A, et al. Proteomics. Tissue-based map of the human proteome. Science. 2015;347(6220):1260419.

329. Fernandez-Marrero Y, Spinner S, Kaufmann T, Jost PJ. Survival control of malignant lymphocytes by anti-apoptotic MCL-1. Leukemia. 2016;30(11):2152-9.

330. Sieghart W, Losert D, Strommer S, Cejka D, Schmid K, Rasoul-Rockenschaub S, et al. Mcl-1 overexpression in hepatocellular carcinoma: a potential target for antisense therapy. J Hepatol. 2006;44(1):151-7.

331. Lin J, Fu D, Dai Y, Lin J, Xu T. MCl-1 inhibitor suppresses tumor growth of esophageal squamous cell carcinoma in a mouse model. Oncotarget. 2017;8(70):114457-62.

332. Campbell KJ, Dhayade S, Ferrari N, Sims AH, Johnson E, Mason SM, et al. $\mathrm{MCL}-1$ is a prognostic indicator and drug target in breast cancer. Cell Death Dis. 2018:9(2):19.

333. Hosseini A, Espona-Fiedler M, Soto-Cerrato V, Quesada R, Perez-Tomas R, Guallar V. Molecular interactions of prodiginines with the $\mathrm{BH} 3$ domain of anti-apoptotic BCl-2 family members. PLoS One. 2013;8(2):e57562.

334. Opferman JT, Iwasaki H, Ong CC, Suh H, Mizuno S, Akashi K, et al. Obligate role of anti-apoptotic MCL-1 in the survival of hematopoietic stem cells. Science. 2005;307(5712):1101-4.

335. Abdul Rahman SF, Muniandy K, Soo YK, Tiew EYH, Tan KX, Bates TE, et al. Co-inhibition of $\mathrm{BCL}-\mathrm{XL}$ and $\mathrm{MCL}-1$ with selective $\mathrm{BCL}-2$ family inhibitors enhances cytotoxicity of cervical cancer cell lines. Biochem Biophys Rep. 2020;22:100756.

336. Szlavik Z, Csekei M, Paczal A, Szabo ZB, Sipos S, Radics G, et al. Discovery of S64315, a potent and selective Mcl-1 inhibitor. J Med Chem. 2020:63(22):13762-95.

337. Luedtke DA, Niu X, Pan Y, Zhao J, Liu S, Edwards H, et al. Inhibition of MCl-1 enhances cell death induced by the BCl-2-selective inhibitor ABT-199 in acute myeloid leukemia cells. Signal Transduct Target Ther. 2017:2:17012

338. De Blasio A, Pratelli G, Drago-Ferrante R, Saliba C, Baldacchino S, Grech G, et al. Loss of MCL1 function sensitizes the MDA-MB-231 breast cancer cells to rh-TRAIL by increasing DR4 levels. J Cell Physiol. 2019;234(10):18432-47.

339. Song S, Kim S, El-Sawy ER, Cerella C, Orlikova-Boyer B, Kirsch G, et al. Anti-leukemic properties of aplysinopsin derivative ee-84 alone and combined to bh3 mimetic a-1210477. Mar Drugs. 2021;19(6):285.

340. Kawakami H, Huang S, Pal K, Dutta SK, Mukhopadhyay D, Sinicrope FA. Mutant BRAF upregulates $\mathrm{MCL}-1$ to confer apoptosis resistance that is reversed by MCL-1 antagonism and Cobimetinib in colorectal Cancer. Mol Cancer Ther. 2016;15(12):3015-27.

341. Quentmeier H, Drexler HG, Hauer V, MacLeod RA, Pommerenke C, Uphoff CC, et al. Diffuse large B cell lymphoma cell line U-2946: model for MCL1 inhibitor testing. PLoS One. 2016;11(12):e0167599.

342. OWTJ, Fulcher CD, Thomas C, Broin PO, Lopez A, Reyna DE, et al. Optimal targeting of $\mathrm{BCL}$-family proteins in head and neck squamous cell carcinoma requires inhibition of both $\mathrm{BCL}-\mathrm{xL}$ and $\mathrm{MCL}-1$. Oncotarget. 2019:10(4):494-510.

343. Phillips DC, Xiao Y, Lam LT, Litvinovich E, Roberts-Rapp L, Souers AJ, et al. Loss in MCL-1 function sensitizes non-Hodgkin's lymphoma cell lines to the BCL-2-selective inhibitor venetoclax (ABT-199). Blood Cancer J. 2015;5:e368

344. Yi X, Sarkar A, Kismali G, Aslan B, Ayres M, Iles LR, et al. AMG-176, an $\mathrm{MCl}-1$ antagonist, shows preclinical efficacy in chronic lymphocytic leukemia. Clin Cancer Res. 2020;26(14):3856-67.

345. Carter BZ, Mak PY, Tao W, Warmoes M, Lorenzi PL, Mak D, et al. Targeting MCL-1 dysregulates cell metabolism and leukemia-stroma interactions and resensitizes acute myeloid leukemia to $\mathrm{BCL}-2$ inhibition. Haematologica. 2020; https://doi.org/10.3324/haematol.2020.260331.

346. Zheng L, Yang W, Zhang C, Ding WJ, Zhu H, Lin NM, et al. GDC-0941 sensitizes breast cancer to ABT-737 in vitro and in vivo through promoting the degradation of Mcl-1. Cancer Lett. 2011;309(1):27-36.

347. Respondek M, Beberok A, Rok J, Rzepka Z, Wrzesniok D, Buszman E. MIM1, the MCl-1 - specific BH3 mimetic induces apoptosis in human U87MG glioblastoma cells. Toxicol in Vitro. 2018;53:126-35. 
348. Respondek M, Beberok A, Rzepka Z, Rok J, Wrzesniok D. Mcl-1 inhibitor induces cells death in BRAF-mutant Amelanotic melanoma trough GSH depletion, DNA damage and cell cycle changes. Pathol Oncol Res. 2020;26(3):1465-74.

349. Respondek M, Beberok A, Rzepka Z, Rok J, Wrzesniok D. MIM1 induces COLO829 melanoma cell death through mitochondrial membrane breakdown, GSH depletion, and DNA damage. Fundam Clin Pharmacol. 2020;34(1):20-31.

350. Seipel K, Schmitter K, Bacher U, Pabst T. Rationale for a combination therapy consisting of MCL1- and MEK-Inhibitors in Acute Myeloid Leukemia. Cancers (Basel). 2019;11(11):1779.

351. Grundy M, Balakrishnan S, Fox M, Seedhouse CH, Russell NH. Genetic biomarkers predict response to dual $\mathrm{BCL}-2$ and $\mathrm{MCL}-1$ targeting in acute myeloid leukaemia cells. Oncotarget. 2018;9(102):37777-89.

352. Seipel K, Kopp B, Bacher U, Pabst T. BMI1-Inhibitor PTC596 in Combination with MCL1 Inhibitor S63845 or MEK Inhibitor Trametinib in the Treatment of Acute Leukemia. Cancers (Basel). 2021;13(3):581-96.

353. Hormi M, Birsen R, Belhadj M, Huynh T, Cantero Aguilar L, Grig-

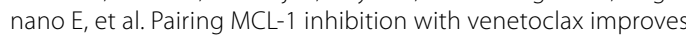
therapeutic efficiency of BH3-mimetics in AML. Eur J Haematol. 2020;105(5):588-96.

354. Merino D, Whittle JR, Vaillant F, Serrano A, Gong JN, Giner G, et al. Synergistic action of the MCL-1 inhibitor 563845 with current therapies in preclinical models of triple-negative and HER2-amplified breast cancer. Sci Transl Med. 2017;9(401). https://doi.org/10.1126/ scitransImed.aam7049.

355. Song X, Shen L, Tong J, Kuang C, Zeng S, Schoen RE, et al. MCl-1 inhibition overcomes intrinsic and acquired regorafenib resistance in colorectal cancer. Theranostics. 2020;10(18):8098-110.

356. Prukova D, Andera L, Nahacka Z, Karolova J, Svaton M, Klanova M, et al. Cotargeting of BCL2 with Venetoclax and MCL1 with $\mathrm{S} 63845$ is synthetically lethal in vivo in relapsed mantle cell lymphoma. Clin Cancer Res. 2019;25(14):4455-65.

357. Mukherjee N, Skees J, Todd KJ, West DA, Lambert KA, Robinson WA, et al. MCL1 inhibitors S63845/MIK665 plus Navitoclax synergistically kill difficult-to-treat melanoma cells. Cell Death Dis. 2020;11(6):443.

358. Sarif Z, Tolksdorf B, Fechner H, Eberle J. Mcl-1 targeting strategies unlock the proapoptotic potential of TRAIL in melanoma cells. Mol Carcinog. 2020;59(11):1256-68.

359. Seiller C, Maiga S, Touzeau C, Bellanger C, Kervoelen C, Descamps G, et al. Dual targeting of $B C L 2$ and $M C L 1$ rescues myeloma cells resistant to BCL2 and MCL1 inhibitors associated with the formation of BAX/BAK hetero-complexes. Cell Death Dis. 2020;11(5):316.

360. Wong KY, Chim CS. Venetoclax, bortezomib and S63845, an MCL1 inhibitor, in multiple myeloma. J Pharm Pharmacol. 2020;72(5):728-37.

361. Algarin EM, Diaz-Tejedor A, Mogollon P, Hernandez-Garcia S, Corchete $L A$, San-Segundo $L$, et al. Preclinical evaluation of the simultaneous inhibition of MCL-1 and BCL-2 with the combination of S63845 and venetoclax in multiple myeloma. Haematologica. 2020;105(3):e116-20.

362. Williams MM, Elion DL, Rahman B, Hicks DJ, Sanchez V, Cook RS. Therapeutic inhibition of $\mathrm{Mcl}-1$ blocks cell survival in estrogen receptorpositive breast cancers. Oncotarget. 2019;10(52):5389-402.

363. Lu X, Liang H, Orvig C, Chen ZF. Peptide and Small Molecule Inhibitors Targeting Myeloid Cell Leukemia 1 (Mcl-1) as Novel Antitumor Agents. Curr Mol Med. 2021;21(5):426-39.

364. Wei AH, Roberts AW, Spencer A, Rosenberg AS, Siegel D, Walter RB, et al. Targeting $\mathrm{MCL}-1$ in hematologic malignancies: rationale and progress. Blood Rev. 2020;44:100672.

365. Zhang H, Nakauchi Y, Kohnke T, Stafford M, Bottomly D, Thomas R, et al. Integrated analysis of patient samples identifies biomarkers for venetoclax efficacy and combination strategies in acute myeloid leukemia. Nat Cancer. 2020;1(8):826-39.

366. Arulananda S, O'Brien M, Evangelista M, Jenkins LJ, Poh AR, Walkiewicz $\mathrm{M}$, et al. A novel BH3-mimetic, AZD0466, targeting BCL-XL and BCL-2 is effective in pre-clinical models of malignant pleural mesothelioma. Cell Death Discov. 2021;7(1):122.

367. Letai A. S63845, an MCL-1 selective BH3 mimetic: another arrow in our quiver. Cancer Cell. 2016;30(6):834-5.
368. Bala Tannan N, Manzari MT, Herviou L, Da Silva FM, Hagen C, Kiguchi H, et al. Tumor-targeted nanoparticles improve the therapeutic index of BCL2 and MCL1 dual inhibition. Blood. 2021:137(15):2057-69.

369. Michels J, Obrist F, Vitale I, Lissa D, Garcia P, Behnam-Motlagh P, et al. MCL-1 dependency of cisplatin-resistant cancer cells. Biochem Pharmacol. 2014;92(1):55-61.

370. Tromp JM, Geest CR, Breij EC, Elias JA, van Laar J, Luijks DM, et al. Tipping the Noxa/Mcl-1 balance overcomes ABT-737 resistance in chronic lymphocytic leukemia. Clin Cancer Res. 2012;18(2):487-98.

371. Bates DJ, Danilov AV, Lowrey $\mathrm{CH}$, Eastman A. Vinblastine rapidly induces NOXA and acutely sensitizes primary chronic lymphocytic leukemia cells to ABT-737. Mol Cancer Ther. 2013;12(8):1504-14.

372. Jane EP, Premkumar DR, Cavaleri JM, Sutera PA, Rajasekar T, Pollack IF. Dinaciclib, a cyclin-dependent kinase inhibitor promotes proteasomal degradation of Mcl-1 and enhances ABT-737-mediated cell death in malignant human glioma cell lines. J Pharmacol Exp Ther. 2016;356(2):354-65.

373. Sulkshane P, Teni T. BH3 mimetic Obatoclax (GX15-070) mediates mitochondrial stress predominantly via $\mathrm{MCL}-1$ inhibition and induces autophagy-dependent necroptosis in human oral cancer cells. Oncotarget. 2017:8(36):60060-79.

374. Garner TP, Lopez A, Reyna DE, Spitz AZ, Gavathiotis E. Progress in targeting the BCL-2 family of proteins. Curr Opin Chem Biol. 2017;39:133-42.

375. Robin AY, Krishna Kumar K, Westphal D, Wardak AZ, Thompson GV, Dewson $\mathrm{G}$, et al. Crystal structure of Bax bound to the $\mathrm{BH} 3$ peptide of Bim identifies important contacts for interaction. Cell Death Dis. 2015:6:e1809.

376. Garner TP, Reyna DE, Priyadarshi A, Chen HC, Li S, Wu Y, et al. An autoinhibited dimeric form of BAX regulates the BAX activation pathway. Mol Cell. 2016;63(3):485-97.

377. Hadji A, Schmitt GK, Schnorenberg MR, Roach L, Hickey CM, Leak LB, et al. Preferential targeting of MCL-1 by a hydrocarbon-stapled BIM BH3 peptide. Oncotarget. 2019;10(58):6219-33.

378. Lee EF, Czabotar PE, van Delft MF, Michalak EM, Boyle MJ, Willis SN, et al. A novel $\mathrm{BH} 3$ ligand that selectively targets $\mathrm{MCl}-1$ reveals that apoptosis can proceed without Mcl-1 degradation. J Cell Biol. 2008;180(2):341-55.

379. Kritzer JA. The secret of MIM: a novel, MCL-1-specific small molecule. Chem Biol. 2012;19(9):1082-3.

380. Trudel S, Li ZH, Rauw J, Tiedemann RE, Wen XY, Stewart AK. Preclinical studies of the pan-Bcl inhibitor obatoclax (GX015-070) in multiple myeloma. Blood. 2007;109(12):5430-8.

381. Zhang M, Liu H, Guo R, Ling Y, Wu X, Li B, et al. Molecular mechanism of gossypol-induced cell growth inhibition and cell death of HT-29 human colon carcinoma cells. Biochem Pharmacol. 2003;66(1):93-103.

382. Certo M, Del Gaizo MV, Nishino M, Wei G, Korsmeyer S, Armstrong $\mathrm{SA}$, et al. Mitochondria primed by death signals determine cellular addiction to antiapoptotic BCL-2 family members. Cancer Cell. 2006;9(5):351-65.

383. Khan S, Zhang X, Lv D, Zhang Q, He Y, Zhang P, et al. A selective BCL-XL PROTAC degrader achieves safe and potent antitumor activity. Nat Med. 2019;25(12):1938-47.

384. Dutta S, Ryan J, Chen TS, Kougentakis C, Letai A, Keating AE. Potent and specific peptide inhibitors of human pro-survival protein $\mathrm{BCl}-\mathrm{xL}$. J Mol Biol. 2015;427(6 Pt B):1241-53.

385. Mitchell WB, Pinheiro MP, Boulad N, Kaplan D, Edison MN, Psaila B, et al. Effect of thrombopoietin receptor agonists on the apoptotic profile of platelets in patients with chronic immune thrombocytopenia. Am J Hematol. 2014:89(12):E228-34.

386. Brinkmann K, Kashkar H. Targeting the mitochondrial apoptotic pathway: a preferred approach in hematologic malignancies? Cell Death Dis. 2014;5:e1098

387. Suvarna $\vee$, Singh V, Murahari M. Current overview on the clinical update of Bcl-2 anti-apoptotic inhibitors for cancer therapy. Eur J Pharmacol. 2019:862:172655.

388. Xiong H, Pradhan RS, Nada A, Krivoshik AP, Holen KD, Rhodes JW, et al. Studying navitoclax, a targeted anticancer drug, in healthy volunteers-ethical considerations and risk/benefit assessments and management. Anticancer Res. 2014;34(7):3739-46.

389. Wilson WH, O'Connor OA, Czuczman MS, LaCasce AS, Gerecitano JF, Leonard JP, et al. Navitoclax, a targeted high-affinity inhibitor of BCL-2, in lymphoid malignancies: a phase 1 dose-escalation study of safety, 
pharmacokinetics, pharmacodynamics, and antitumour activity. Lancet Oncol. 2010;11(12):1149-59.

390. Gandhi L, Camidge DR, Ribeiro de Oliveira M, Bonomi P, Gandara D, Khaira D, et al. Phase I study of Navitoclax (ABT-263), a novel BCl-2 family inhibitor, in patients with small-cell lung cancer and other solid tumors. J Clin Oncol. 2011;29(7):909-16.

391. Roberts AW, Seymour JF, Brown JR, Wierda WG, Kipps TJ, Khaw SL, et al. Substantial susceptibility of chronic lymphocytic leukemia to BCL2 inhibition: results of a phase I study of navitoclax in patients with relapsed or refractory disease. J Clin Oncol. 2012;30(5):488-96.

392. Puglisi M, Molife LR, de Jonge MJ, Khan KH, Doorn LV, Forster MD, et al. A phase I study of the safety, pharmacokinetics and efficacy of navitoclax plus docetaxel in patients with advanced solid tumors. Future Oncol. 2021;17(21):2747-58.

393. Tolcher AW, LoRusso P, Arzt J, Busman TA, Lian G, Rudersdorf NS, et al. Safety, efficacy, and pharmacokinetics of navitoclax (ABT-263) in combination with erlotinib in patients with advanced solid tumors. Cancer Chemother Pharmacol. 2015;76(5):1025-32.

394. Cleary JM, Lima CM, Hurwitz HI, Montero AJ, Franklin C, Yang J, et al. A phase I clinical trial of navitoclax, a targeted high-affinity $\mathrm{BCl}-2$ family inhibitor, in combination with gemcitabine in patients with solid tumors. Investig New Drugs. 2014;32(5):937-45.

395. Vlahovic G, Karantza V, Wang D, Cosgrove D, Rudersdorf N, Yang J, et al. A phase I safety and pharmacokinetic study of ABT-263 in combination with carboplatin/paclitaxel in the treatment of patients with solid tumors. Investig New Drugs. 2014;32(5):976-84.

396. Pietanza MC, Rudin CM. Novel therapeutic approaches for small cell lung cancer: the future has arrived. Curr Probl Cancer. 2012;36(3):156-73.

397. de Vos S, Leonard JP, Friedberg JW, Zain J, Dunleavy K, Humerickhouse $R$, et al. Safety and efficacy of navitoclax, a BCL-2 and BCL-XL inhibitor, in patients with relapsed or refractory lymphoid malignancies: results from a phase 2a study. Leuk Lymphoma. 2021;62(4):810-8.

398. Yang J, Pradhan RS, Rosen LS, Graham AM, Holen KD, Xiong H. Effect of rifampin on the pharmacokinetics, safety and tolerability of navitoclax (ABT-263), a dual inhibitor of $\mathrm{BCl}-2$ and $\mathrm{BCl}-\mathrm{XL}$, in patients with cancer. J Clin Pharm Ther. 2014;39(6):680-4.

399. Roberts AW, Advani RH, Kahl BS, Persky D, Sweetenham JW, Carney DA, et al. Phase 1 study of the safety, pharmacokinetics, and antitumour activity of the BCL2 inhibitor navitoclax in combination with rituximab in patients with relapsed or refractory $\mathrm{CD} 20+$ lymphoid malignancies. Br J Haematol. 2015:170(5):669-78

400. Kipps TJ, Eradat H, Grosicki S, Catalano J, Cosolo W, Dyagil IS, et al. A phase 2 study of the BH3 mimetic BCL2 inhibitor navitoclax (ABT-263) with or without rituximab, in previously untreated B-cell chronic lymphocytic leukemia. Leuk Lymphoma. 2015;56(10):2826-33.

401. Stein MN, Goodin S, Gounder M, Gibbon D, Moss R, Portal D, et al. A phase I study of AT-101, a BH3 mimetic, in combination with paclitaxel and carboplatin in solid tumors. Investig New Drugs. 2020:38(3):855-65.

402. Vogler M, Weber K, Dinsdale D, Schmitz I, Schulze-Osthoff K, Dyer MJ, et al. Different forms of cell death induced by putative BCL2 inhibitors. Cell Death Differ. 2009;16(7):1030-9.

403. Wroblewski D, Jiang CC, Croft A, Farrelly ML, Zhang XD, Hersey P. OBATOCLAX and ABT-737 induce ER stress responses in human melanoma cells that limit induction of apoptosis. PLoS One. 2013;8(12):e84073.

404. Heidari N, Hicks MA, Harada H. GX15-070 (obatoclax) overcomes glucocorticoid resistance in acute lymphoblastic leukemia through induction of apoptosis and autophagy. Cell Death Dis. 2010;1:e76.

405. Urtishak KA, Edwards AY, Wang LS, Hudome A, Robinson BW, Barrett $J \mathrm{~S}$, et al. Potent obatoclax cytotoxicity and activation of triple death mode killing across infant acute lymphoblastic leukemia. Blood. 2013;121(14):2689-703.

406. Basit F, Cristofanon S, Fulda S. Obatoclax (GX15-070) triggers necroptosis by promoting the assembly of the necrosome on autophagosomal membranes. Cell Death Differ. 2013;20(9):1161-73.

407. Su JC, Chen KF, Chen WL, Liu CY, Huang JW, Tai WT, et al. Synthesis and biological activity of obatoclax derivatives as novel and potent SHP-1 agonists. Eur J Med Chem. 2012;56:127-33.

408. Schimmer AD, Raza A, Carter TH, Claxton D, Erba H, DeAngelo DJ, et al. A multicenter phase $1 / / 1$ study of obatoclax mesylate administered as a
3- or 24-hour infusion in older patients with previously untreated acute myeloid leukemia. PLoS One. 2014;9(10):e108694.

409. Langer CJ, Albert I, Ross HJ, Kovacs P, Blakely LJ, Pajkos G, et al. Randomized phase II study of carboplatin and etoposide with or without obatoclax mesylate in extensive-stage small cell lung cancer. Lung Cancer. 2014;85(3):420-8.

410. Arellano ML, Borthakur G, Berger M, Luer J, Raza A. A phase II, multicenter, open-label study of obatoclax mesylate in patients with previously untreated myelodysplastic syndromes with anemia or thrombocytopenia. Clin Lymphoma Myeloma Leuk. 2014;14(6):534-9.

411. Oki Y, Copeland A, Hagemeister F, Fayad LE, Fanale M, Romaguera J, et al. Experience with obatoclax mesylate (GX15-070), a small molecule pan-BCl-2 family antagonist in patients with relapsed or refractory classical Hodgkin lymphoma. Blood. 2012;119(9):2171-2.

412. Paik PK, Rudin CM, Pietanza MC, Brown A, Rizvi NA, Takebe N, et al. A phase II study of obatoclax mesylate, a BCl-2 antagonist, plus topotecan in relapsed small cell lung cancer. Lung Cancer. 2011;74(3):481-5.

413. Parikh SA, Kantarjian H, Schimmer A, Walsh W, Asatiani E, El-Shami K et al. Phase II study of obatoclax mesylate (GX15-070), a small-molecule BCL-2 family antagonist, for patients with myelofibrosis. Clin Lymphoma Myeloma Leuk. 2010;10(4):285-9.

414. O'Brien SM, Claxton DF, Crump M, Faderl S, Kipps T, Keating MJ, et al. Phase I study of obatoclax mesylate (GX15-070), a small molecule pan$\mathrm{BCl}-2$ family antagonist, in patients with advanced chronic lymphocytic leukemia. Blood. 2009;113(2):299-305.

415. Schimmer AD, O'Brien S, Kantarjian H, Brandwein J, Cheson BD, Minden $\mathrm{MD}$, et al. A phase I study of the pan bcl-2 family inhibitor obatoclax mesylate in patients with advanced hematologic malignancies. Clin Cancer Res. 2008;14(24):8295-301.

416. Zhang L, Ming L, Yu J. BH3 mimetics to improve cancer therapy; mechanisms and examples. Drug Resist Updat. 2007:10(6):207-17.

417. Goy A, Hernandez-IIzaliturri FJ, Kahl B, Ford P, Protomastro E, Berger M. A phase I/II study of the pan $\mathrm{BCl}-2$ inhibitor obatoclax mesylate plus bortezomib for relapsed or refractory mantle cell lymphoma. Leuk Lymphoma. 2014;55(12):2761-8.

418. Infante JR, Dees EC, Olszanski AJ, Dhuria SV, Sen S, Cameron S, et al. Phase I dose-escalation study of LCL161, an oral inhibitor of apoptosis proteins inhibitor, in patients with advanced solid tumors. J Clin Oncol. 2014;32(28):3103-10.

419. Ikeda F, Deribe YL, Skanland SS, Stieglitz B, Grabbe C, Franz-Wachtel M, et al. SHARPIN forms a linear ubiquitin ligase complex regulating NFkappaB activity and apoptosis. Nature. 2011:471(7340):637-41.

420. Gerlach B, Cordier SM, Schmukle AC, Emmerich CH, Rieser E, Haas $\mathrm{TL}$, et al. Linear ubiquitination prevents inflammation and regulates immune signalling. Nature. 2011:471(7340):591-6.

421. Tokunaga F, Nakagawa T, Nakahara M, Saeki Y, Taniguchi M, Sakata $\mathrm{S}$, et al. SHARPIN is a component of the NF-kappaB-activating linear ubiquitin chain assembly complex. Nature. 2011;471(7340):633-6.

422. Beug ST, Tang VA, LaCasse EC, Cheung HH, Beauregard CE, Brun J, et al. Smac mimetics and innate immune stimuli synergize to promote tumor death. Nat Biotechnol. 2014;32(2):182-90.

423. Borthakur G, Odenike O, Aldoss I, Rizzieri DA, Prebet T, Chen C, et al. A phase 1 study of the pan-bromodomain and extraterminal inhibitor mivebresib (ABBV-075) alone or in combination with venetoclax in patients with relapsed/refractory acute myeloid leukemia. Cancer. 2021;127(16):2943-53.

424. Piha-Paul SA, Sachdev JC, Barve M, LoRusso P, Szmulewitz R, Patel SP, et al. First-in-human study of Mivebresib (ABBV-075), an Oral Paninhibitor of Bromodomain and extra terminal proteins, in patients with relapsed/refractory solid tumors. Clin Cancer Res. 2019;25(21):6309-19.

425. Morschhauser F, Feugier P, Flinn IW, Gasiorowski R, Greil R, Illes A, et al. A phase 2 study of venetoclax plus R-CHOP as first-line treatment for patients with diffuse large B-cell lymphoma. Blood. 2021;137(5):600-9.

426. Zelenetz AD, Salles G, Mason KD, Casulo C, Le Gouill S, Sehn LH, et al. Venetoclax plus R- or G-CHOP in non-Hodgkin lymphoma: results from the CAVALLI phase 1b trial. Blood. 2019;133(18):1964-76.

427. Zinzani PL, Flinn IW, Yuen SLS, Topp MS, Rusconi C, Fleury I, et al. Venetoclax-rituximab with or without bendamustine vs bendamustine-rituximab in relapsed/refractory follicular lymphoma. Blood. 2020;136(23):2628-37. 
428. Izutsu K, Yamamoto K, Kato K, Ishikawa T, Fukuhara N, Terui Y, et al. Phase $1 / 2$ study of venetoclax, a BCL-2 inhibitor, in Japanese patients with relapsed or refractory chronic lymphocytic leukemia and small lymphocytic lymphoma. Int J Hematol. 2021;113(3):370-80,

429. Flinn IW, Gribben JG, Dyer MJS, Wierda W, Maris MB, Furman RR, et al. Phase $1 \mathrm{~b}$ study of venetoclax-obinutuzumab in previously untreated and relapsed/refractory chronic lymphocytic leukemia. Blood. 2019;133(26):2765-75.

430. Wei AH, Strickland SA Jr, Hou JZ, Fiedler W, Lin TL, Walter RB, et al. Venetoclax combined with low-dose Cytarabine for previously untreated patients with acute myeloid leukemia: results from a phase Ib/I study. J Clin Oncol. 2019;37(15):1277-84.

431. Jain $N$, Keating $M$, Thompson P, Ferrajoli A, Burger J, Borthakur G, et al. Ibrutinib and Venetoclax for first-line treatment of CLL. N Engl J Med. 2019;380(22):2095-103.

432. de Vos S, Swinnen LJ, Wang D, Reid E, Fowler N, Cordero J, et al. Venetoclax, bendamustine, and rituximab in patients with relapsed or refractory NHL: a phase lb dose-finding study. Ann Oncol. 2018;29(9):1932-8.

433. Seymour JF, Kipps TJ, Eichhorst B, Hillmen P, D'Rozario J, Assouline S, et al. Venetoclax-rituximab in relapsed or refractory chronic lymphocytic leukemia. N Engl J Med. 2018;378(12):1107-20.

434. Cramer P, von Tresckow J, Bahlo J, Robrecht S, Langerbeins P, Al-Sawaf $\mathrm{O}$, et al. Bendamustine followed by obinutuzumab and venetoclax in chronic lymphocytic leukaemia (CLL2-BAG): primary endpoint analysis of a multicentre, open-label, phase 2 trial. Lancet Oncol. 2018;19(9):1215-28

435. Roberts AW, Davids MS, Pagel JM, Kahl BS, Puvvada SD, Gerecitano JF, et al. Targeting BCL2 with Venetoclax in relapsed chronic lymphocytic leukemia. N Engl J Med. 2016;374(4):311-22.

436. Barr PM, Robak T, Owen C, Tedeschi A, Bairey O, Bartlett NL, et al. Sustained efficacy and detailed clinical follow-up of first-line ibrutinib treatment in older patients with chronic lymphocytic leukemia: extended phase 3 results from RESONATE-2. Haematologica. 2018;103(9):1502-10.

437. Byrd JC, Brown JR, O'Brien S, Barrientos JC, Kay NE, Reddy NM, et al. Ibrutinib versus ofatumumab in previously treated chronic lymphoid leukemia. N Engl J Med. 2014;371(3):213-23.

438. Cartron G, de Guibert S, Dilhuydy MS, Morschhauser F, Leblond V, Dupuis J, et al. Obinutuzumab (GA101) in relapsed/refractory chronic lymphocytic leukemia: final data from the phase 1/2 GAUGUIN study. Blood. 2014;124(14):2196-202.

439. Farooqui MZ, Valdez J, Martyr S, Aue G, Saba N, Niemann CU, et al. Ibrutinib for previously untreated and relapsed or refractory chronic lymphocytic leukaemia with TP53 aberrations: a phase 2, single-arm trial. Lancet Oncol. 2015;16(2):169-76.

440. Moreau P, Chanan-Khan A, Roberts AW, Agarwal AB, Facon T, Kumar $\mathrm{S}$, et al. Promising efficacy and acceptable safety of venetoclax plus bortezomib and dexamethasone in relapsed/refractory MM. Blood. 2017;130(22):2392-400.

441. Stilgenbauer S, Eichhorst B, Schetelig J, Coutre S, Seymour JF, Munir T, et al. Venetoclax in relapsed or refractory chronic lymphocytic leukaemia with 17p deletion: a multicentre, open-label, phase 2 study. Lancet Oncol. 2016;17(6):768-78.

442. Stilgenbauer S, Eichhorst B, Schetelig J, Hillmen P, Seymour JF, Coutre S, et al. Venetoclax for patients with chronic lymphocytic leukemia with $17 p$ deletion: results from the full population of a phase II pivotal trial. J Clin Oncol. 2018;36(19):1973-80.

443. Roberts AW, Ma S, Kipps TJ, Coutre SE, Davids MS, Eichhorst B, et al. Efficacy of venetoclax in relapsed chronic lymphocytic leukemia is influenced by disease and response variables. Blood. 2019;134(2):111-22.

444. Konopleva M, Pollyea DA, Potluri J, Chyla B, Hogdal L, Busman T, et al. Efficacy and biological correlates of response in a phase II study of Venetoclax monotherapy in patients with acute myelogenous leukemia. Cancer Discov. 2016;6(10):1106-17.

445. Leverson JD, Sampath D, Souers AJ, Rosenberg SH, Fairbrother WJ Amiot $\mathrm{M}$, et al. Found in translation: how preclinical research is guiding the clinical development of the BCL2-selective inhibitor Venetoclax. Cancer Discov. 2017;7(12):1376-93.

446. Davids MS, Roberts AW, Seymour JF, Pagel JM, Kahl BS, Wierda WG, et al. Phase I first-in-human study of Venetoclax in patients with relapsed or refractory non-Hodgkin lymphoma. J Clin Oncol. 2017;35(8):826-33.
447. Roberts AW, Huang D. Targeting BCL2 with BH3 mimetics: basic science and clinical application of Venetoclax in chronic lymphocytic leukemia and related B cell malignancies. Clin Pharmacol Ther. 2017;101(1):89-98.

448. Ruefli-Brasse A, Reed JC. Therapeutics targeting BCl-2 in hematological malignancies. Biochem J. 2017:474(21):3643-57.

449. Seymour JF, Ma S, Brander DM, Choi MY, Barrientos J, Davids MS, et al. Venetoclax plus rituximab in relapsed or refractory chronic lymphocytic leukaemia: a phase 1b study. Lancet Oncol. 2017;18(2):230-40.

450. Zhang H, Guttikonda S, Roberts L, Uziel T, Semizarov D, Elmore SW, et al. Mcl-1 is critical for survival in a subgroup of non-small-cell lung cancer cell lines. Oncogene. 2011;30(16):1963-8.

451. Xiao Y, Nimmer P, Sheppard GS, Bruncko M, Hessler P, Lu X, et al. MCL-1 is a key determinant of breast Cancer cell survival: validation of MCL-1 dependency utilizing a highly selective small molecule inhibitor. Mol Cancer Ther. 2015;14(8):1837-47.

452. Yecies D, Carlson NE, Deng J, Letai A. Acquired resistance to ABT737 in lymphoma cells that up-regulate MCL-1 and BFL-1. Blood. 2010;115(16):3304-13.

453. Wei SH, Dong K, Lin F, Wang X, Li B, Shen JJ, et al. Inducing apoptosis and enhancing chemosensitivity to gemcitabine via RNA interference targeting Mcl-1 gene in pancreatic carcinoma cell. Cancer Chemother Pharmacol. 2008;62(6):1055-64.

454. Wertz IE, Kusam S, Lam C, Okamoto T, Sandoval W, Anderson DJ, et al. Sensitivity to antitubulin chemotherapeutics is regulated by MCL1 and FBW7. Nature. 2011:471(7336):110-4.

455. Akagi $H$, Higuchi $H$, Sumimoto $H$, Igarashi $T$, Kabashima $A$, Mizuguchi $\mathrm{H}$, et al. Suppression of myeloid cell leukemia-1 (Mcl-1) enhances chemotherapy-associated apoptosis in gastric cancer cells. Gastric Cancer. 2013;16(1):100-10.

456. Thomas RL, Roberts DJ, Kubli DA, Lee Y, Quinsay MN, Owens JB, et al. Loss of MCL-1 leads to impaired autophagy and rapid development of heart failure. Genes Dev. 2013;27(12):1365-77.

457. Vick B, Weber A, Urbanik T, Maass T, Teufel A, Krammer PH, et al. Knockout of myeloid cell leukemia-1 induces liver damage and increases apoptosis susceptibility of murine hepatocytes. Hepatology. 2009:49(2):627-36.

458. Arbour N, Vanderluit JL, Le Grand JN, Jahani-Asl A, Ruzhynsky VA, Cheung $\mathrm{EC}$, et al. MCl-1 is a key regulator of apoptosis during CNS development and after DNA damage. J Neurosci. 2008;28(24):6068-78.

459. Opferman JT, Kothari A. Anti-apoptotic BCL-2 family members in development. Cell Death Differ. 2018;25(1):37-45.

460. Lee EF, Czabotar PE, Yang H, Sleebs BE, Lessene G, Colman PM, et al. Conformational changes in $\mathrm{BCl}-2$ pro-survival proteins determine their capacity to bind ligands. J Biol Chem. 2009;284(44):30508-17.

461. Abulwerdi F, Liao C, Liu M, Azmi AS, Aboukameel A, Mady AS, et al. A novel small-molecule inhibitor of $\mathrm{mcl}-1$ blocks pancreatic cancer growth in vitro and in vivo. Mol Cancer Ther. 2014;13(3):565-75.

462. Ji T, Ding $Y$, Zhao $Y$, Wang J, Qin H, Liu X, et al. Peptide assembly integration of fibroblast-targeting and cell-penetration features for enhanced antitumor drug delivery. Adv Mater. 2015;27(11):1865-73.

463. Soukasene S, Toft DJ, Moyer TJ, Lu H, Lee HK, Standley SM, et al. Antitumor activity of peptide amphiphile nanofiber-encapsulated camptothecin. ACS Nano. 2011;5(11):9113-21.

464. Ben-Nun Y, Fichman G, Adler-Abramovich L, Turk B, Gazit E, Blum G. Cathepsin nanofiber substrates as potential agents for targeted drug delivery. J Control Release. 2017;257:60-7.

465. Zhang P, Cheetham AG, Lin YA, Cui H. Self-assembled tat nanofibers as effective drug carrier and transporter. ACS Nano. 2013;7(7):5965-77.

466. Lin R, Cheetham AG, Zhang P, Lin YA, Cui H. Supramolecular filaments containing a fixed $41 \%$ paclitaxel loading. Chem Commun (Camb). 2013;49(43):4968-70.

467. Chen Z, Xing L, Fan Q, Cheetham AG, Lin R, Holt B, et al. Drug-bearing supramolecular filament hydrogels as anti-inflammatory agents. Theranostics. 2017:7(7):2003-14.

468. Mazza M, Hadjidemetriou M, de Lazaro I, Bussy C, Kostarelos K. Peptide nanofiber complexes with siRNA for deep brain gene silencing by stereotactic neurosurgery. ACS Nano. 2015;9(2):1137-49.

469. Lock LL, Li Y, Mao X, Chen H, Staedtke V, Bai R, et al. One-component supramolecular filament hydrogels as Theranostic label-free magnetic resonance imaging agents. ACS Nano. 2017;11(1):797-805. 
470. Lock LL, Reyes CD, Zhang P, Cui H. Tuning cellular uptake of molecular probes by rational Design of Their Assembly into supramolecular Nanoprobes. J Am Chem Soc. 2016;138(10):3533-40.

471. Li Y, Lock LL, Wang Y, Ou SH, Stern D, Schon A, et al. Bioinspired supramolecular engineering of self-assembling immunofibers for high affinity binding of immunoglobulin G. Biomaterials. 2018;178:448-57.

472. Zhang X, Xu X, Li Y, Hu C, Zhang Z, Gu Z. Virion-like membrane-breaking nanoparticles with tumor-activated cell-and-tissue dual-penetration conquer impermeable cancer. Adv Mater. 2018;30(27):e1707240.

473. Blanco E, Shen H, Ferrari M. Principles of nanoparticle design for overcoming biological barriers to drug delivery. Nat Biotechnol. 2015:33(9):941-51.

474. Newcomb CJ, Sur S, Ortony JH, Lee OS, Matson JB, Boekhoven J, et al. Cell death versus cell survival instructed by supramolecular cohesion of nanostructures. Nat Commun. 2014;5:3321.

475. Schnorenberg MR, Bellairs JA, Samaeekia R, Acar H, Tirrell MV, JL LB. Activating the intrinsic pathway of apoptosis using bim bh3 peptides delivered by peptide amphiphiles with endosomal release. Materials (Basel). 2019;12(16):2567.

476. Missirlis D, Teesalu T, Black M, Tirrell M. The non-peptidic part determines the internalization mechanism and intracellular trafficking of peptide amphiphiles. PLoS One. 2013;8(1):e54611.

477. Acar H, Ting JM, Srivastava S, LaBelle JL, Tirrell MV. Molecular engineering solutions for therapeutic peptide delivery. Chem Soc Rev. 2017;46(21):6553-69.

478. Meyer DE, Kong GA, Dewhirst MW, Zalutsky MR, Chilkoti A. Targeting a genetically engineered elastin-like polypeptide to solid tumors by local hyperthermia. Cancer Res. 2001;61(4):1548-54.

479. Dreher MR, Liu W, Michelich CR, Dewhirst MW, Chilkoti A. Thermal cycling enhances the accumulation of a temperature-sensitive biopolymer in solid tumors. Cancer Res. 2007:67(9):4418-24.

480. Liu W, Dreher MR, Furgeson DY, Peixoto KV, Yuan H, Zalutsky MR, et al. Tumor accumulation, degradation and pharmacokinetics of elastin-like polypeptides in nude mice. J Control Release. 2006;116(2):170-8.

481. Issels RD. Regional hyperthermia combined with systemic chemotherapy of locally advanced sarcomas: preclinical aspects and clinical results. Recent Results Cancer Res. 1995;138:81-90.

482. Feyerabend T, Steeves R, Wiedemann GJ, Richter E, Robins HI. Rationale and clinical status of local hyperthermia, radiation, and chemotherapy in locally advanced malignancies. Anticancer Res. 1997;17(4B):2895-7.

483. van Vulpen M, Raaymakers BW, de Leeuw AA, van de Kamer JB, van Moorselaar RJ, Hobbelink MG, et al. Prostate perfusion in patients with locally advanced prostate carcinoma treated with different hyperthermia techniques. J Urol. 2002;168(4 Pt 1):1597-602.

484. Issels RD. Regional hyperthermia in high-risk soft tissue sarcomas. Curr Opin Oncol. 2008;20(4):438-43.

485. Dinca A, Chien WM, Chin MT. Intracellular delivery of proteins with cellpenetrating peptides for therapeutic uses in human disease. Int J Mol Sci. 2016;17(2):263.

486. Morris MC, Depollier J, Mery J, Heitz F, Divita G. A peptide carrier for the delivery of biologically active proteins into mammalian cells. Nat Biotechnol. 2001;19(12):1173-6.

487. Schwarze SR, Ho A, Vocero-Akbani A, Dowdy SF. In vivo protein transduction: delivery of a biologically active protein into the mouse. Science. 1999;285(5433):1569-72.

488. Cao G, Pei W, Ge H, Liang Q, Luo Y, Sharp FR, et al. In vivo delivery of a $\mathrm{BCl}-\mathrm{XL}$ fusion protein containing the TAT protein transduction domain protects against ischemic brain injury and neuronal apoptosis. J Neurosci. 2002;22(13):5423-31

489. Andreev OA, Engelman DM, Reshetnyak YK. Targeting acidic diseased tissue: new technology based on use of the $\mathrm{pH}$ (low) insertion peptide (pHLIP). Chim Oggi. 2009;27(2):34-7.

490. Andreev OA, Engelman DM, Reshetnyak YK. pH-sensitive membrane peptides (pHLIPs) as a novel class of delivery agents. Mol Membr Biol. 2010;27(7):341-52.

491. Deacon JC, Engelman DM, Barrera FN. Targeting acidity in diseased tissues: mechanism and applications of the membrane-inserting peptide, pHLIP. Arch Biochem Biophys. 2015;565:40-8.
492. Banerjee A, Onyuksel H. Peptide delivery using phospholipid micelles. Wiley Interdiscip Rev Nanomed Nanobiotechnol. 2012;4(5):562-74.

493. Guo J, Wu T, Ping Q, Chen Y, Shen J, Jiang G. Solubilization and pharmacokinetic behaviors of sodium cholate/lecithin-mixed micelles containing cyclosporine a. Drug Deliv. 2005;12(1):35-9.

494. Onyuksel H, Jeon E, Rubinstein I. Nanomicellar paclitaxel increases cytotoxicity of multidrug resistant breast cancer cells. Cancer Lett. 2009;274(2):327-30.

495. Lim SB, Rubinstein I, Sadikot RT, Artwohl JE, Onyuksel H. A novel peptide nanomedicine against acute lung injury: GLP-1 in phospholipid micelles. Pharm Res. 2011;28(3):662-72.

496. Krishnadas A, Onyuksel H, Rubinstein I. Interactions of VIP, secretin and PACAP(1-38) with phospholipids: a biological paradox revisited. Curr Pharm Des. 2003;9(12):1005-12.

497. Onyuksel H, Sejourne F, Suzuki H, Rubinstein I. Human VIP-alpha: a longacting, biocompatible and biodegradable peptide nanomedicine for essential hypertension. Peptides. 2006;27(9):2271-5.

498. Kuzmis A, Lim SB, Desai E, Jeon E, Lee BS, Rubinstein I, et al. Micellar nanomedicine of human neuropeptide $Y$. Nanomedicine. 2011;7(4):464-71.

499. Banerjee A, Onyuksel H. Human pancreatic polypeptide in a phospholipid-based micellar formulation. Pharm Res. 2012;29(6):1698-711.

500. Reubi JC. Peptide receptors as molecular targets for cancer diagnosis and therapy. Endocr Rev. 2003;24(4):389-427.

501. Liu S, Pan J, Liu J, Ma Y, Qiu F, Mei L, et al. Dynamically PEGylated and borate-coordination-polymer-coated Polydopamine nanoparticles for synergetic tumor-targeted, Chemo-Photothermal Combination Therapy. Small. 2018;14(13):e1703968.

502. Choi JY, Gupta B, Ramasamy T, Jeong JH, Jin SG, Choi HG, et al. PEGylated polyaminoacid-capped mesoporous silica nanoparticles for mitochondria-targeted delivery of celastrol in solid tumors. Colloids Surf B Biointerfaces. 2018;165:56-66.

503. Tomoda K, Chiang HC, Kozak KR, Kwon GS. Injectable (-)-gossypolloaded Pluronic P85 micelles for cancer chemoradiotherapy. Int J Radiat Biol. 2017:93(4):402-6.

504. Tomoda K, Chiang C, Kozak KR, Kwon GS. Examination of gossypol-Pluronic micelles as potential Radiosensitizers. AAPS J. 2015;17(6):1369-75.

505. Chen S, Ren Y, Duan P. Biomimetic nanoparticle loading obatoclax mesylate for the treatment of non-small-cell lung cancer (NSCLC) through suppressing $\mathrm{Bcl}-2$ signaling. Biomed Pharmacother. 2020;129:110371.

506. Oakes SA, Scorrano L, Opferman JT, Bassik MC, Nishino M, Pozzan T, et al. Proapoptotic BAX and BAK regulate the type 1 inositol trisphosphate receptor and calcium leak from the endoplasmic reticulum. Proc Natl Acad Sci U S A. 2005;102(1):105-10

507. Maiuri MC, Criollo A, Tasdemir E, Vicencio JM, Tajeddine N, Hickman $\mathrm{JA}$, et al. $\mathrm{BH} 3$-only proteins and $\mathrm{BH} 3$ mimetics induce autophagy by competitively disrupting the interaction between Beclin 1 and $\mathrm{BCl}-2 /$ BCl-X(L). Autophagy. 2007;3(4):374-6.

508. Pedro JM, Wei Y, Sica V, Maiuri MC, Zou Z, Kroemer G, et al. BAX and BAK1 are dispensable for ABT-737-induced dissociation of the BCL2BECN1 complex and autophagy. Autophagy. 2015;11(3):452-9.

509. Koehler BC, Scherr AL, Lorenz S, Elssner C, Kautz N, Welte S, et al. Pan-Bcl-2 inhibitor obatoclax delays cell cycle progression and blocks migration of colorectal cancer cells. PLoS One. 2014;9(9):e106571.

510. Zhong D, Gu C, Shi L, Xun T, Li X, Liu S, et al. Obatoclax induces G1/ G0-phase arrest via p38/p21 (waf1/Cip1) signaling pathway in human esophageal cancer cells. J Cell Biochem. 2014;115(9):1624-35.

\section{Publisher's Note}

Springer Nature remains neutral with regard to jurisdictional claims in published maps and institutional affiliations. 